\title{
Project Closeout Report for the MFC Firewater Replacement Project
}

Project Number: 31780

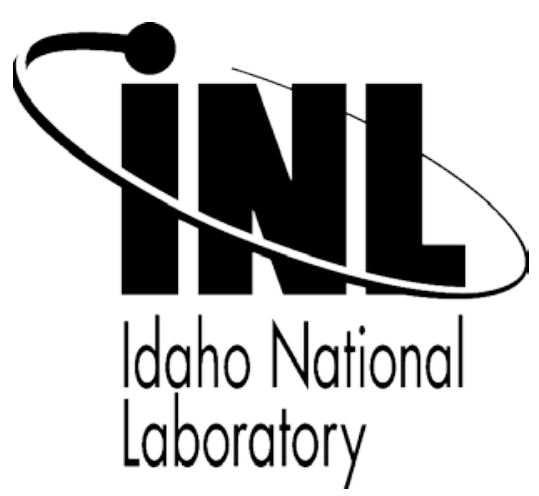





\section{DISCLAIMER}

This information was prepared as an account of work sponsored by an agency of the U.S. Government. Neither the U.S. Government nor any agency thereof, nor any of their employees, makes any warranty, expressed or implied, or assumes any legal liability or responsibility for the accuracy, completeness, or usefulness, of any information, apparatus, product, or process disclosed, or represents that its use would not infringe privately owned rights.

References herein to any specific commercial product, process, or service by trade name, trade mark, manufacturer, or otherwise, does not necessarily constitute or imply its endorsement, recommendation, or favoring by the U.S. Government or any agency thereof. The views and opinions of authors expressed herein do not necessarily state or reflect those of the U.S. Government or anv agencv thereof. 
Project Closeout Report for the MFC Firewater Replacement Project

Project Number: 31780

INL/EXT-16-38154

June 2016

Reviewed by:

Zane Mickelsen

Zane Mickelpen

Project Manager

Approved by:

Stuart Jensen Approved Via Email

S. Jensen

MFC Engineering Director

$\frac{\text { Bob Milos A frond via Email }}{\text { R. Miklos }}$

MFC Production Facilities Director $\frac{6 / 20 / / 6}{\text { Date }}$

$\frac{6 / 20 / 16}{\text { Date }}$

iv 


\section{EXECUTIVE SUMMARY}

The Material and Fuels Complex (MFC) Firewater Replacement Project was an indirectly funded Institutional General Plant Project (IGPP) capital acquisition initiated in July 2013 and completed in June 2016. Its purpose was to improve the capacity, redundancy and reliability of the MFC fire water and potable water systems, making them compliant with DOE O 420.1C and applicable state and federal regulations. The individual sub-systems are collectively referred to as the MFC Firewater System. Key performance parameters (KPPs) for modifying or constructing new structures, systems, and components (SSCs) in the MFC Firewater System and demolishing old, obsolete SSCs were all completed and are summarized as follows.

- A new pump house facility (MFC-1740) was constructed. The pump house contains heating and ventilation systems, a new mixed oxide (MIOX) water treatment system, diesel-powered fire water pump, and four potable water pumps.

- A new welded steel 400,000 gallon fire water storage tank was designed, fabricated, installed and integrated with the new pump house and fire water loop.

- Controls for the pump house, systems and components were installed and integrated with the existing MFC Firewater Control System.

- Over a mile of trenching and pipe installation created a new fire water loop line from MFC to the TREAT Area, including installation and connection of a new fire water loop within the TREAT control area fence.

- An obsolete fuel oil pump house (MFC-755) was demolished and the underground piping and concrete pad were abandoned in place. The old fuel oil tanks and foundations (MFC-755A and MFC-755B) were demolished.

- The existing, obsolete 200,000 gallon fire water tank and foundation (MFC754A) were demolished.

Total project cost (TPC) was estimated at $\$ 9,483 \mathrm{~K}$, which included $\$ 250 \mathrm{~K}$ of contingency and $\$ 689 \mathrm{~K}$ of management reserve. Risks related to underground interferences, unexpectedly large basalt deposits, and required design changes were realized. As a result, $\$ 501 \mathrm{~K}$ of management reserve was allocated during the project execution phase. None of the contingency funds were needed and $\$ 189 \mathrm{~K}$ of management reserve was unallocated. The project was completed for $\$ 8829 \mathrm{~K}$, with positive cost variance of $\$ 215 \mathrm{~K}(\mathrm{CPI}=1.02)$. Schedule performance ranged between .99 and 1.01 throughout the duration of the performance measurement baseline with the exception of three months that dropped to a range of .91 to .95. Specific, significant accomplishments included:

- Surmounted multiple realized risks to submit the CDE-4 package ahead of schedule and under budget.

- Completed all KPPs without notable safety or environmental incident.

- Eliminated 16,850 square feet of unneeded footprint by demolishing an unserviceable firewater tank and antiquated fuel oil pump house and tanks. 
- $\quad$ Executed a buy-down strategy to procure piping and demolish the old fuel oil pump house and tanks prior to award of the main contract, which leveled project costs across fiscal years and accelerated the start of construction.

- Re-bid the construction contract with a wider group of potential contractors, improving competition and bringing the awarded contract value closer in line with project estimates.

- Coordinated schedules with the Resumption of Transient Testing Program, installing fiber optic cable while the firewater trench was open. This shortened the TREAT re-start schedule and reduced costs for re-trenching and cable installation.

In summary, the project successfully upgraded the MFC Firewater System's capacity, redundancy, and reliability. The project was completed ahead of schedule and under budget, despite realization of significant risks. Value to the government was optimized by the procurement strategy and by coordination with activities supporting TREAT re-start. The MFC Firewater System is now fully compliant with DOE O 420.1C requirements and applicable regulations. 


\section{CONTENTS}

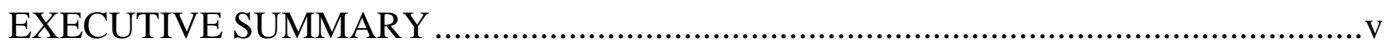

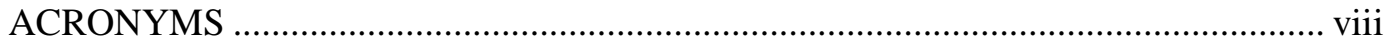

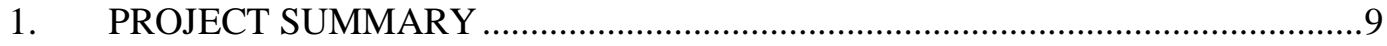

1.1 Summary of the Final Project Scope \& Deliverables..................................12

1.1.1 Technical, Cost, and Schedule Baseline Accomplishments .............13

1.1.2 Significant Changes to the Project Baseline ....................................13

1.2 Open Items Required to Complete the Project .............................................14

1.3 Permits, Licenses, Environmental Documentation Generated ......................14

1.4 Warranties and Service Contracts Maintained by the Customer/Facility

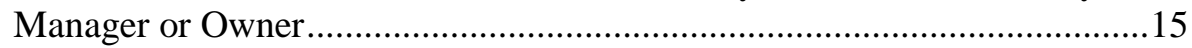

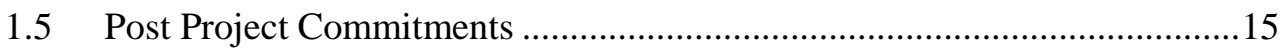

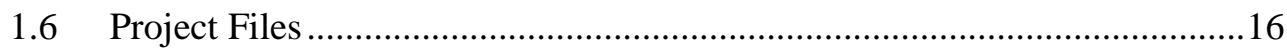

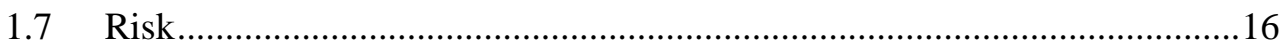

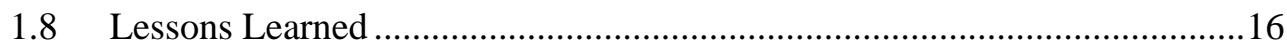

1.9 Final Cost Report and Financial Closeout Status .......................................16

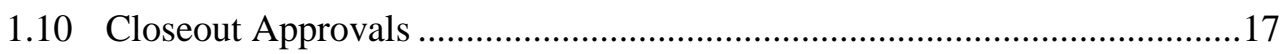

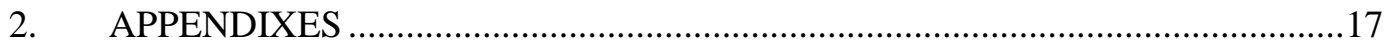

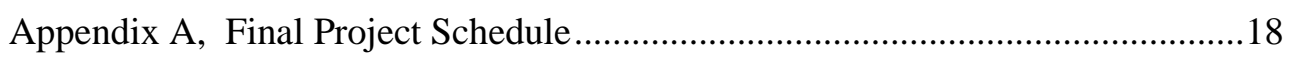

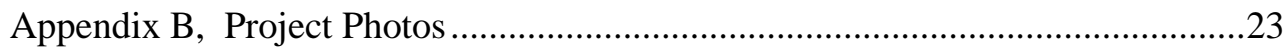

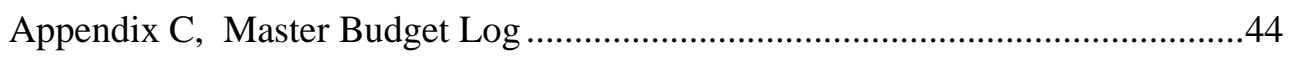

Appendix D, Project Deficiency Punchlist ....................................................50

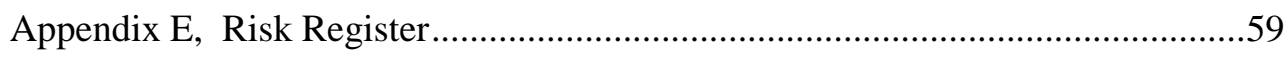

Appendix F, Lessons Learned Report............................................................61

Appendix G, Final Project Transfer ..............................................................66

Appendix H, Project Acceptance/Turnover Plan...............................................70

Appendix I, Executed Transition to Operations Final Turnover Checklist............79

Appendix J, Idaho Department of Environmental Quality Final Project Approval 


\section{ACRONYMS}

$\begin{array}{ll}\text { AE } & \text { Acquisition Executive } \\ \text { BCP } & \text { baseline change proposal } \\ \text { BEA } & \text { Battelle Energy Alliance, LLC } \\ \text { CD } & \text { critical decision } \\ \text { CDE } & \text { critical decision equivalent } \\ \text { CDR } & \text { Conceptual Design Report } \\ \text { DOE } & \text { U.S. Department of Energy } \\ \text { DOE-ID } & \text { U.S. Department of Energy Idaho Operations Office } \\ \text { F\&ORs } & \text { Functional and Operational Requirements } \\ \text { FPD } & \text { Federal Project Director } \\ \text { FY } & \text { fiscal year } \\ \text { GIO } & \text { General Plant Projects (GPP), Institutional General Plant Projects } \\ \text { IGPP } & \text { IGPP), and Operating Funded Construction Projects (OFP) } \\ \text { INL } & \text { Institutional General Plant Project } \\ \text { KPP } & \text { Idaho National Laboratory } \\ \text { MIOX } & \text { Key Performance Parameter } \\ \text { MFC } & \text { mixed oxide water treatment } \\ \text { TREAT } & \text { Materials and Fuels Complex } \\ \text { WBS } & \text { Transient Reactor Test } \\ & \text { work breakdown structure }\end{array}$




\section{Project Closeout Report for the MFC Firewater Replacement Project}

\section{PROJECT SUMMARY}

The MFC Firewater Replacement Project was an indirectly funded Institutional General Plant Project (IGPP) for capital acquisition of upgraded fire water and potable water systems at the Material and Fuels Complex (MFC). The purpose of this project was to improve the capacity, redundancy and reliability of the MFC Firewater System, making it compliant with DOE O 420.1C and with applicable state and federal regulations.

Fire water service and potable water service are integrated at MFC, and are collectively referred to as the MFC Firewater System. The Firewater System supplies both firewater and potable water services to MFC and to the Transient Reactor Test (TREAT) Area, which is located approximately half a mile to the northwest of MFC. The fire water tanks, pumps, controls and pump houses are located within MFC and were constructed or upgraded by the project. The supply lines to the TREAT Area were replaced with a piping loop to provide a redundant supply to the area, and to increase reliability and supply capacity. Potable water supplies to the TREAT Area were also upgraded. The project included demolition of an obsolete fuel oil tank system to make space for a new fire water tank and demolition of an old fire water tank that was no longer serviceable.

Delivery of the project is discussed below by project phase:

\section{Project Definition:}

A formal mission need document was not formulated for this project. Equivalent approval of critical decision (CD)-0, Approve Mission Need, was obtained via DOE approval of the Idaho National Laboratory (INL) 2015-2025 Ten-Year Site Plan consistent with the GIO process defined in Appendix E of MCP-7001(A “GIO” Project is a General Plant Project (GPP), Institutional General Plant Project (IGPP), or Operating-Funded Construction Project (OFP).). Project definition began in July 2013 with approval of baseline change proposal (BCP) IN-13-163 and changes to the baseline from that point forward are summarized in Section 1.1.2. During project definition, design requirements were developed to provide the basis for advanced planning, cost estimating, schedules, and scope definition, including:

- Development of functional and operational requirements (F\&ORs)

- Technical evaluations

- Design requirements

- Preliminary drawings

- Safety evaluations

- Quality level determination

- Class 5 cost estimate

- Project schedule

- Davis Bacon and Funding determinations

- Environmental checklist

As an indirectly funded project, the MFC Firewater Replacement Project was incrementally funded on an annual basis. This resulted in an acquisition strategy that combined early buy-down of piping, new tank materials and demolition services with a design-bid-build approach for the major construction contract. After the relevant specifications were developed, early buy-down of selected scope was selected as a procurement strategy because it allowed use of well established, standard industrial specifications and practices that were not expected to change during final design. Title design was completed in-house in January 2015. The cost estimate was updated and the procurement process was initiated.

Two bid proposals were received in early March 2015 from the solicitation; neither of which aligned with the project estimates. A second solicitation, open to large businesses, was released with thirteen 
bidders identified. The increased competition and construction methods available to large businesses is believed to have been a contributing factor in providing a range of proposals that were closer in line with the project estimates. The contract was awarded to North Wind Services, LLC on April 21, 2015.

\section{Project Execution:}

Because of the procurement delay for a second solicitation and its impact on the construction schedule, the Acquisition Executive (AE) authorized the start of construction on May 21, 2015 (IFM-15014) within the constraints of the existing, bounding baseline, but without critical decision equivalent (CDE)-2/3 approval. Construction started on June 1, 2015. The PMB and CDE-2/3 package were assembled and submitted (CCN 235942), although approval of CDE-2/3 was deferred for extended comment resolution. The original construction completion date was retained, as were the existing variances as directed by the acquisition executive (AE) (CCN 236026). The revised CDE-2/3 package was re-submitted (CCN 236141) and approved as submitted (CCN 236196), establishing the PMB as detailed in Table 1 below.

Table 1: Total Project Cost estimated for the MFC Firewater Replacement Project at CDE-2/3

\begin{tabular}{|l|r|r|r|}
\hline \multicolumn{1}{|c|}{ Description } & \multicolumn{1}{c|}{$\begin{array}{c}\text { Total } \\
\text { Estimated } \\
\text { Costs (TEC) }\end{array}$} & $\begin{array}{r}\text { Other } \\
\text { Project } \\
\text { Costs (OPC) }\end{array}$ & \multicolumn{1}{c|}{ Total } \\
\hline Performance Measurement Baseline & $\mathbf{\$ 8 , 1 4 1 , 3 6 4}$ & $\mathbf{\$ 4 0 2 , 4 9 0}$ & $\mathbf{\$ 8 , 5 4 3 , 8 5 4}$ \\
\hline CD-1 and CD-2/3 Development \& Approval & & $\$ 200,000$ & \\
\hline Fire Water System & $\$ 4,518,373$ & $\$ 24,343$ & \\
\hline Fire Water Line & $\$ 2,665,142$ & $\$ 18,932$ & \\
\hline D\&D Fuel Oil Tanks & & $\$ 22,200$ & \\
\hline Fuel Oil Tanks & $\$ 579,573$ & & \\
\hline Project Management & $\$ 378,276$ & $\mathbf{\$ 1 1 , 5 6 1}$ & \\
\hline Project Turnover/Closeout & & $\$ 125,454$ & \\
\hline Management Reserve & $\mathbf{\$ 6 4 3 , 7 6 7}$ & $\mathbf{\$ 4 5 , 0 0 0}$ & $\mathbf{\$ 6 8 8 , 7 6 7}$ \\
\hline \hline Contract Budget Base (CBB) & $\mathbf{\$ 8 , 7 8 5 , 1 3 1}$ & $\mathbf{\$ 4 4 7 , 4 9 0}$ & $\mathbf{\$ 9 , 2 3 2 , 6 2 1}$ \\
\hline Contingency & $\mathbf{\$ 2 5 0 , 0 0 0}$ & & \\
\hline \hline Total & $\mathbf{\$ 9 , 0 3 5 , 1 3 1}$ & $\mathbf{\$ 4 4 7 , 4 9 0}$ & \\
\hline Total Project Cost (TPC) & & & $\mathbf{\$ 9 , 4 8 2 , 6 2 1}$ \\
\hline
\end{tabular}

Estimated costs presented in Table 1 were based on cost estimate (WES-EST-15-096), which was updated based on actual costs at CDE-2/3, the updated final design and the construction bid.

Approximately $10 \%$ of the contract value was planned as anticipated contract change requests. Internal and external activity completion dates and project milestones were established at CDE-2/3 approval as follows, where the activity identification numbers correspond to the project schedule contained in Appendix A.

- Start New Tank Construction Milestone

- New Tank Construction Complete Milestone

- Start New Pump House Construction Milestone

- New Pump House Construction Complete Milestone

- $\quad$ Pipeline - FWL (Start/Finish)

- Construction Complete Milestone

- Turnover/Startup and Closeout
24-Jun-15

30-Sep-15

30-Jun-15

13-Oct-15

23-Jun-15/22-Sep-15

30-Nov-15

1-Dec-15/19-Jan-16 
As noted, construction started on June 1, 2015 with mobilization activities - the progression of construction is illustrated in Appendix B. Significant portions of the work were planned with six-day work weeks to maintain the construction completion date of November 30, 2015. Work started on the new 400,000 gallon tank and pump house foundations with excavation and footings. Excavation inside the MFC fence to make piping connections was performed by vacuum extraction and the majority of the pipeline trenching inside and between the MFC fences was performed with vacuum extraction due to the close quarters and some uncertainty in underground piping configurations. Underground interferences were encountered (Risk Register \#6), but were addressed by vacuum excavation and minor design changes within the budget for change orders and without impact to the overall schedule.

Trenching between MFC and TREAT was performed in July and August with a rock trencher, and encountered a significant amount of basalt (Risk Register \#2). Trenching was planned with float in the schedule as a risk mitigation measure, and an additional trencher was used on the south portion of the loop to prevent affecting the critical path. Costs were maintained within the budget for contract change orders. The 14-inch HDPE piping was assembled and placed in the trench as the major portions of the trench were completed. Backfill of the trenching was delayed to allow the Resumption of Transient Testing Program (RTTP) to lay fiber optic and coaxial cables in segments of the north trench. This did not affect the overall project schedule and avoided substantial trenching costs for the RTTP.

Permanent fire water and potable water connections were started inside MFC and at the TREAT area in late August and early September. The piping configurations inside TREAT were not as expected and considerably more rock cutting was needed, in part because of the piping configuration and also in part because additional basalt was discovered (Risk Register \#2 and \#6). The extent of condition was investigated using vacuum extraction and an additional rock cutter was employed. Additionally, finishing the trenching and piping with the TREAT fence replaced the electrical and mechanical work in the pump house as the critical path for completion of the construction.

Incremental discovery of additional basalt during vacuum extraction resulted in additional rock cutting, piping configuration design changes and schedule delays. The cumulative costs for those activities, as well as the additional costs of maintaining temporary services during the activities, required the allocation of management reserve and eventually resulted in a contract change that deferred the completion of construction to December 31, 2015. Deferral of the construction completion milestone used one month of schedule reserve baselined in June 2016. Associated change control documents are referenced in Section 1.1.2.

The new 400,000 gallon tank and the pump house were substantially erected in July and August. The tank was sandblasted in August and primed in September. Painting inside the tank was completed and insulation work inside and outside the tank started and continued through early fall. Electrical work in the pump house started in September, representing the critical path until the delays associated with trenching and piping in the TREAT Area replaced it. The fire water pump skid was received in September and tieins to the existing control system started in October. The mixed oxide water treatment (MIOX) system installation started in October and completed in November. Control system programming, fire water pump alignment and development of operating instructions were completed in November and early December. However, difficulty in integrating the deep well pump controls with the new fire water system controls and scheduling conflicts for vendor support resulted in a decision to defer training and partial turnover until January. As a result, the construction completion milestone was missed but operational certainty was improved by avoiding implementation of new procedures over the December curtailment.

Final system testing was started in January and an air vent was installed on the discharge of the diesel fire water pump to eliminate the risk of water surge. Minor adjustments were made, but no significant 
issues were identified and partial turnover was commenced. During partial turnover, the design requirements regarding lead content in some of the diesel-powered fire water pump components were questioned. After evaluation, it was confirmed that Safe Drinking Water Act requirements apply to the fire water pump because it can be connected to the potable water system and those requirements were not adequately implemented in the design. The pump impeller shaft sleeve and wear rings were replaced with lead-free components and testing resumed in March 2016.

The firewater pump was isolated from the rest of the system since its installation and there was no risk to the MFC or TREAT Area potable water supplies at any time. Water samples confirmed that the lead content in the system was non-detectable at the time of discovery, during evaluation and component replacement, and prior to placing the system in service.

After testing, partial turnover of the fire water system to Operations was completed on April 7, 2016. The new system was placed in service and the old 400,000 gallon tank and pump house taken out of service for inspection and replacement of leaky valves. Work on the old system was completed and returned to service, followed by completion of the System Operability Test, final punch list items and project close-out.

Project close-out was started in December 2015 in parallel with final construction activities to the extent possible in order to complete as much of the work as possible in parallel. Conversion of as-built drawings, development of operating and maintenance procedures, and update of the design basis were performed off the critical path to maintain the date for submission of the CDE-4 package to DOE-ID. An Operations and Maintenance manual along with the as-built design was submitted (CCN 238138) to the Idaho Department of Environmental Quality (DEQ) and on May 4, 2016, DEQ provided final project approval (CCN 238230) which can be found in Appendix I.

Other significant activities that occurred off the critical path were the demolition of the old 200,000 gallon tank and punch list work such as painting, caulking and grouting. Demolition of the 200,000 gallon tank was performed in October and November. Asbestos was encountered (Risk Register \#7) but properly identified and disposed of without incident. Injection of concrete under a void under the old pump house and reconstruction of the back wall were completed without affecting the critical path.

\subsection{Summary of the Final Project Scope \& Deliverables}

The project delivered upgraded, reliable, redundant and compliant fire water and potable water systems for MFC and the TREAT Area. The project completed all Key Performance Parameters (KPPs) which spanned the planning, design, procurement, construction, startup, acceptance testing, and project closeout for new structures, systems, and components (SSCs) and modifications to existing SSCs as follows:

- Demolition of the MFC-755 Fuel Oil Pump House and earth berms.

- Demolition of the MFC-755A \& MFC-755B 60,000- and 100,000-gallon fuel oil tanks and foundations.

- Abandonment- in- place of the MFC-755 Fuel Oil Pump House concrete slab, foundation, CERCLA injection well, underground fuel oil lines between the MFC-755 and MFC-768 power plant, and underground electrical and communications conduit duct banks. Removal of these systems and services was not included in the project work scope.

- Demolition of the MFC-754A 200,000 gallon water tank.

- Installation of a new fire water loop line from MFC to TREAT.

- Installation of a new fire water loop within the TREAT control area fence.

- Installation of a new welded steel 400,000 gallon fire water storage tank.

- Installation of a new water treatment system. 
- Construction of a new pump house facility (including heating and ventilation systems), which will house the new diesel fire water pump, four potable/fire water pumps, and controls.

- Demonstration of system performance requirements were met by performance of a system operability test.

\subsubsection{Technical, Cost, and Schedule Baseline Accomplishments}

Significant accomplishments are described below.

- The CDE-4 package was submitted slightly ahead of schedule, at which time the project actual total costs were $\$ 215 \mathrm{~K}$ less than the budget at completion.

- At CDE-4 submittal, the project cost and schedule variances were within established thresholds $(\mathrm{CPI}=1.02 \& \mathrm{SPI}=1.00)$.

- The project met all defined technical, functional and operational requirements, as verified through design review, inspection and quality control during construction, and documented facility turnover;

- All key performance parameters were completed as defined in the project execution plan (PEP).

- The project affected a successful buy-down strategy to procure piping and demolish the old fuel oil tanks prior to execution of the main contract. This leveled costs across fiscal years and accelerated the start of construction once CDE-2/3 was approved.

- The project eliminated 16,850 square feet of unneeded footprint by demolishing the old 200,000 gallon tank and the antiquated fuel oil pump house and fuel oil tanks.

- The project successfully re-bid the construction contract with a wider group of potential contractors, improving competition and reducing the original lowest bid by approximately $\$ 2.2 \mathrm{M}$.

- The project successfully coordinated schedules with the TREAT re-start, allowing installation of fiber optic cable in the Firewater trench while it was open. This coordination avoided the cost of re-trenching under the RTTP Program.

- $\quad$ The project upgraded the MFC and TREAT Area potable water systems;

- The project upgraded the MFC Firewater System capacity, redundancy, and reliability. The system is now fully compliant with DOE O 420.1C requirements and applicable regulations.

\subsubsection{Significant Changes to the Project Baseline and Performance Measurement Baseline}

\section{Project Baseline}

The project was initiated in July 2013 with approval of BCP IN-13-163, authorizing the development of Functional and Operational Requirements (F\&ORs), a conceptual design, and a Class 5 cost estimate. After the F\&ORs were developed, conceptual design and a Class 5 estimate were completed; then the project was placed on hold due to indirect funding shortfalls.

The project was re-started in June 2014 with approval of BCP IN-14-132, authorizing Title Design and revision of the cost estimate, materials buy-down, and further planning. In July 2014 and August 2014, respectively, BCP IN-14-159 and BCP IN-14-161 converted planning packages into baseline activities for project buy-down of the Fuel Oil Tank demolition, fabrication of a new 400,000 gallon tank, and procurement of firewater loop piping.

BCP-15-003 revised the baseline to reflect changes to the INL business model, including rate changes, in October 2014. In November, BCP IN-15-036 was approved to align planning package dates 
with the expected completion of Title Design. After completing Title Design, BCP IN-15-084 was approved in February 2015 to convert planning packages into specific procurement activities supporting release of the Request for Proposal (RFP). The first responses to the RFP were inconsistent with the INL cost estimate, and re-issue of the RFP led to award of the construction contract to North Wind Services, LLC on 4/21/2015. BCP IN-15-147 was approved in May 2015 to align construction planning packages with the revised expectations for the construction period in the contract. BCP IN-15-185 was approved in July 2015 to re-schedule planning packages because of delayed CDE-2/3 approval.

\section{Performance Measurement Baseline}

Following CDE-2/3 approval, BCP IN-15-186 was approved to establish the Performance Measurement Baseline through the Execution Phase of the project.

BCP IN-16-002 was approved October 2015 to convert planning packages to detailed work packages, enabling testing, turn-over and close-out activities to start earlier than originally planned. Realization of execution risks led to utilization of management and schedule reserve in BCP IN-16-050 (November 2015) and BCP IN-16-089 (January 2016). The transmittal date for the CDE-4 package was changed to June 14, 2016, but the completion date for the project remained unchanged, as did the contract budget base. The cumulative effect of the BCPs in FY2016 was use of $\$ 501 \mathrm{~K}$ of management reserve and an increase in the budget at completion (BAC) to \$9,044K. A Master Budget Log, contained in Appendix C, was used to capture the budget impact of each BCP.

\subsection{Open Items Required to Complete the Project}

There are no open items on the deficiency punch-list (see Appendix D) at the time of project closeout related to the MFC Firewater Replacement Project. Scope that was added to the contract to support the Resumption of Transient Test Program or to investigate leaks in the MFC Firewater System, unrelated to this project, was added under separate CFPs. Costs were maintained separately and at the time of project close-out there were no open items related to these CFPs.

All essential as-built drawings and vendor data submittals are complete and there are no pending lawsuits or warranty claims.

\subsection{Permits, Licenses, Environmental Documentation Generated}

Environmental Checklist INL-14-062 was developed to identify potential environmental concerns associated with the project and resulted in a Categorical Exclusion determination. All requirements of the Environmental Checklist were implemented during the project and have been completed. Discussions of the most significant project-related environmental activities follow:

Air Permitting Applicability Determination (APAD) INL-15-011 documents that the diesel-powered fire water pump qualifies for a Category II exemption for construction and permitting per IDAPA 58.01.01.22, but does require compliance with the Title V Tier I Operating Permit. Controls are established in fuel procurement documents and operating instructions, but there are no limitations on the hours of emergency operation.

Trenching across the north and south sections of the MFC interceptor canal and mounds (Institutional Control Areas ANL-01 and ANL-09), removed previously remediated CERCLA (OU 9-04) soils. Sample results taken prior to trenching were below the $23.3 \mathrm{pCi} / \mathrm{g}$ remediation goal (MFC Analytical Laboratory Log \#98776 and Log \#98893). Hence, no extraordinary soil disposal requirements were required and the soils were placed back in the trench. 
During August 2015, the Northwind Construction Services, LLC obtained permission from the construction field representative and security to waste their trench soil tailings in the Wastewater Ditch C which is permitted for reverse osmosis, industrial and storm water waste discharges under permit (WRUI-0160-01). Ditch C was not identified as part of the environmental checklist. On August 6, 2015, a person from the environmental support group was performing plant inspections and noticed the tailings being applied to the ditch. Northwind was directed to stop placing soil tailings in the ditch and a fact finding meeting was conducted. DOE-ID and the Idaho DEQ were notified of the disturbance and a formal notification letter was transmitted to Idaho DEQ on August 12, 2015. Northwind was directed to formally suspend any further soil disposal in Ditch $\mathrm{C}$ and complete restoration of the ditch. On October 22, 2015 Idaho DEQ performed and inspection to review the system. During the inspection debriefing Idaho DEQ inspectors stated that there were no violations noted during the inspection and accepted that the ditch would be restored within the next four weeks. On November 19, 2015, Northwind completed the restoration of Ditch C and a formal notification letter was issued to Idaho DEQ stating that Ditch C was reconstructed.

As required by IDAPA 58.01.08, drinking water plans and specifications (system design) were provided to Idaho DEQ (PWS\#6060036, Drinking Water, DEQ\#15-01-12) and approved prior to construction (CCN235324). One variance was requested from IDAPA 58.01.08.547.02.b.iii.(1).(b) to approve a 9 foot sleeve (versus a 10 foot sleeve) on one side of a potable water supply line in the TREAT Area, as it passes an existing sewer line, due to physical constraints (CCN 237233). The variance was granted, in part due to infrequent use of the sewer line and because the sewer is encased in concrete (CCN 237307). Extension of the one-year construction approval beyond February 26, 2015 was requested and granted (CCN237746). The fire water system as a whole must comply with NSF 372 "Drinking Water System Components - Lead Content," and it was discovered that components in the firewater pump assembly had lead content that exceeded these requirements. As a result, the fire water pump shaft sleeve and wear rings were replaced with lead-free components which reduced the weighted-average lead content of the firewater pump assembly for compliance with "Reduction of Lead in Drinking Water Act" Section 1417 (ECAR 3205). The firewater pump was isolated before and when the condition was discovered, and water samples taken upon discovery and until the components were replaced confirmed that lead concentrations in the MFC-1740 water supply were non-detectable. The confirmatory sample reports are contained in the project record.

For the purposes of environmental compliance, the completion of construction defined by the turnover to Operations was accomplished on April 7, 2016. Transmittal of the Maintenance and Operations (M\&O) Manual, and associated drawings to Idaho DEQ was required within 30 days of that date. Those documents were transmitted to Idaho DEQ on April 28, 2016 (CCN 238138). Idaho DEQ provided final project approval on May 4, 2016 (CCN 238230).

\subsection{Warranties and Service Contracts Maintained by the Customer/Facility Manager or Owner}

Warranties associated with the materials and services provided in this project are defined in the contract documents. The applicable contract with warranty considerations are defined below.

- Construction Subcontract 154606: Warrantied for one year from the date of partial or final acceptance of work (see contract documents for details).

\subsection{Post Project Commitments}

There are no incomplete post project commitments. 


\subsection{Project Files}

A complete listing of project records and facility configuration information is available within the project files for the project. The documentation listed in the project files can be obtained from EDMS. Vendor data from the construction subcontracts can be obtained from the INL vendor data system. Vendor data schedule numbers are provided in Table 1.

Table 1: Vendor Data Schedule

\begin{tabular}{|l|r|r|}
\hline \multicolumn{1}{|c|}{ Contract } & \multicolumn{1}{c|}{ Contract \# } & \multicolumn{1}{c|}{ Vendor Data Schedule \# } \\
\hline HDPE Pipe Procurement & N/A & $31780-466842$ \\
\hline MFC Firewater Storage Tank & 148973 & $31780-474472$ \\
\hline $\begin{array}{l}\text { MFC Firewater Tank and Pump House } \\
\text { Construction }\end{array}$ & 154606 & $31780-484738$ \\
\hline MFC Firewater Underground Piping & 154606 & $31780-484881$ \\
\hline
\end{tabular}

A search for documents related to this project can also be performed using EDMS and project \#31780.

\subsection{Risk}

A complete listing of the project risks, risk mitigation strategies, and risk results was included in the PEP. The most current revision of the PEP can be referenced on the Electronic Document Control System (EDMS) as PLN-4866 Rev.2, dated 7/22/2015. The risk register, as it appeared in PLN-4866 Rev. 2 at CDE-2/3 approval, is presented in Appendix E.

\subsection{Lessons Learned}

The lessons learned report for the project can be obtained from Appendix F.

\subsection{Final Cost Report and Financial Closeout Status}

The total project cost (TPC) was estimated at \$9,483K. A breakdown of estimated final project costs by work breakdown structure (WBS) is provided in Table 2. Final project costs are through the fiscal month of May 2015 which is the last reporting period prior to submittal of the report. Additional minor costs may be incurred to for comment resolution and gain final approval of the CDE-4 package. Final cost closing statements will be prepared after CDE-4 approval as outlined in MCP-7001. 
Table 2: Total Project Cost by WBS

\begin{tabular}{|l|r|}
\hline \multicolumn{1}{|c|}{ WBS Description } & Cost (\$K) \\
\hline Project Initiation/Conceptual Design & $\$ 118$ \\
\hline Firewater System Design \& Construction & $\$ 4,725$ \\
\hline Firewater Lines Design \& Construction & $\$ 2,936$ \\
\hline Fuel Oil Tanks Design \& Demolition & $\$ 416$ \\
\hline Project Management & $\$ 555$ \\
\hline Project Turnover/Closeout & $\$ 79$ \\
\hline Total Project Cost & $\$ 8,829$ \\
\hline
\end{tabular}

\subsection{Closeout Approvals}

Upon approval of CDE-4 by the Project Management Executive (PME) the MFC Firewater Replacement Project will be closed. All project documents are closed and a final transfer from the Construction Subcontractor has been executed (see the executed form 432.04, Inspection and Project Transfer, in Appendix G). The facility has accepted the construction project in accordance with the Project Acceptance/Turnover Plan (Appendix H). The executed Transition to Operations Final Turnover Checklist is attached in Appendix I. Executed partial transfer checklists are not provided as attachments because the final transfer supersedes the partial transfers.

\section{APPENDIXES}

Appendix A, Final Project Schedule

Appendix B, Project Photos

Appendix C, Master Budget Log

Appendix D, Project Deficiency Punch List

Appendix E, Risk Register

Appendix F, Lessons Learned Report

Appendix G, Final Project Transfer

Appendix H, Project Acceptance/Turnover Plan

Appendix I, Executed Transition to Operations Final Turnover Checklist

Appendix J, Idaho Department of Environmental Quality Final Project Approval 


\section{Appendix A,}

\section{Final Project Schedule}

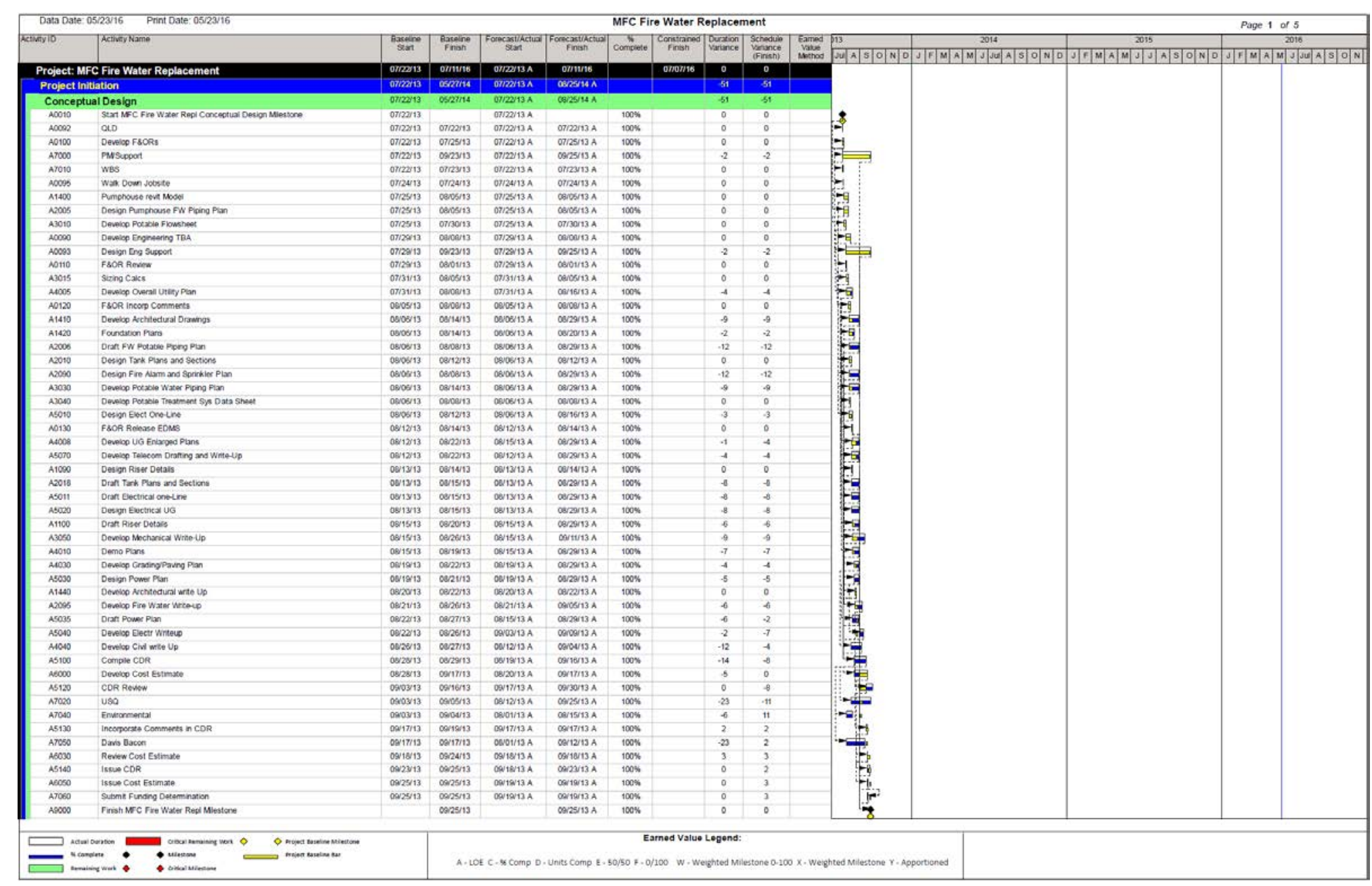




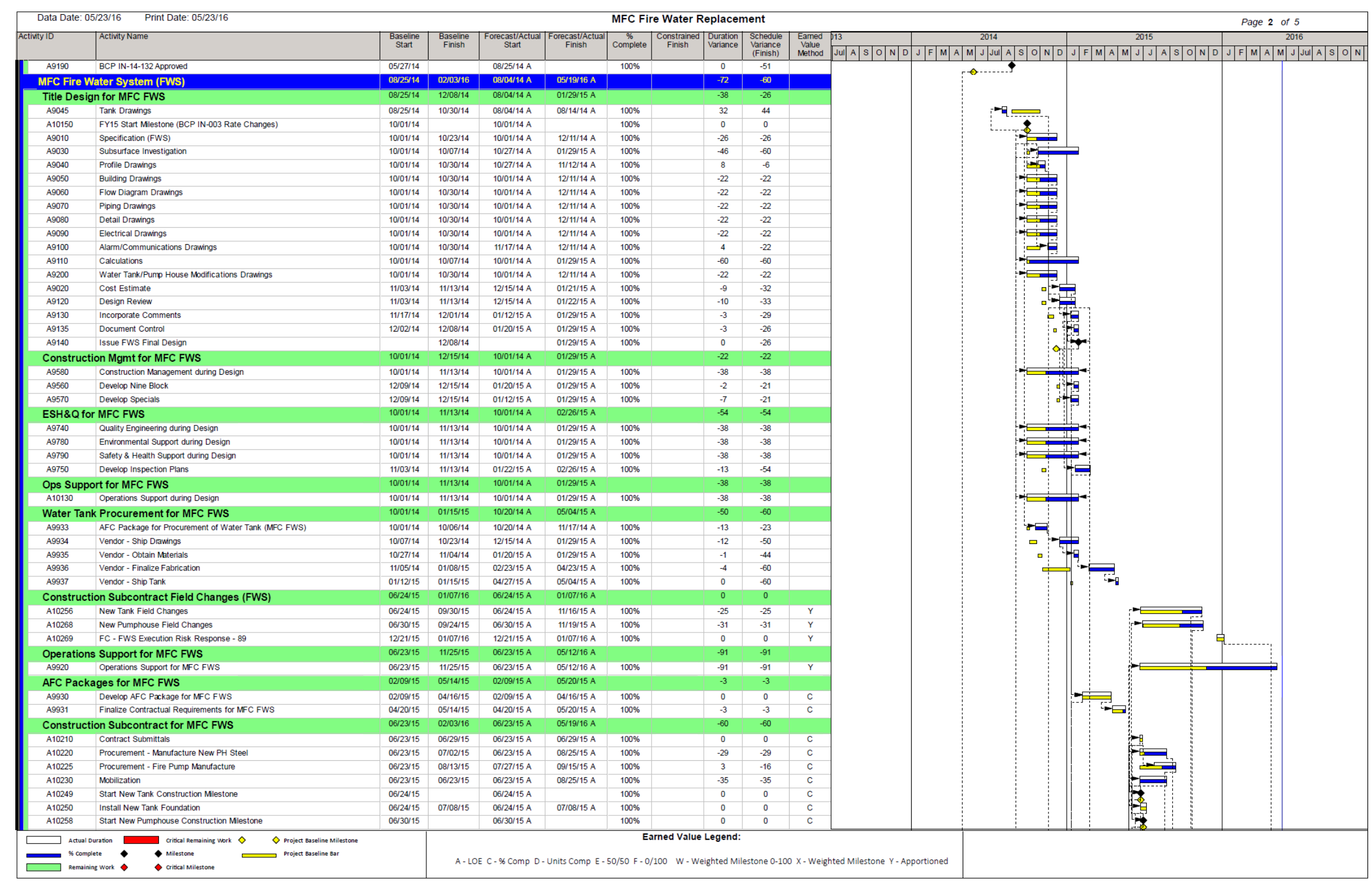




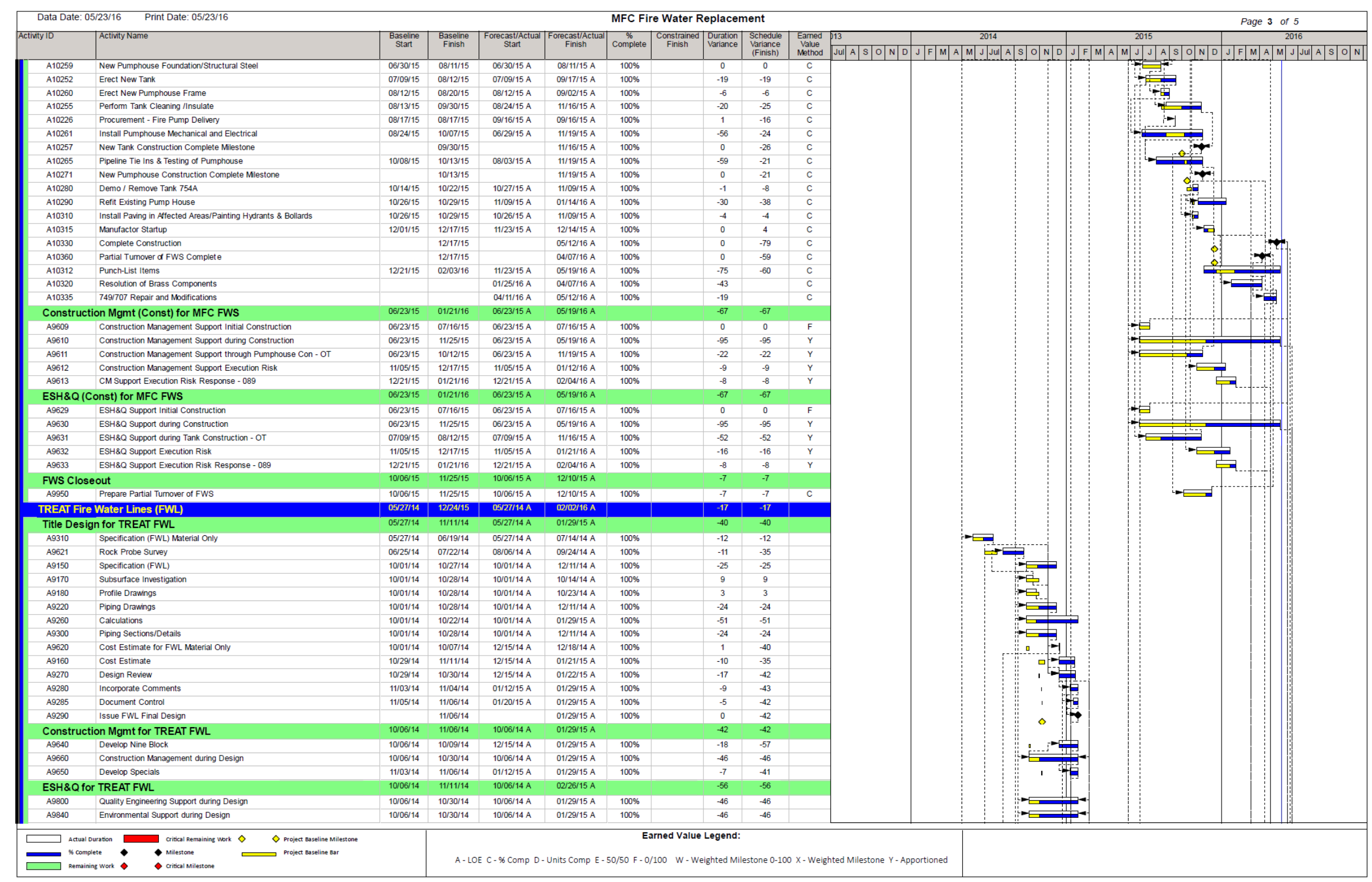




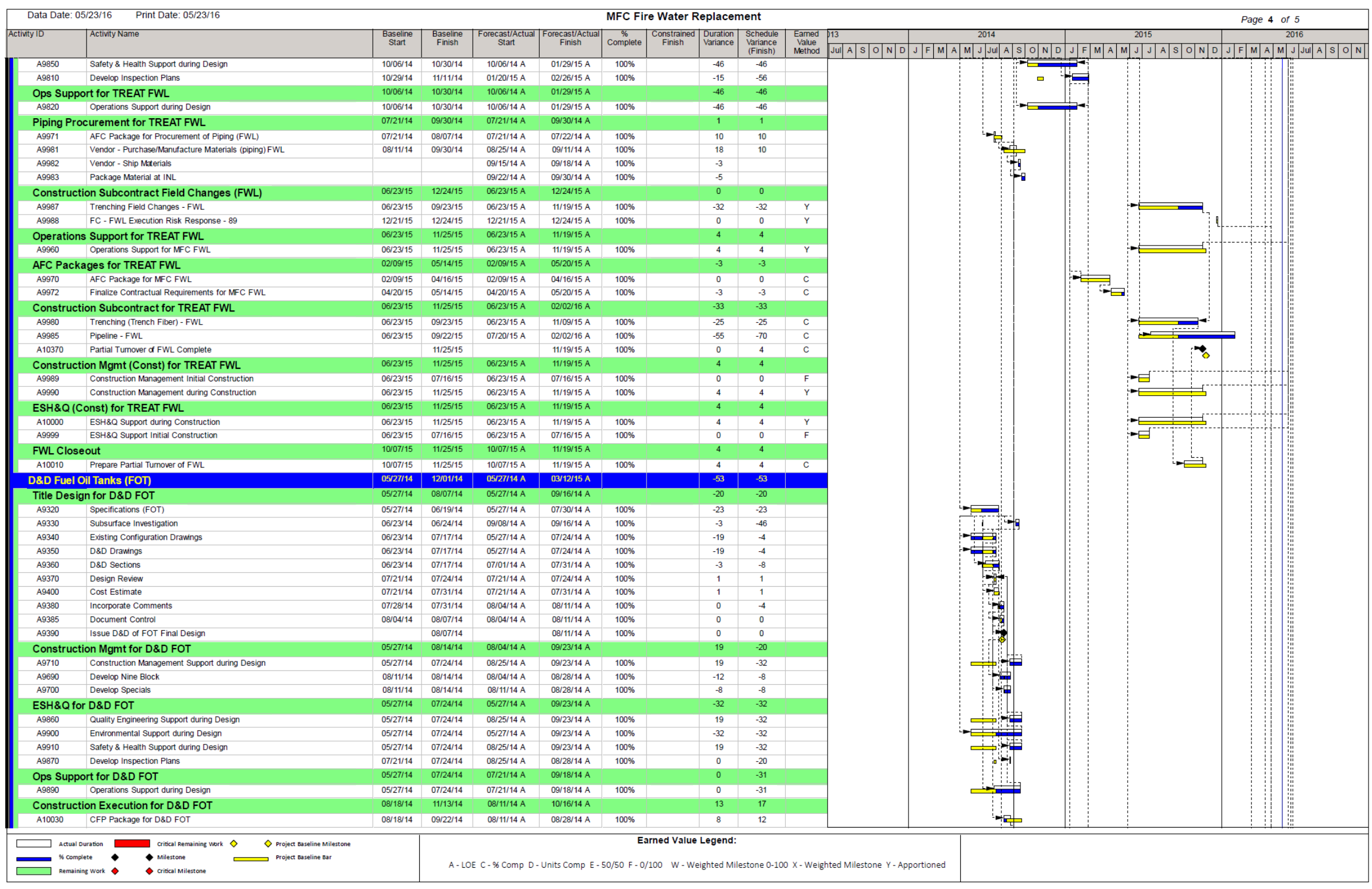




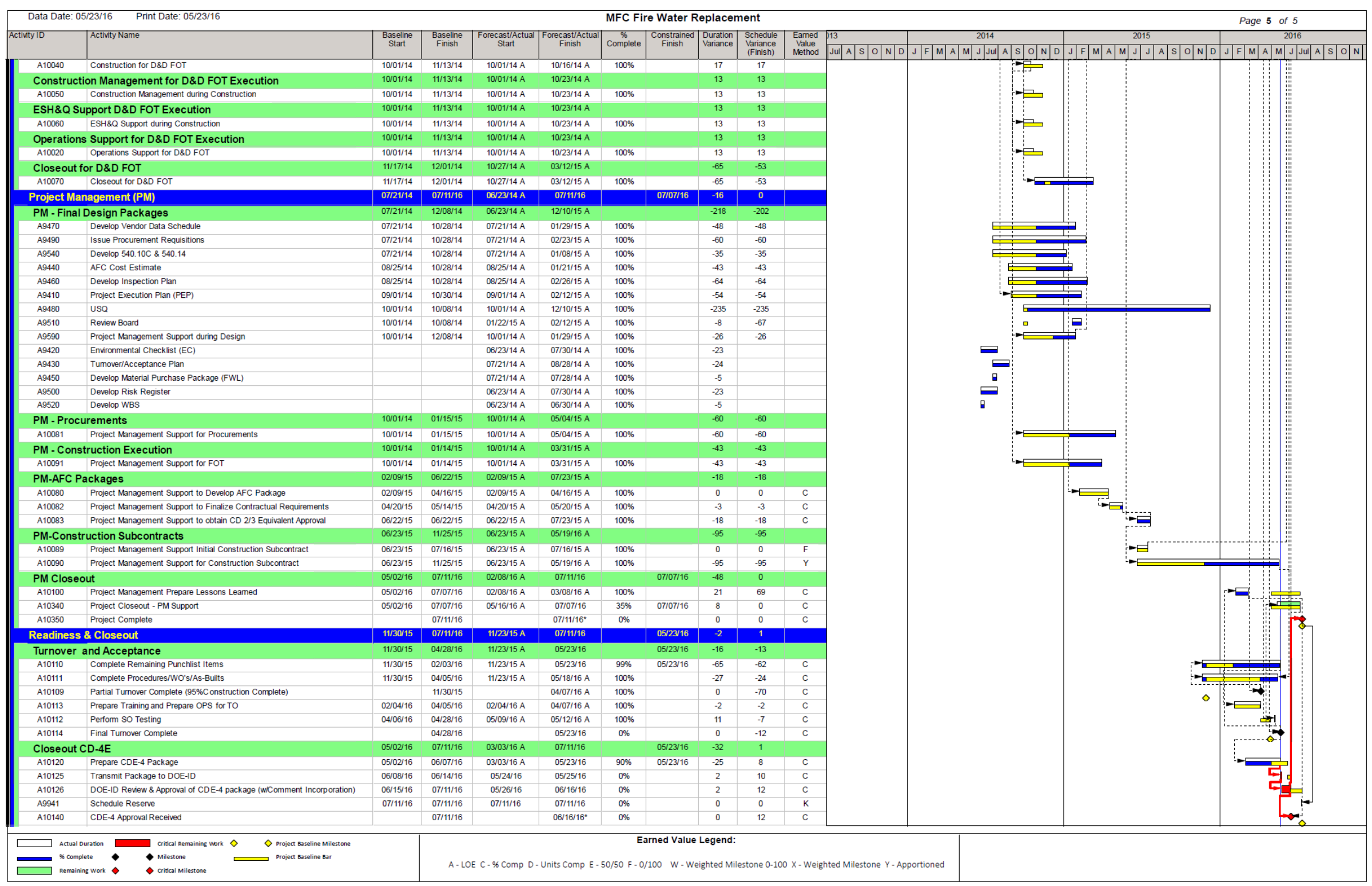




\section{Appendix B,}

\section{Project Photos}

\section{Buy-Down Activities - Late Summer 2014:}

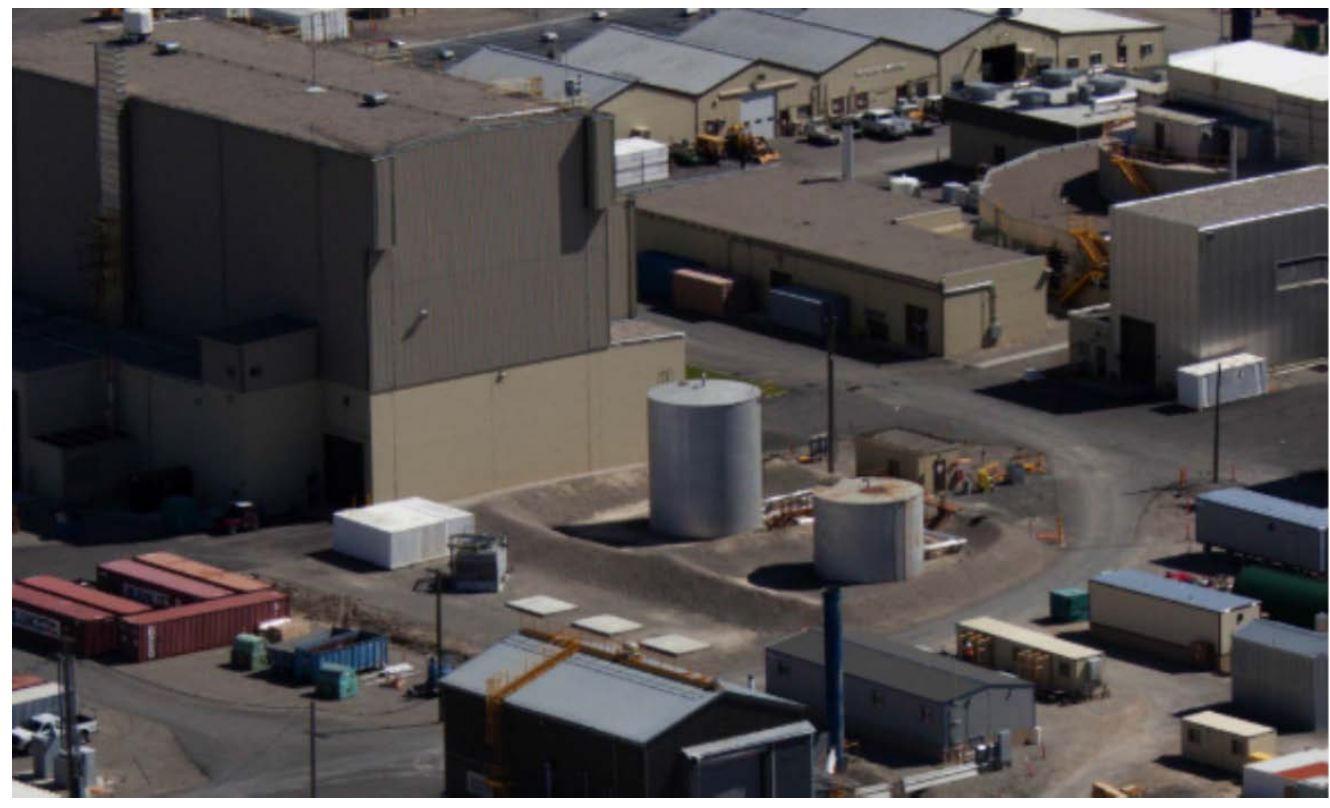

Fuel Oil Tanks Prior to Demolition (reference Environmental Checklist)

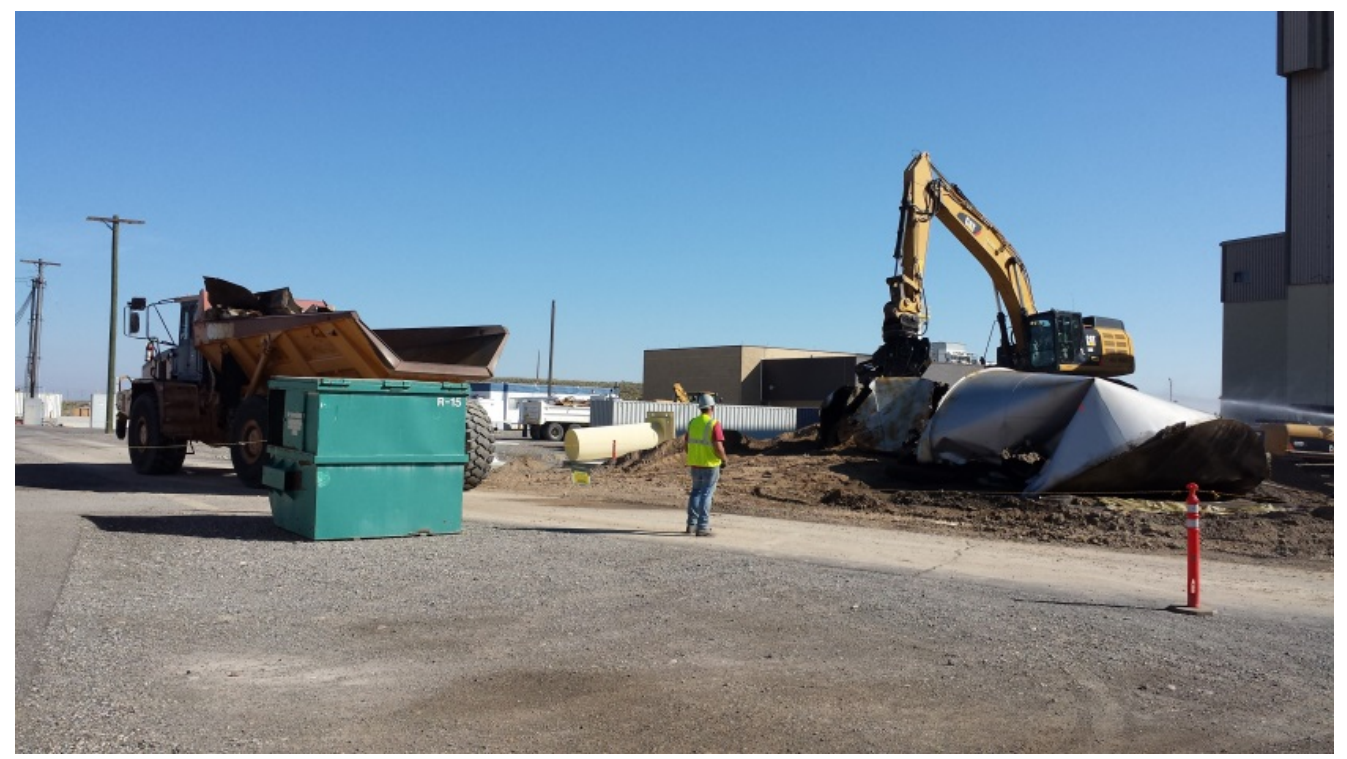

Fuel Oil Tanks during Demolition 


\section{Buy-Down Activities - Late Summer 2014 (continued):}
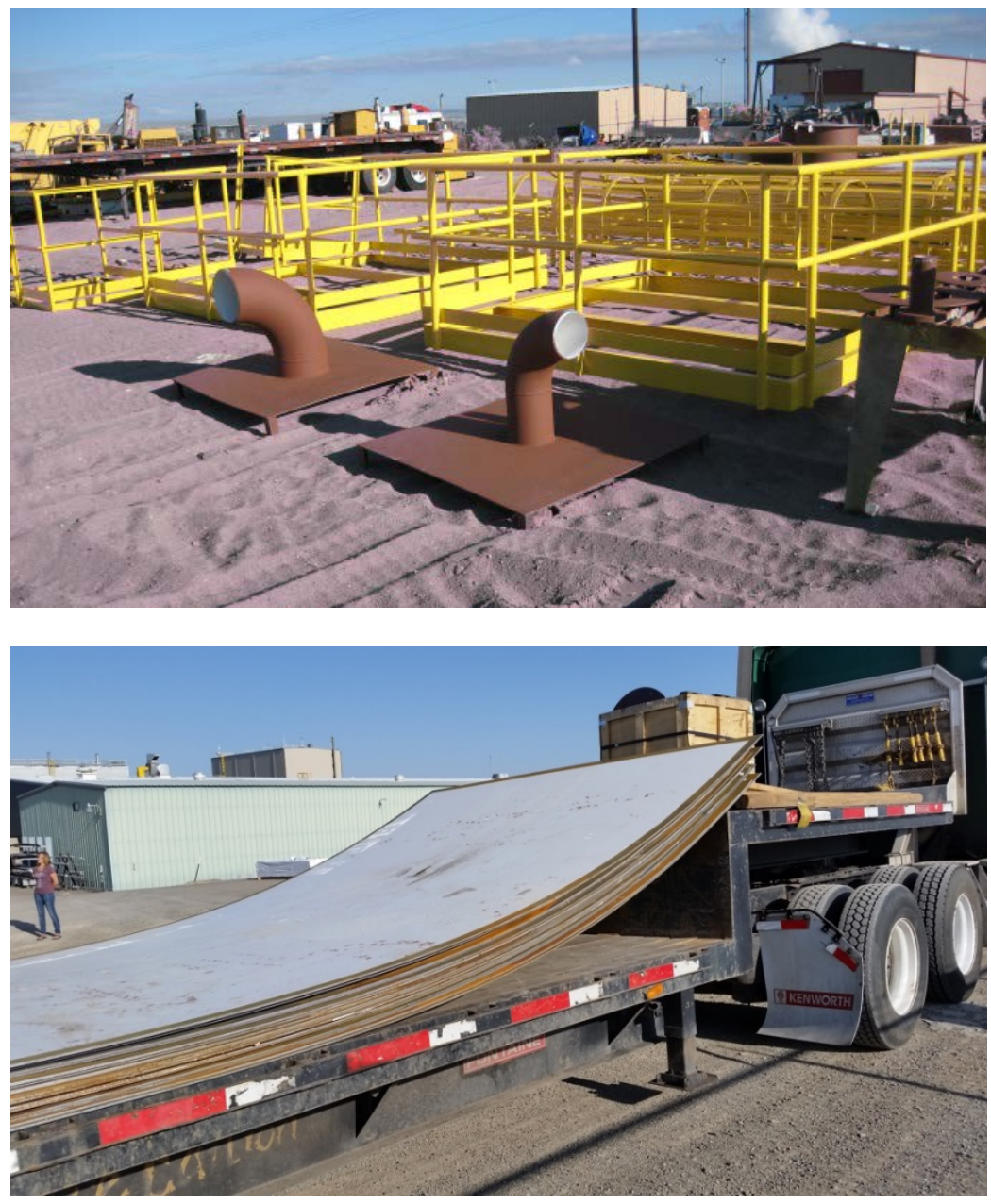

400,000 gallon tank - individual components for entire tank purchased and delivered to MFC

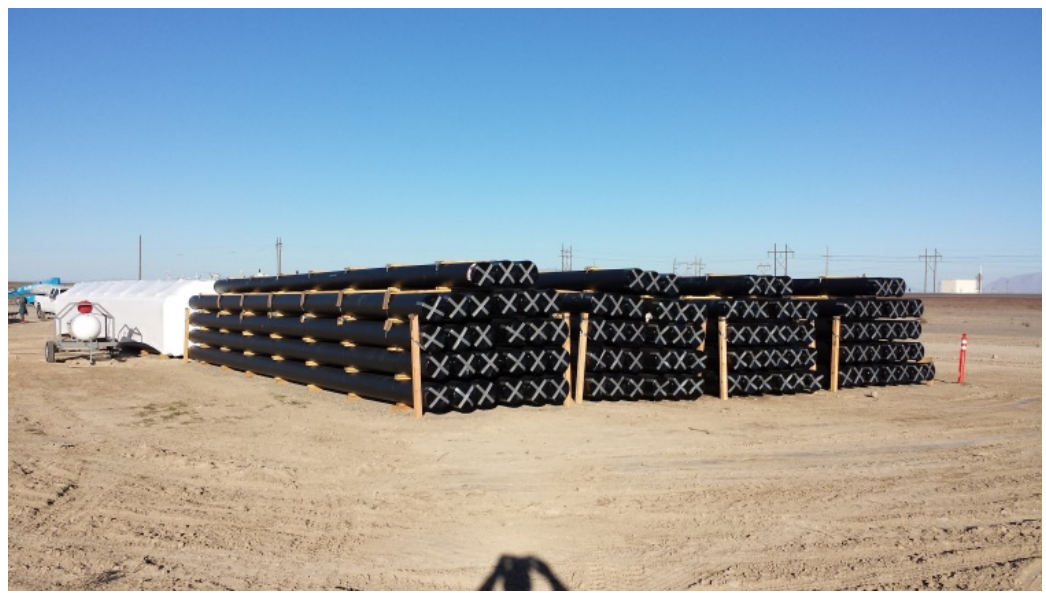

Over 1 mile of 14” HDPE pipe purchased and staged at MFC 
Start of Construction - Week of June 1, 2015:

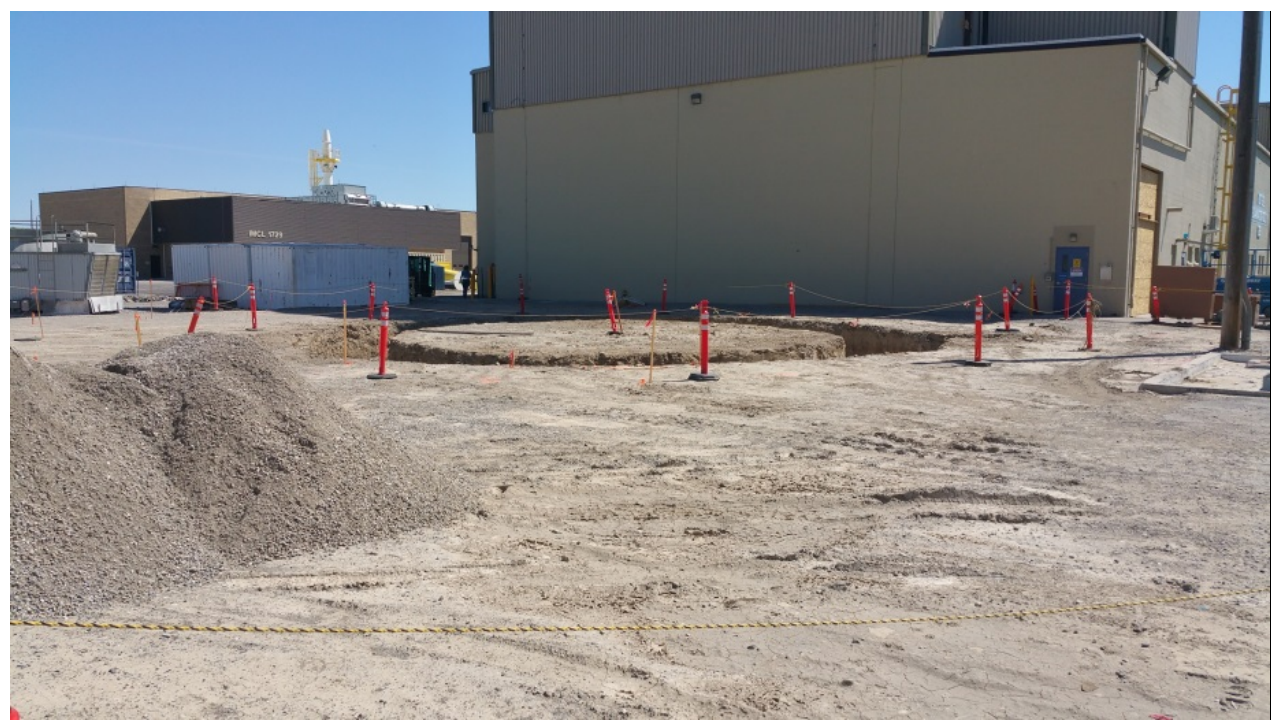

Excavation for footings of new 400,000 gallon tank

\section{Week of June 8, 2015:}

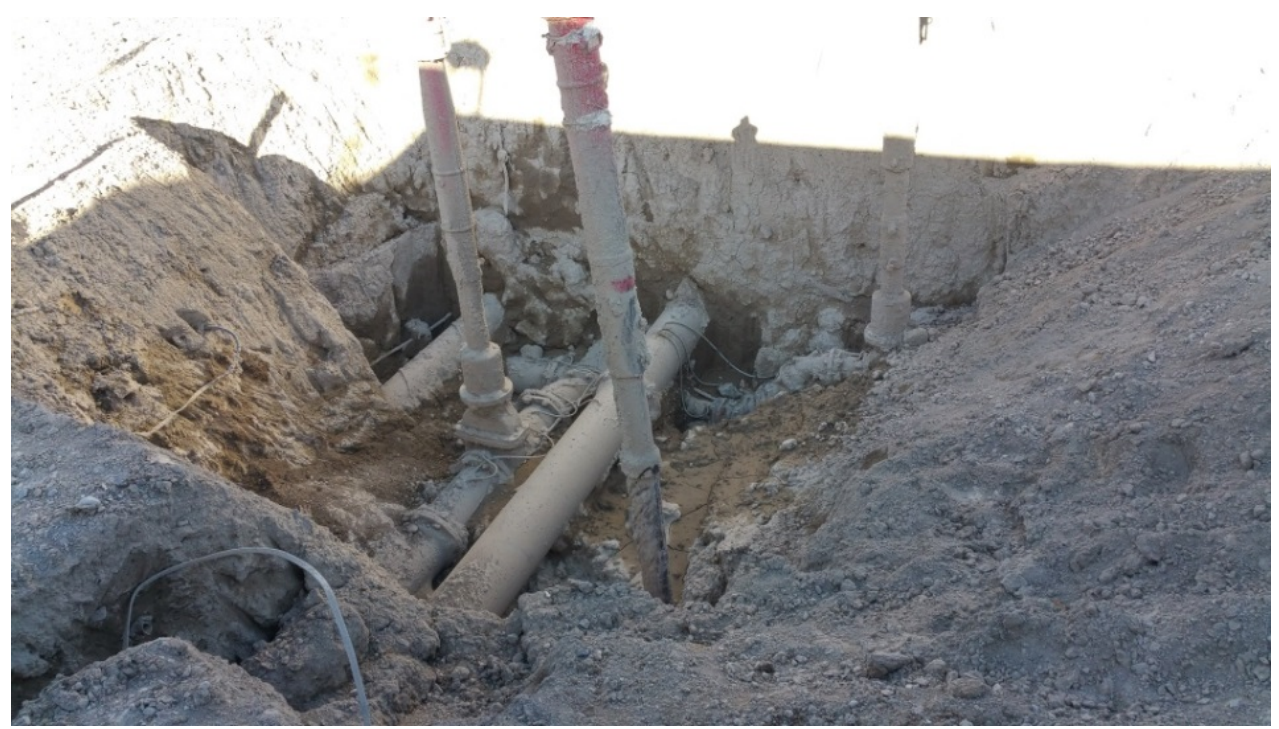

Excavation of existing piping systems for tie-in of temporary lines 
Week of June 15, 2015:

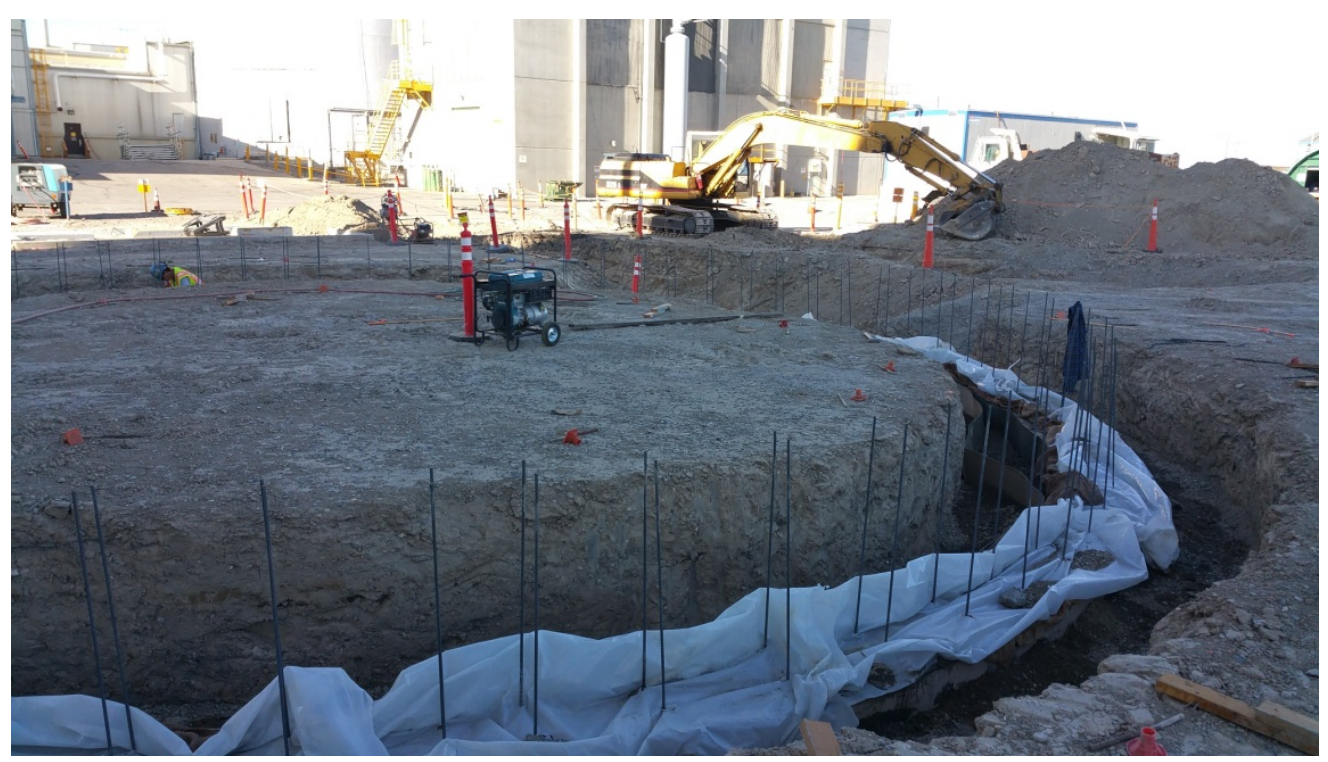

Structural steel for 400,000 gallon tank foundation

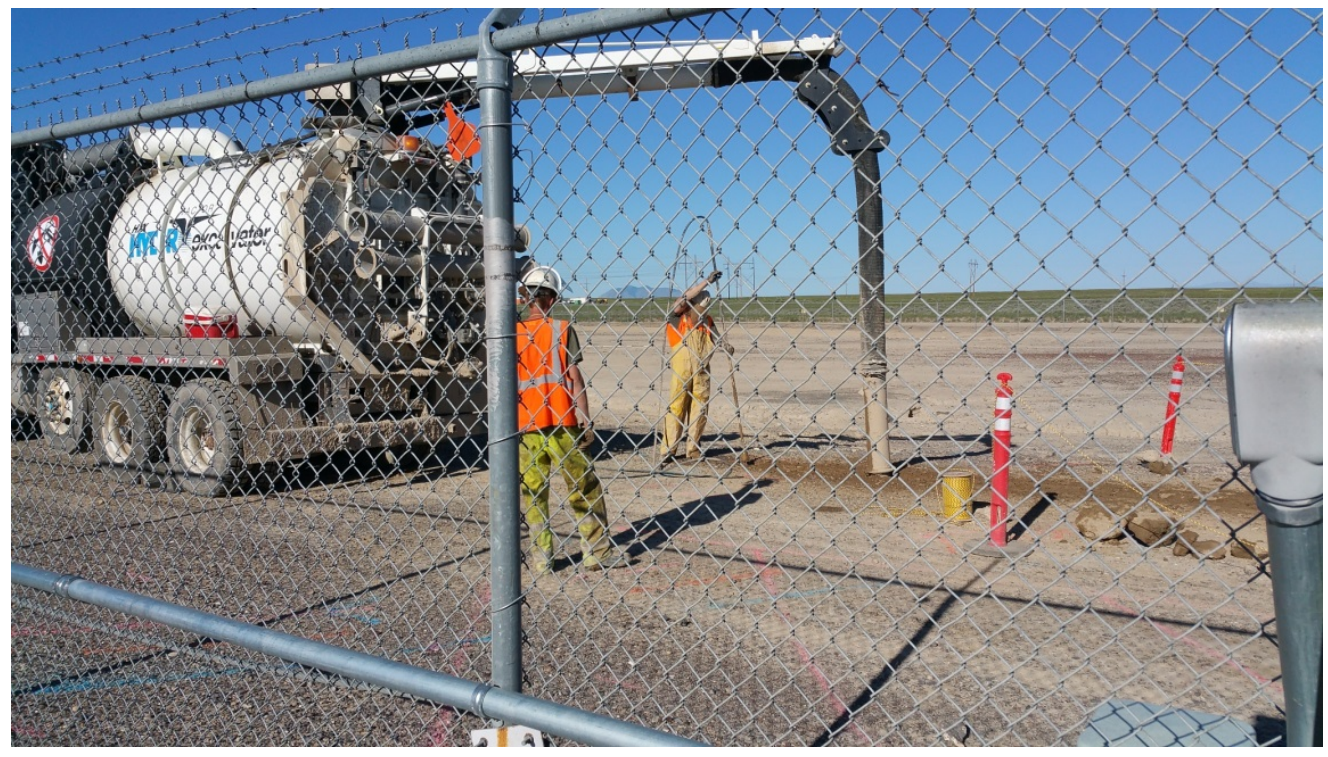

Vacuum excavation between MFC security fences 
Week of June 22, 2015:

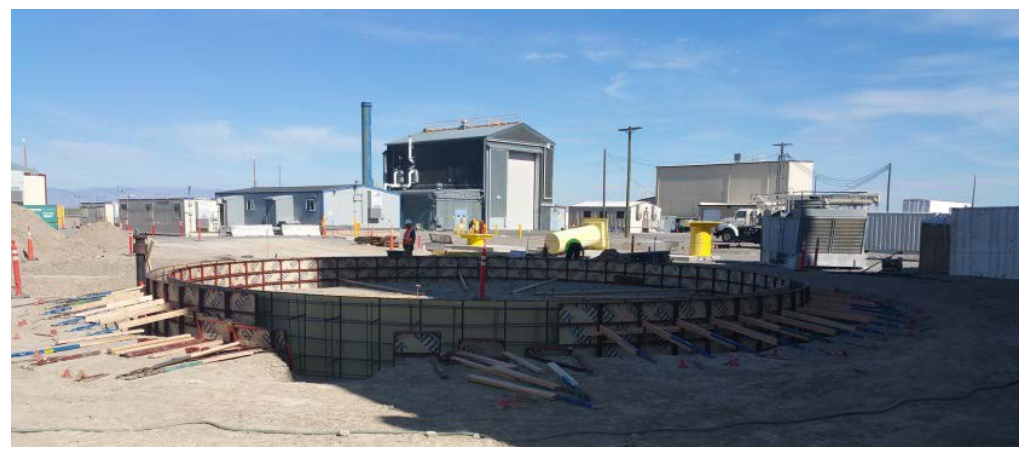

New 400,000 gallon tank foundation forms

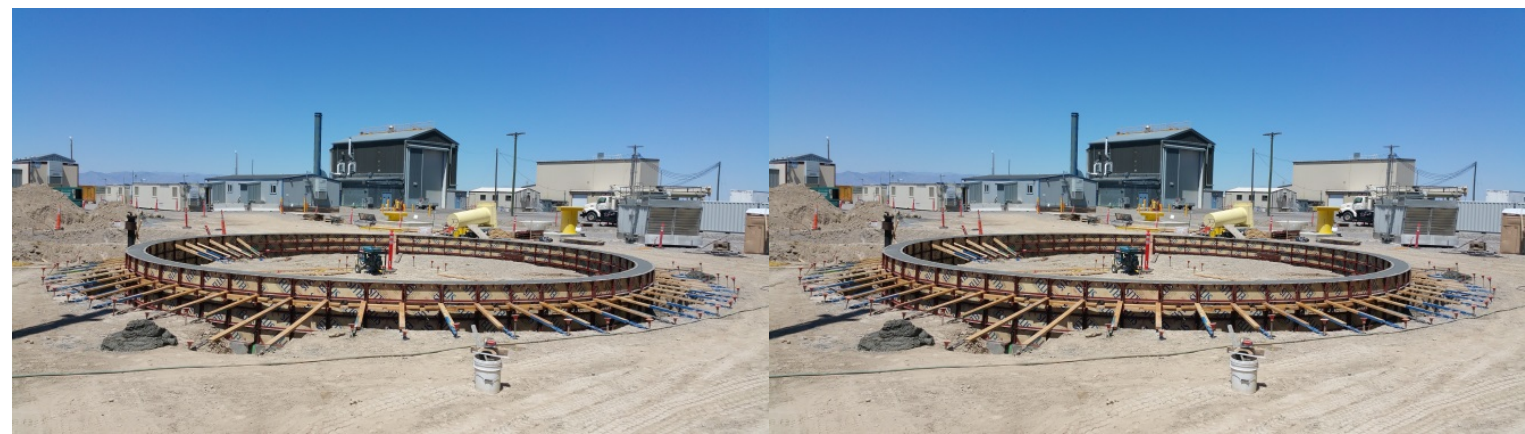

Concrete pour for 400,000 gallon tank foundation

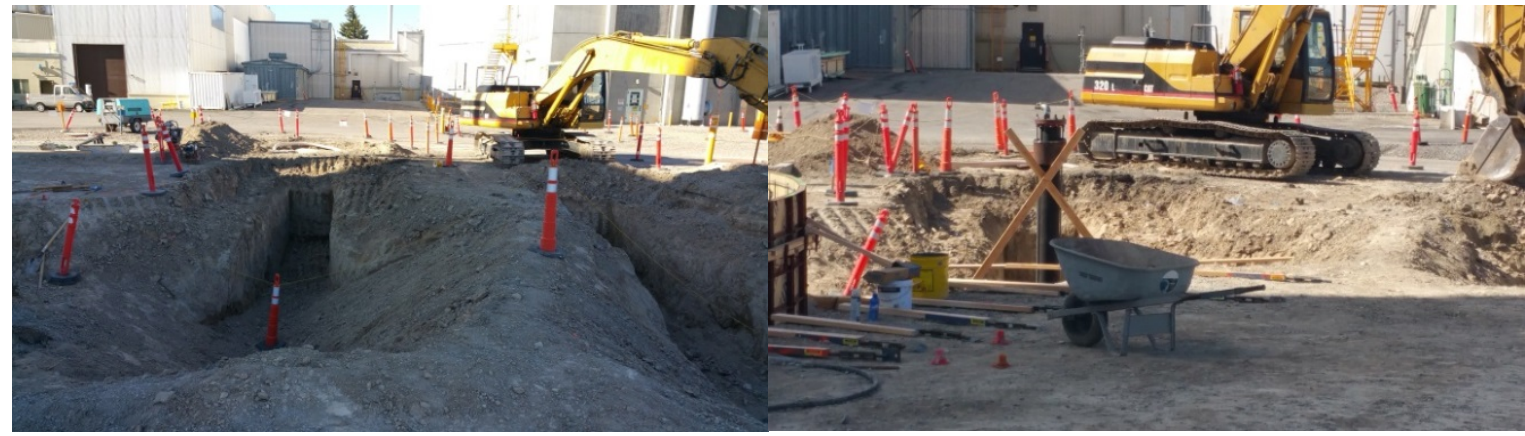

Excavation for pump house footings

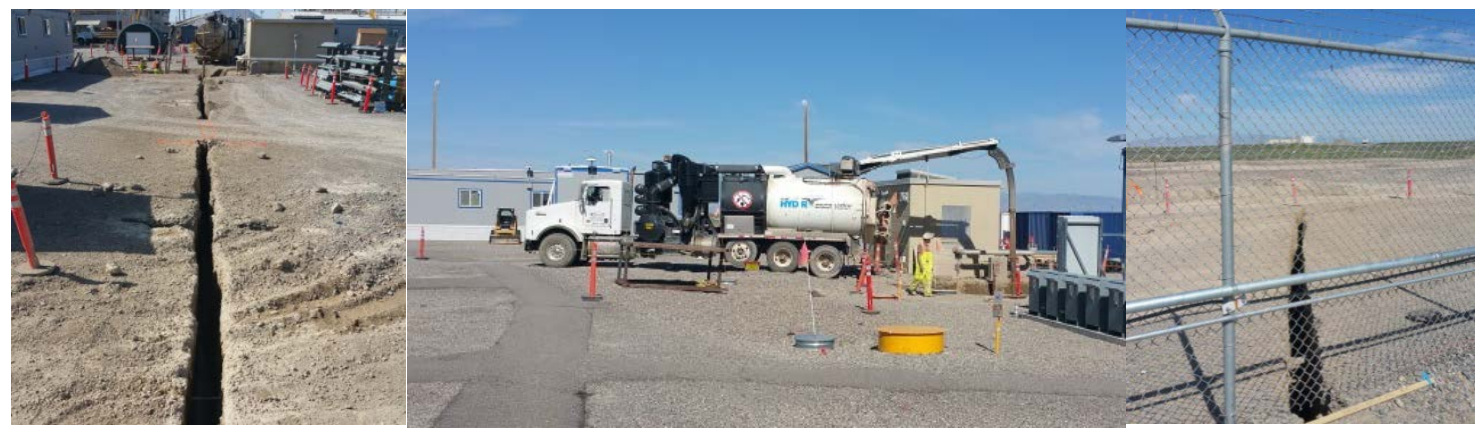

Vacuum excavation inside the MFC fences 
Week of June 29, 2015:

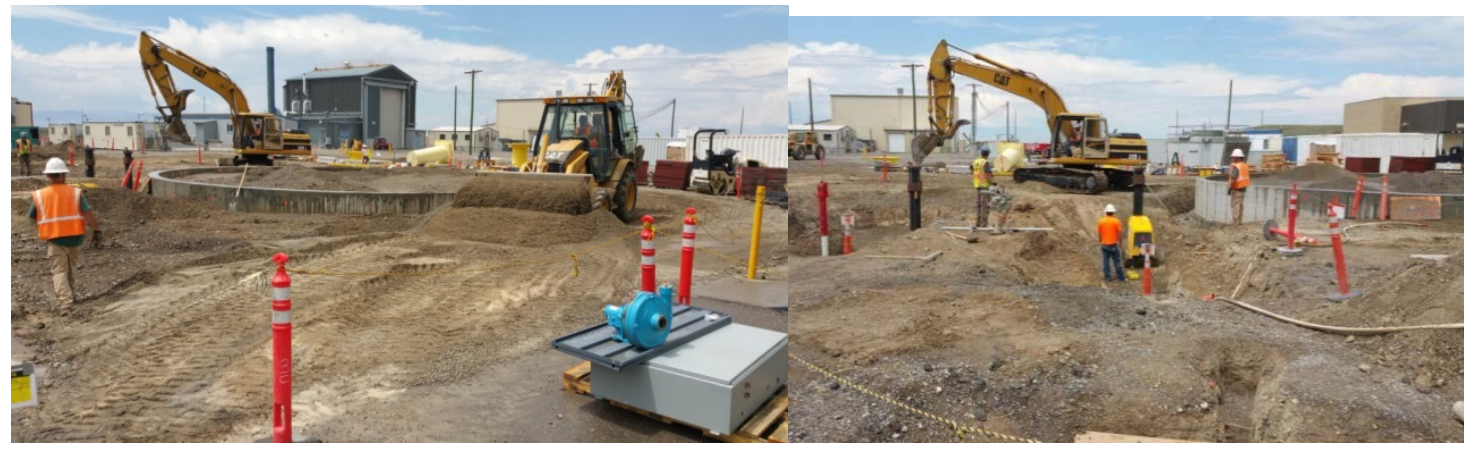

Tank Foundation backfill and Pump house excavation

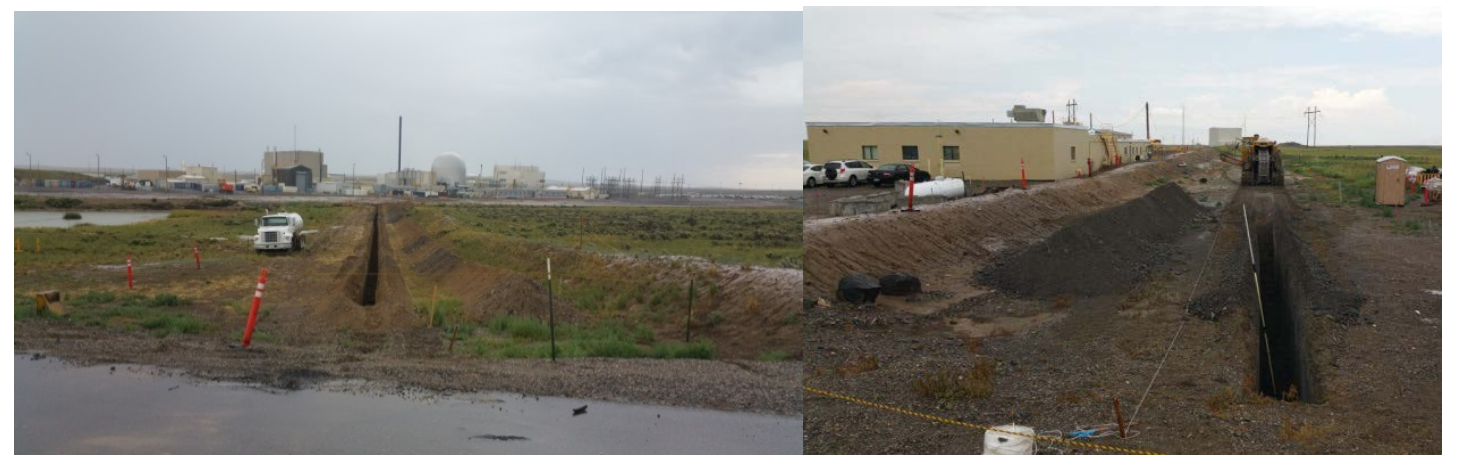

East view of north loop trench; west view of trench behind TREAT support buildings

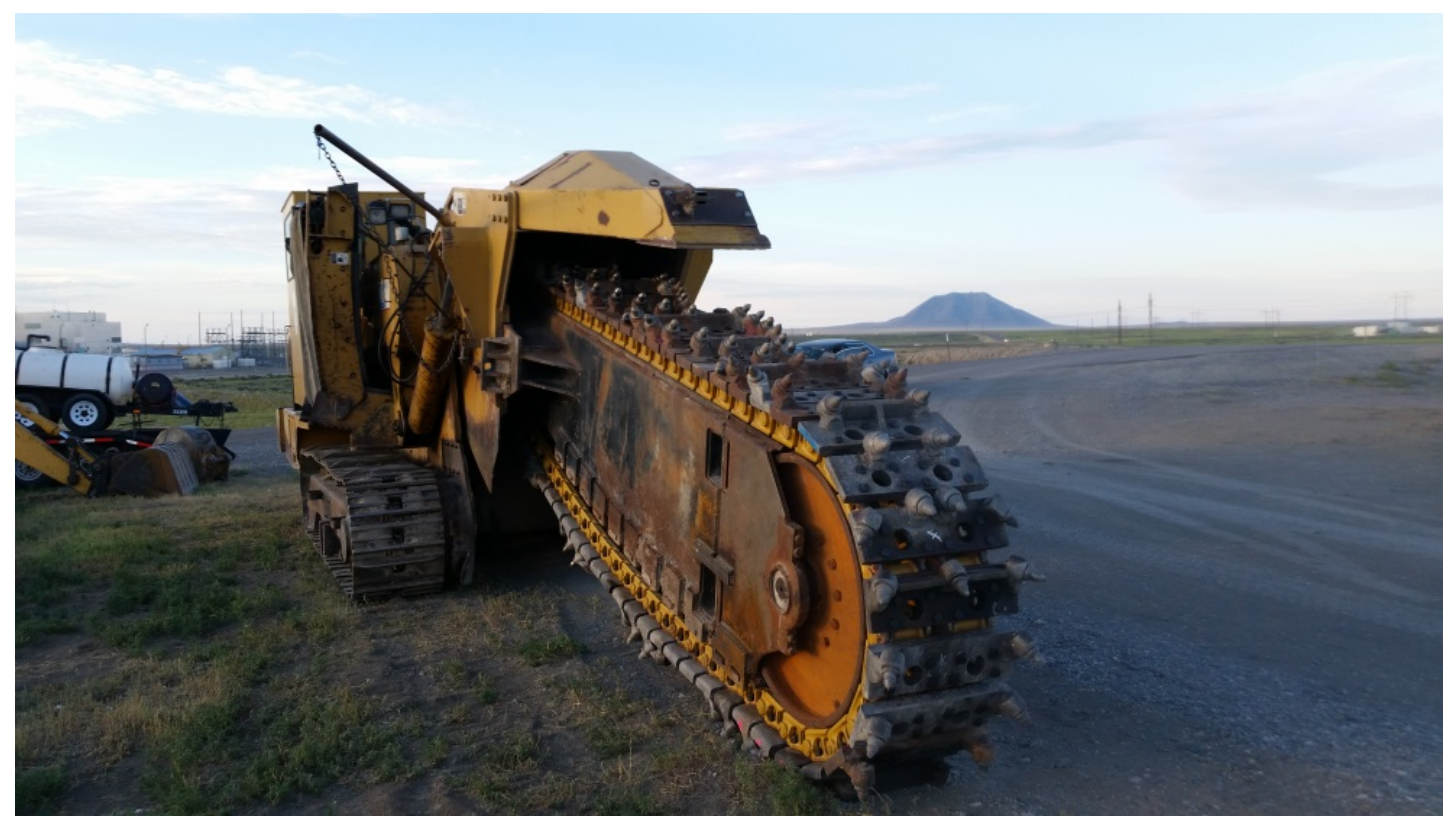

Rockcutter for 14” HDPE loop to TREAT 


\section{Week of July 6, 2015:}

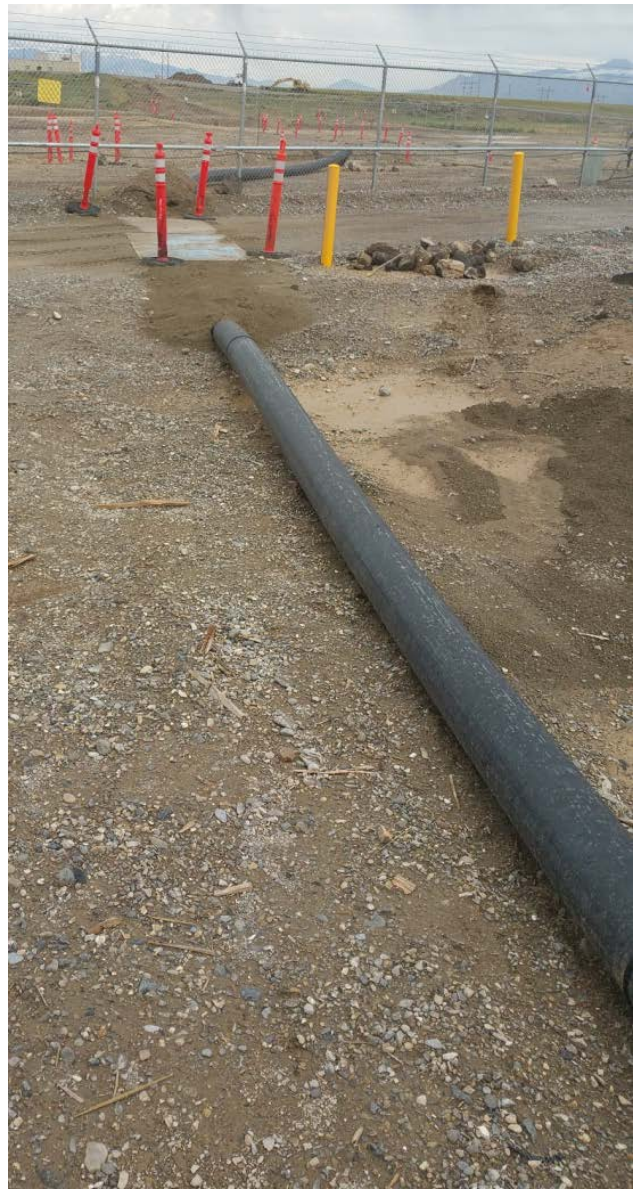

Temporary piping inside MFC Fence

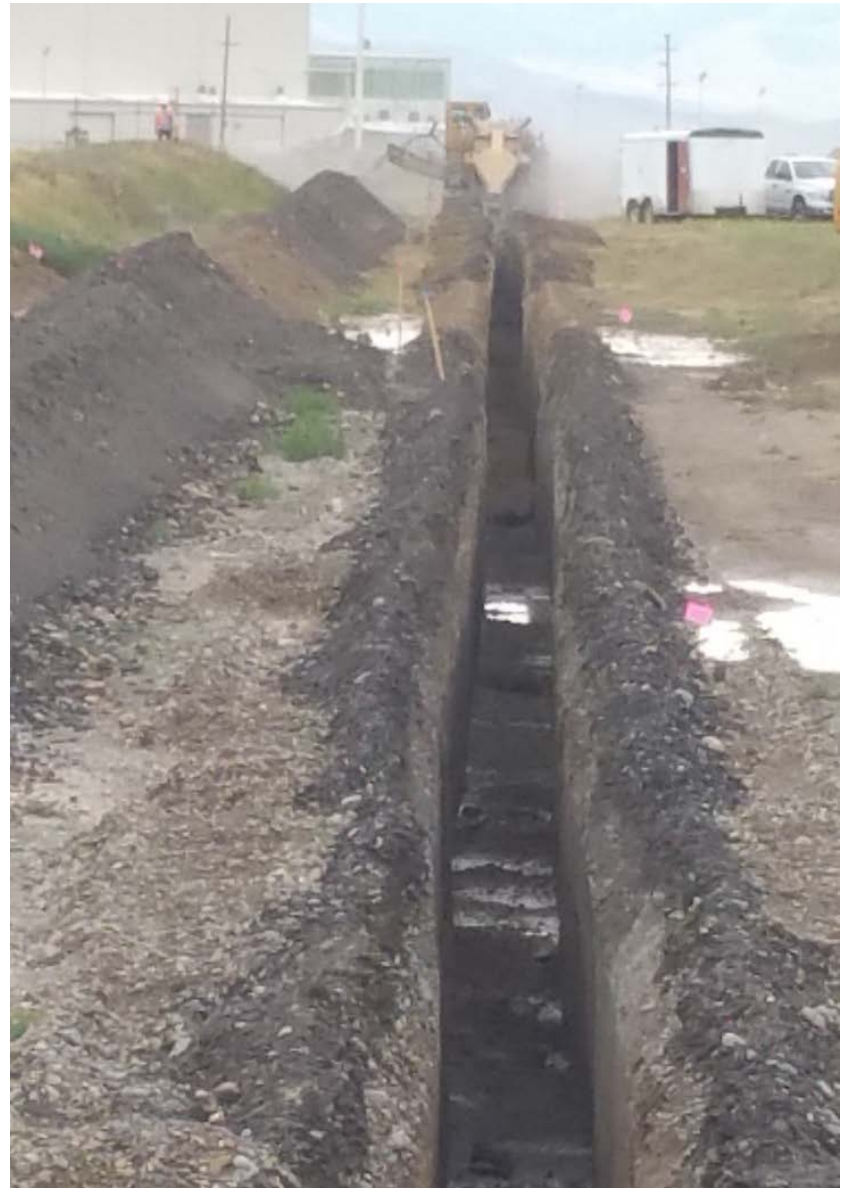

Trencher approaching TREAT - black basalt tailings

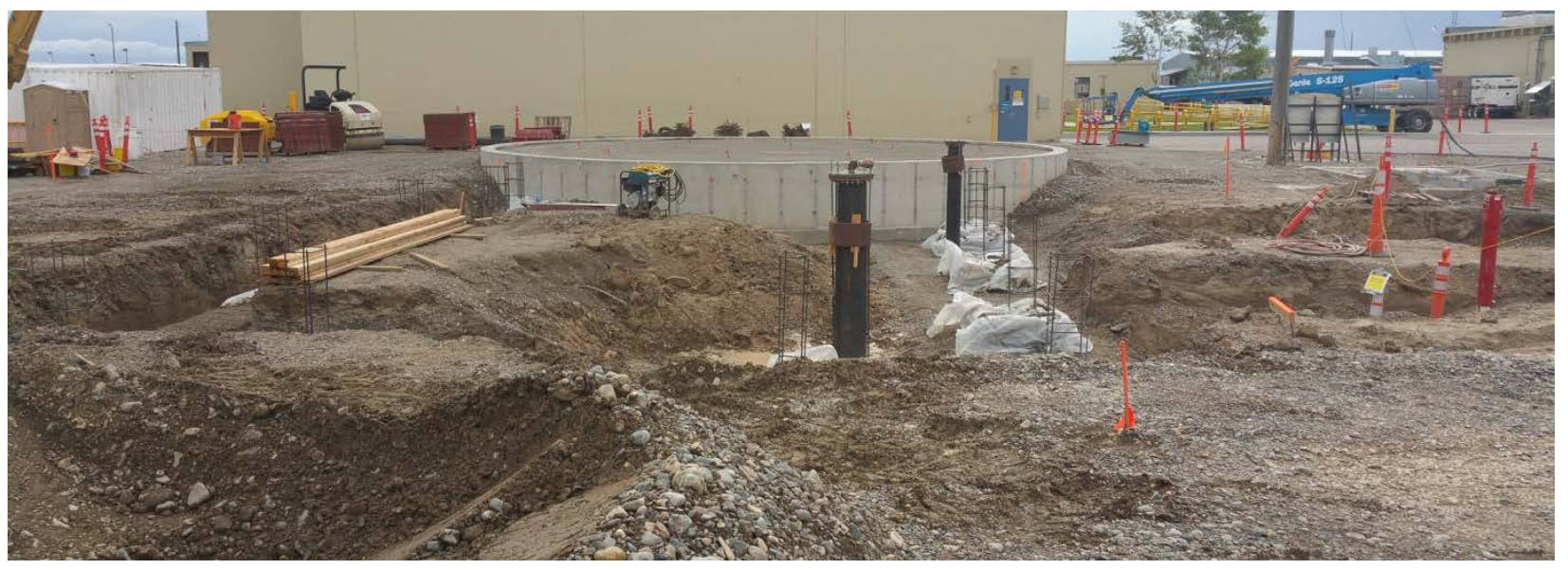

New tank foundation, pump house footings and piping stubs 
Week of July 13, 2015:

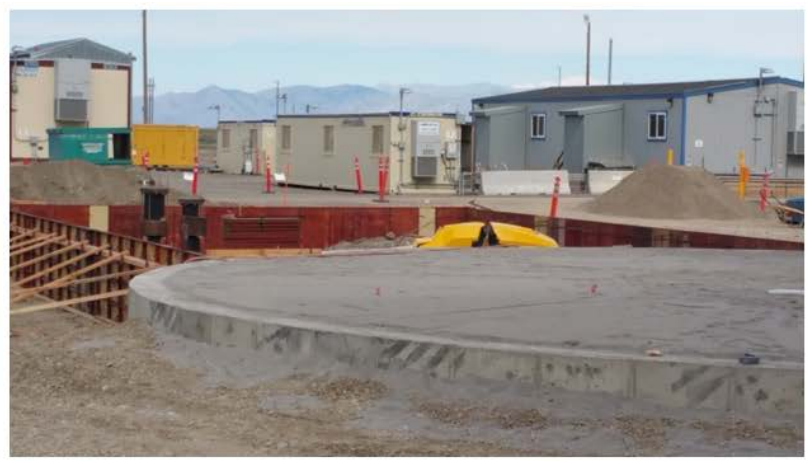

Lime Sand Base for Tank

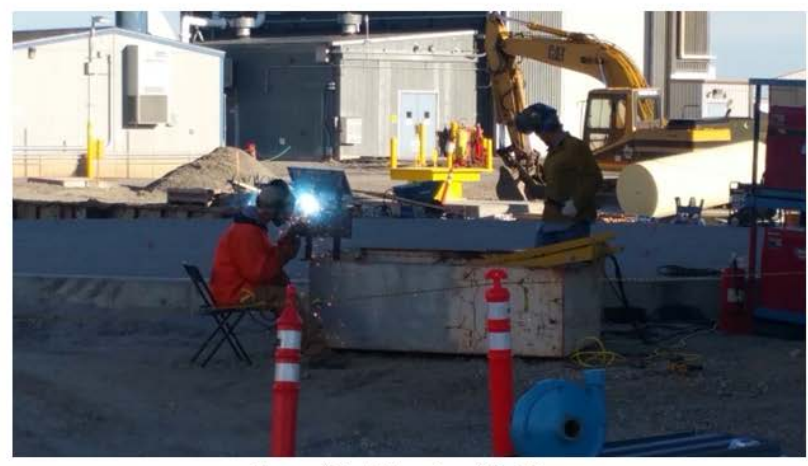

Start of Tank Erection/Welding

Week of July 20, 2015:

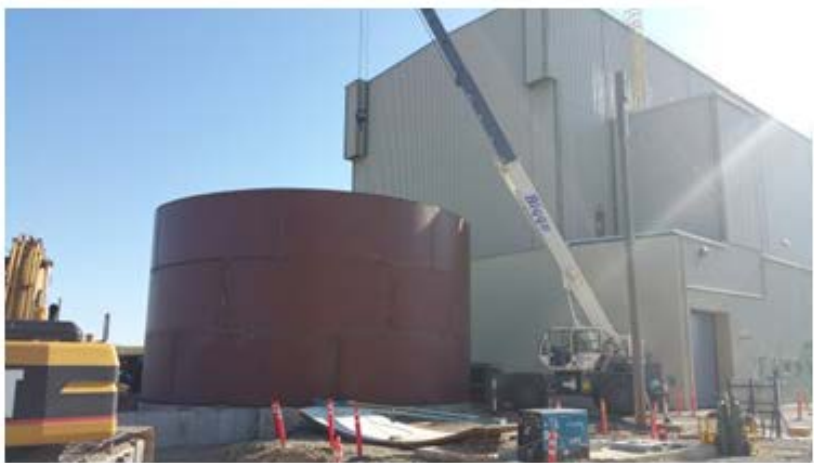

Tank Construction

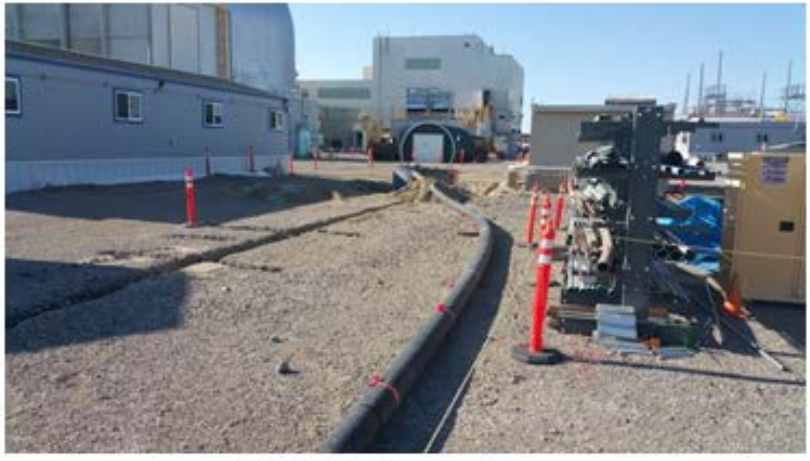

Tie in of $8 *$ Temporary Line

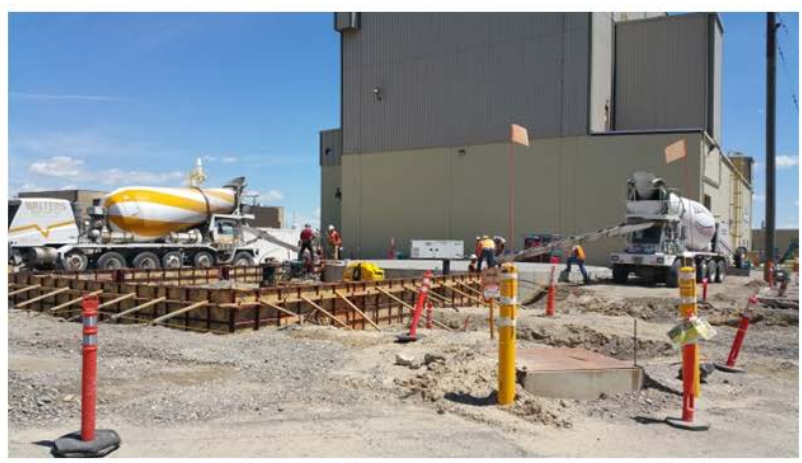

Pumphouse|Grade Beams Poured

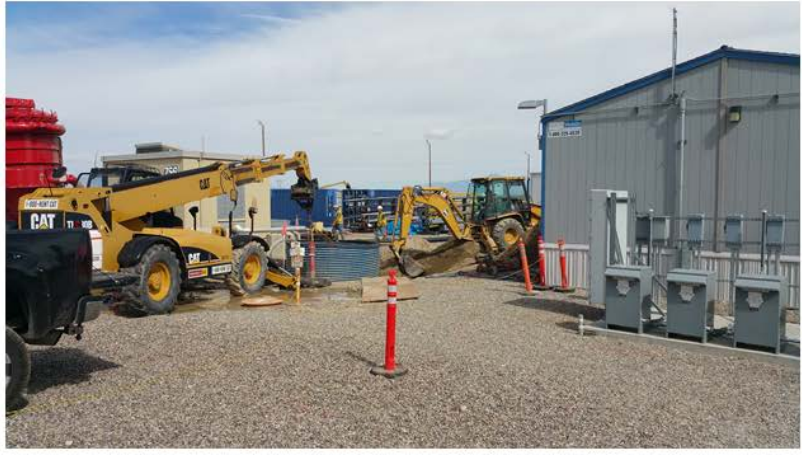

Tie-ins of Temporary Lines to TREAT

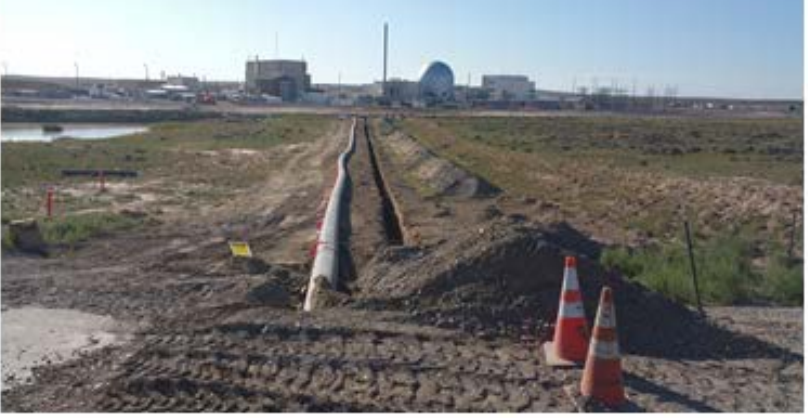

Assembly of 14" HDPE North Line

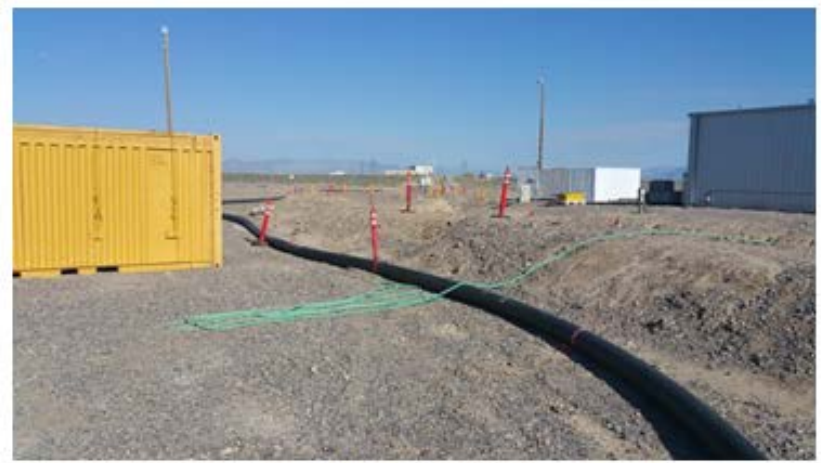

8" Temporary Line 
Week of July 27, 2015:

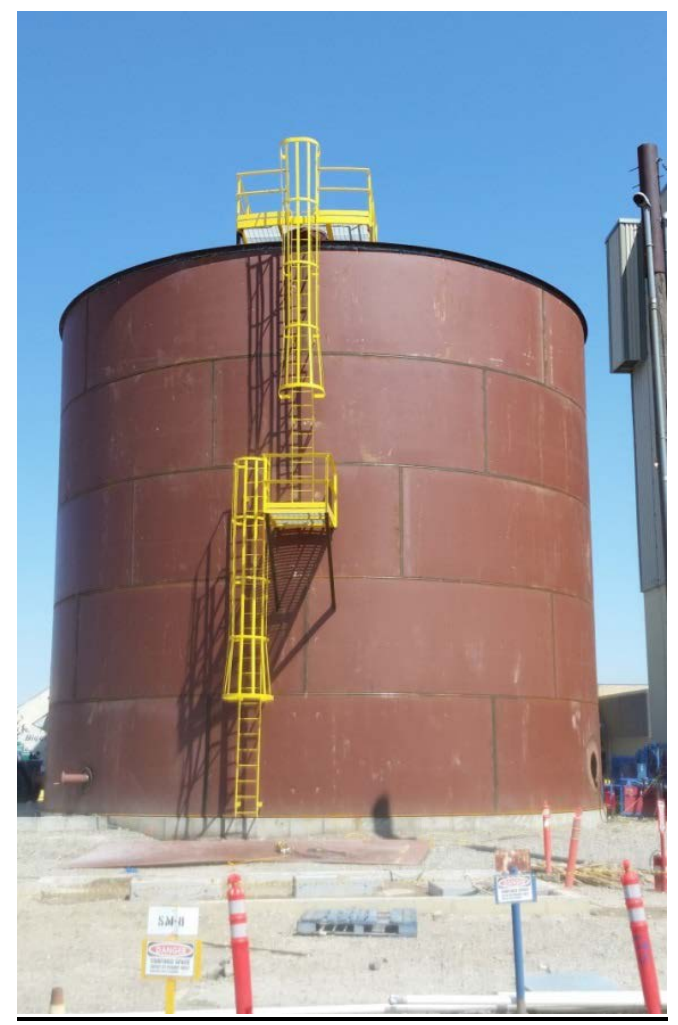

New 400,000 Gallon Tank looking north with ladders and platforms attached

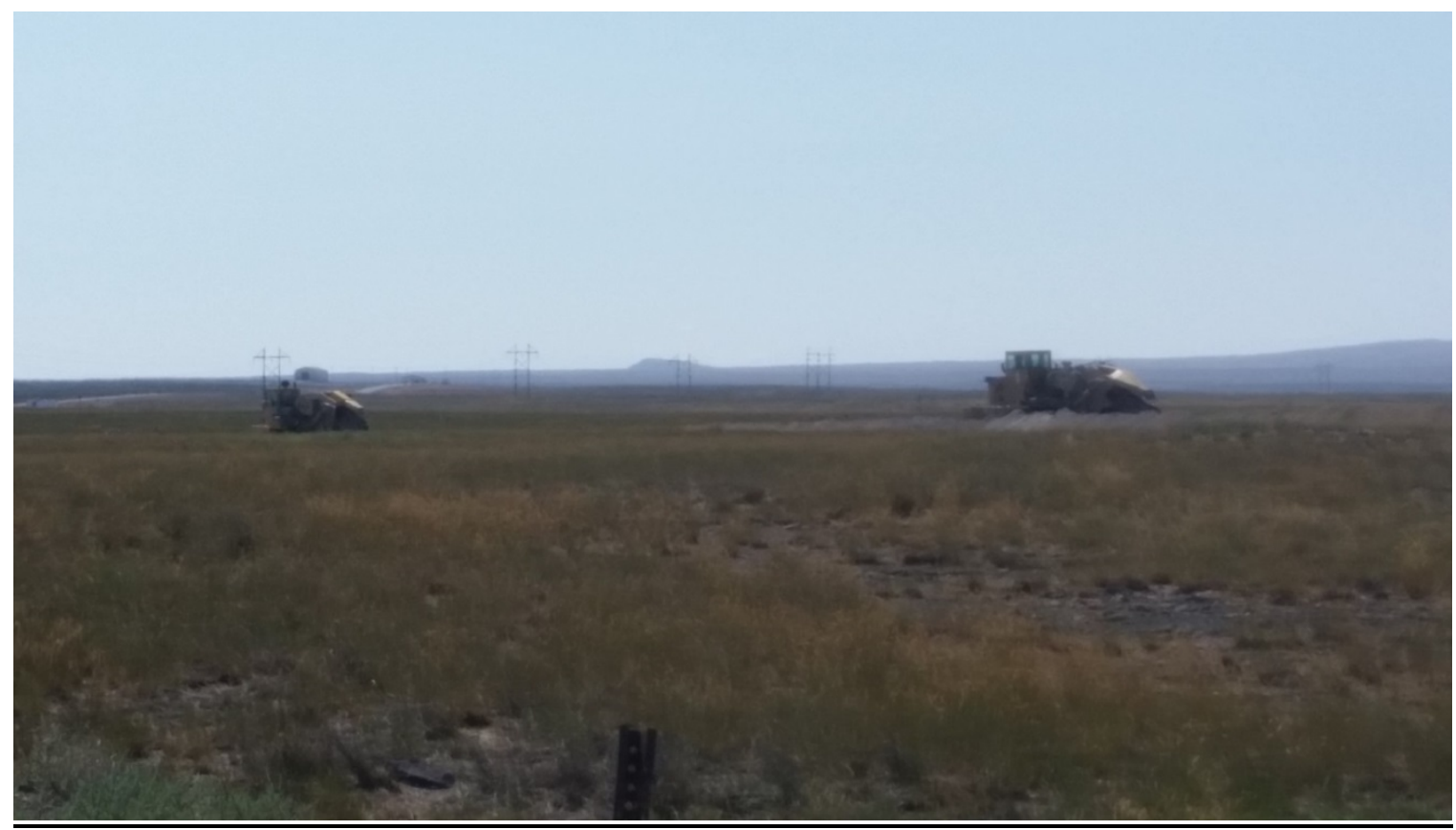

Two rock saws cutting the fire water trench through basalt on the south loop 
Week of August 3, 2015:

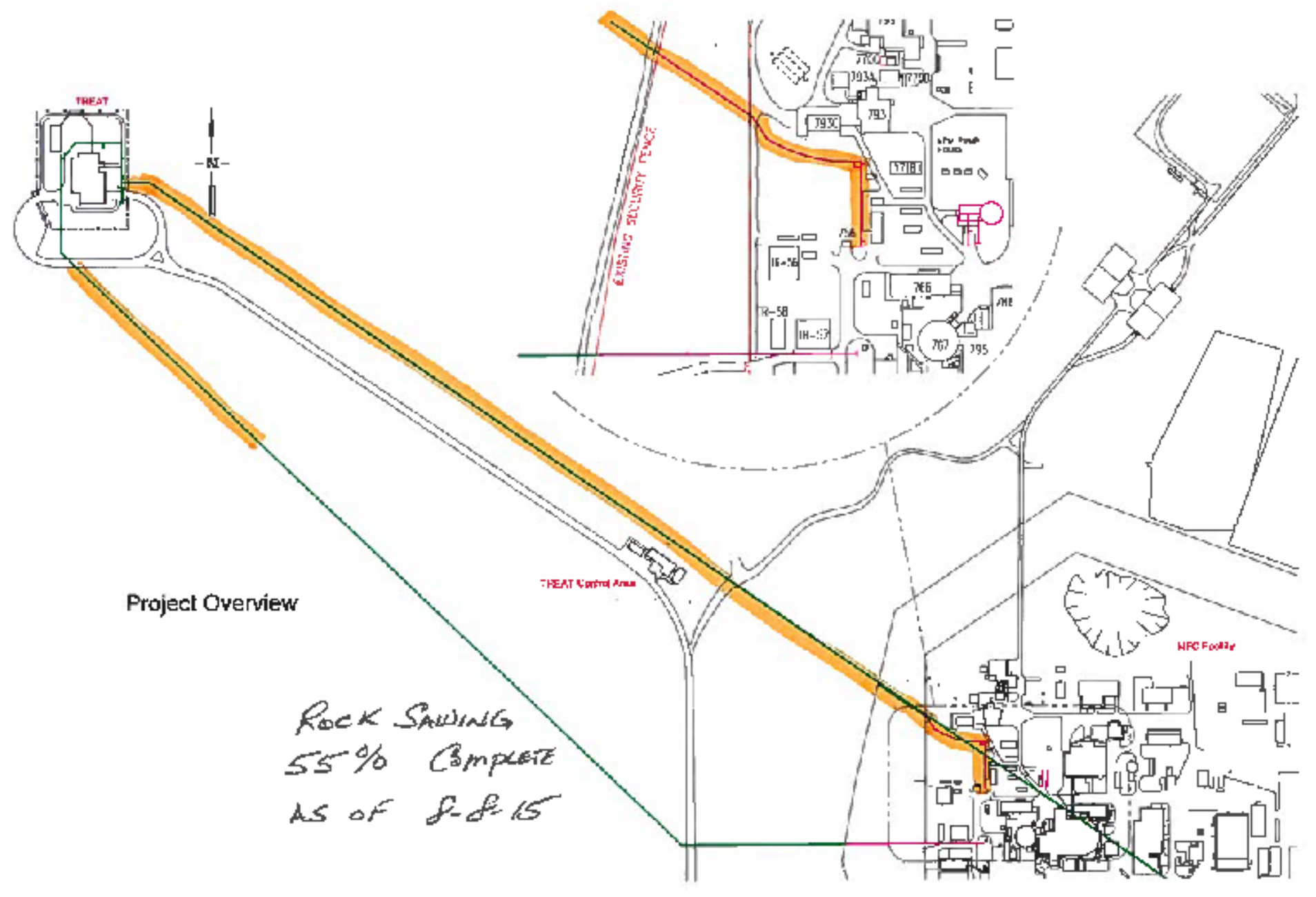

Yellow highlighting indicates trenching completed to-date. 
Week of August 10, 2015:

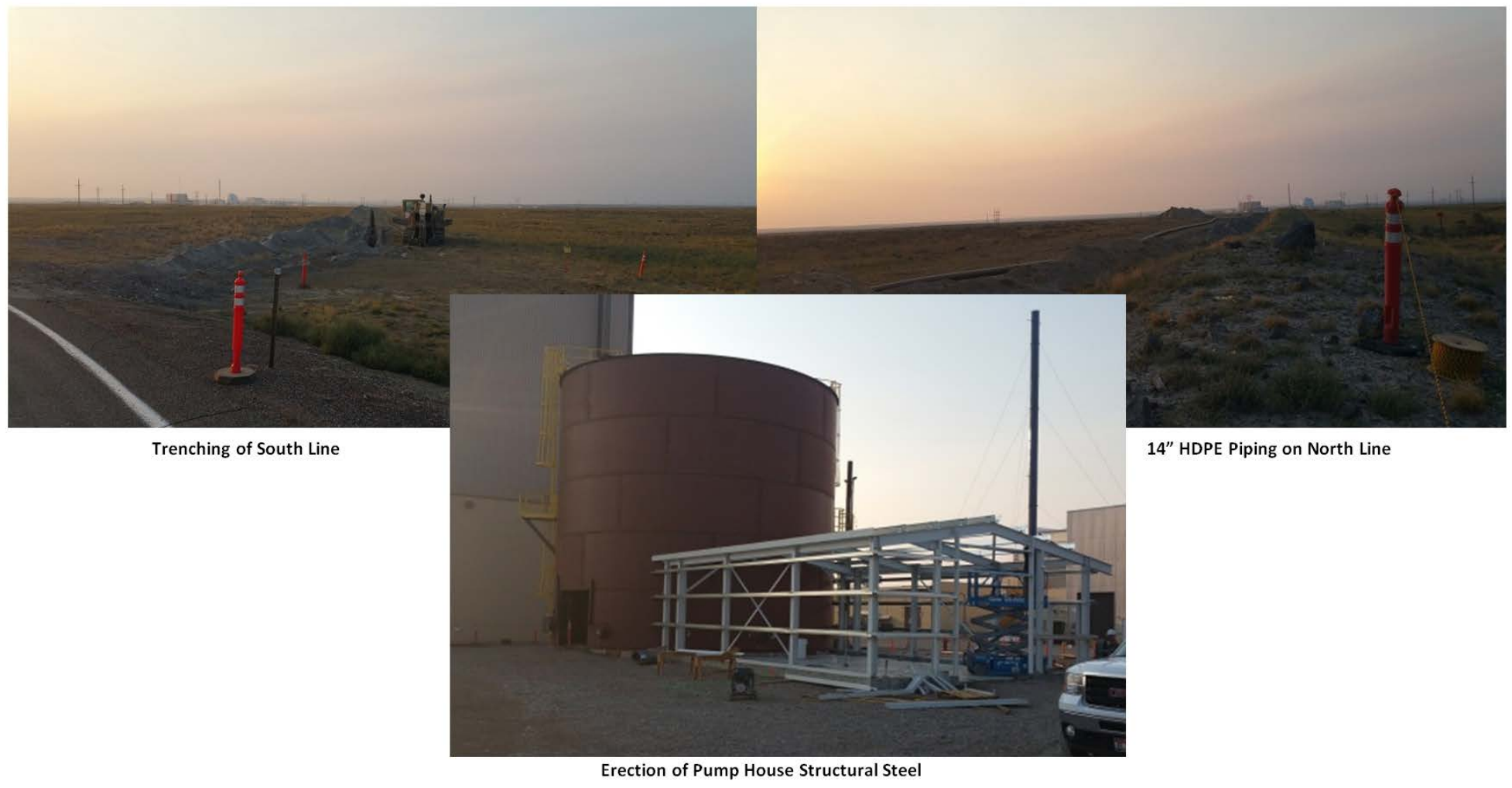

Week of August 17, 2015:

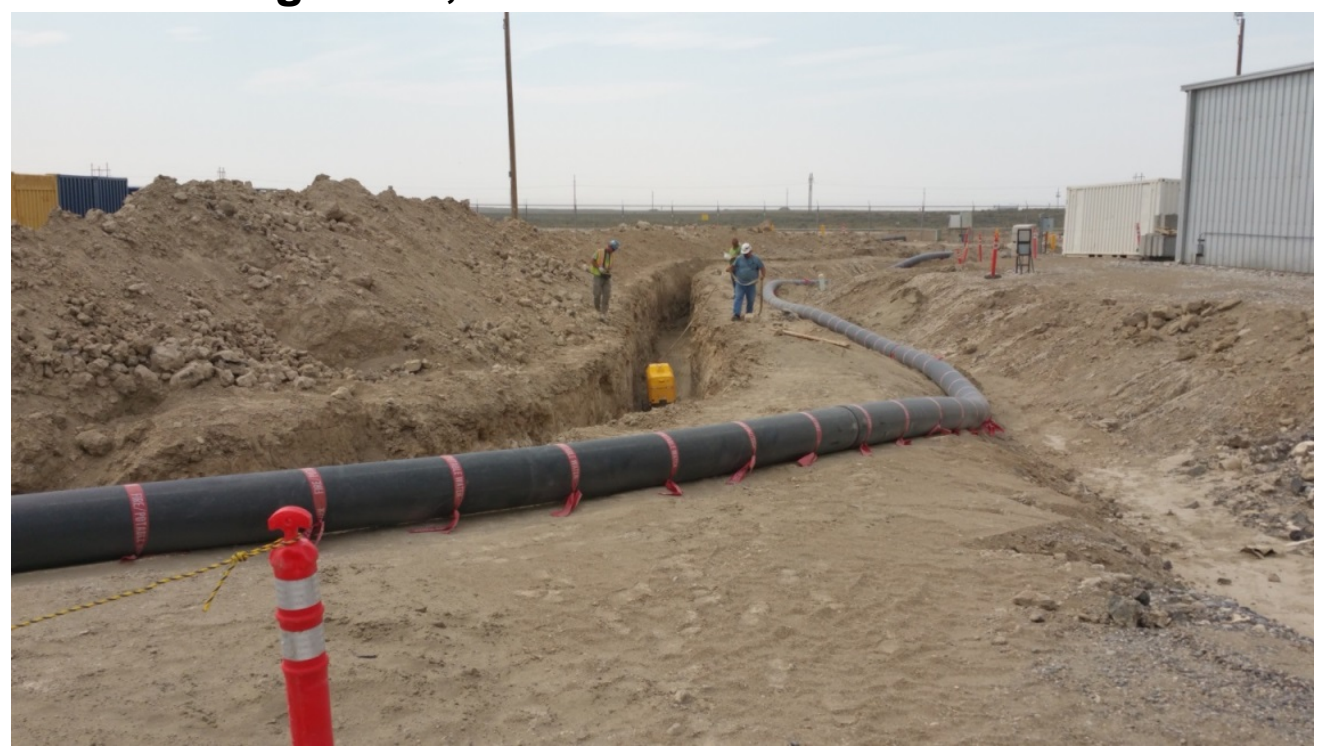

Installation and Compaction of Sand Bed in North Line 
Week of August 24, 2015:

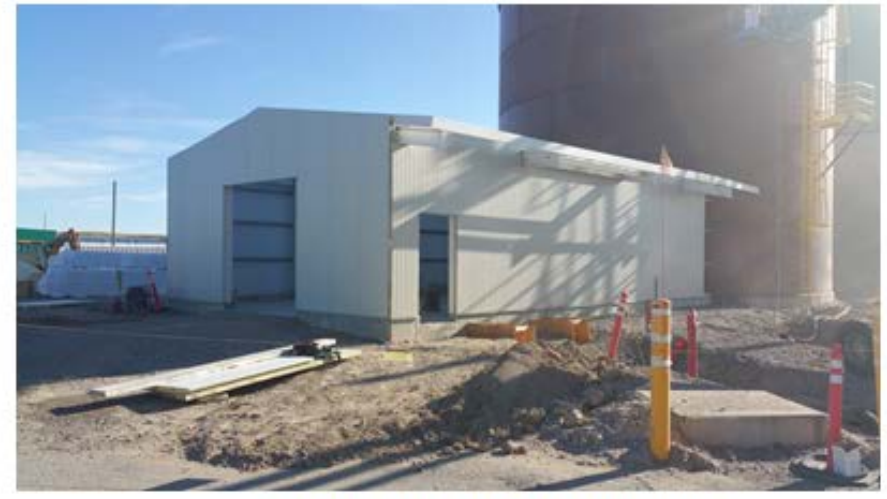

New Pump House - Wall Panel Installation

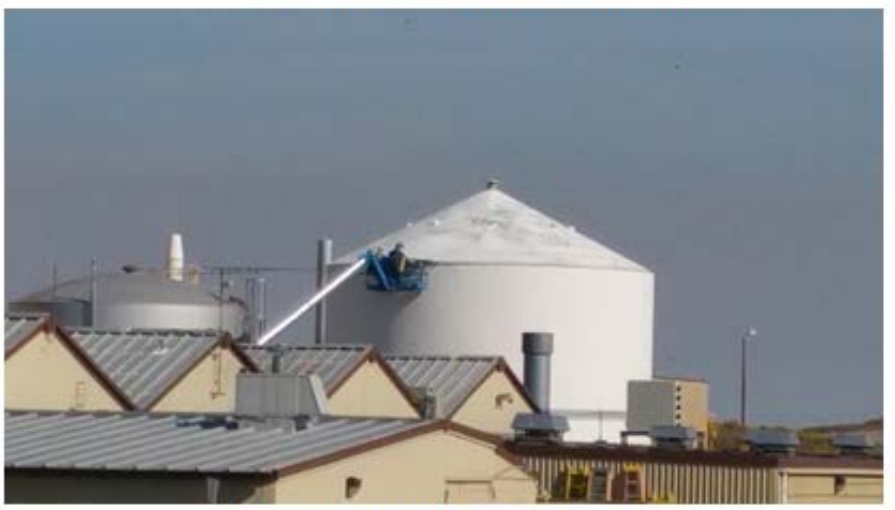

Installation of Insulation Clips on Old Tank

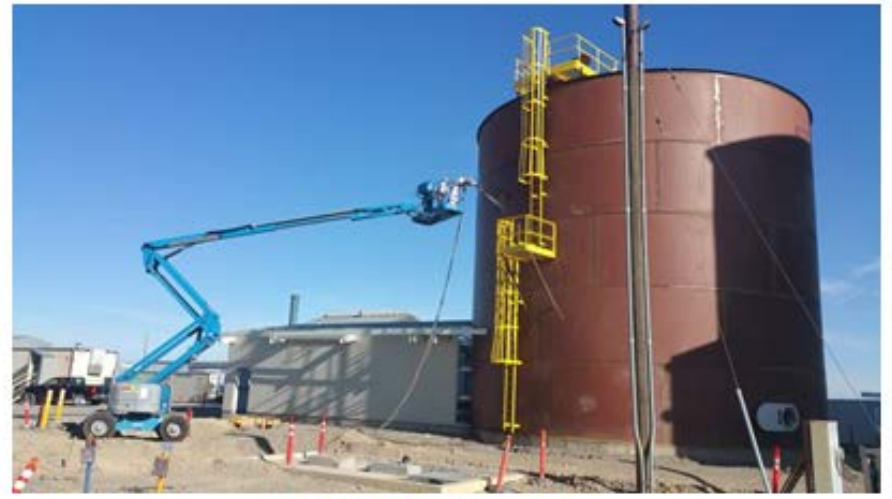

Sand Blasting Tank Exterior

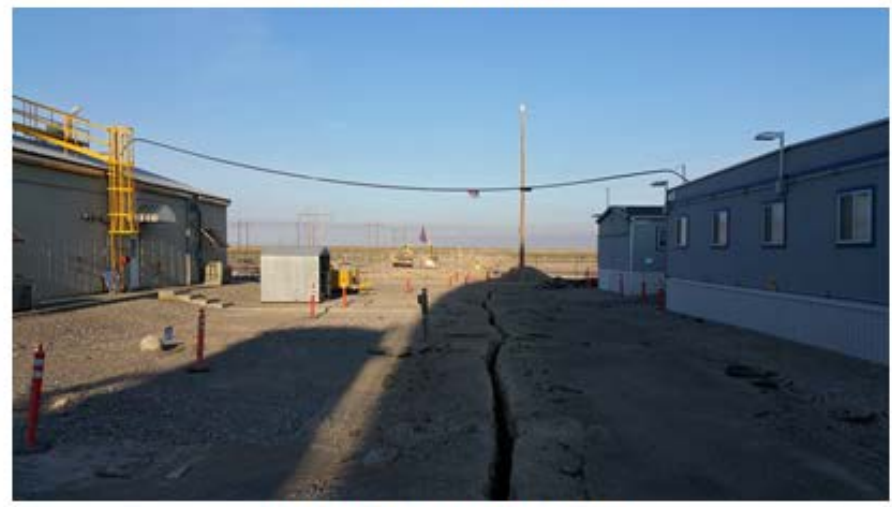

Vacuum Excavation on South Line

\section{Week of August 31, 2015:}

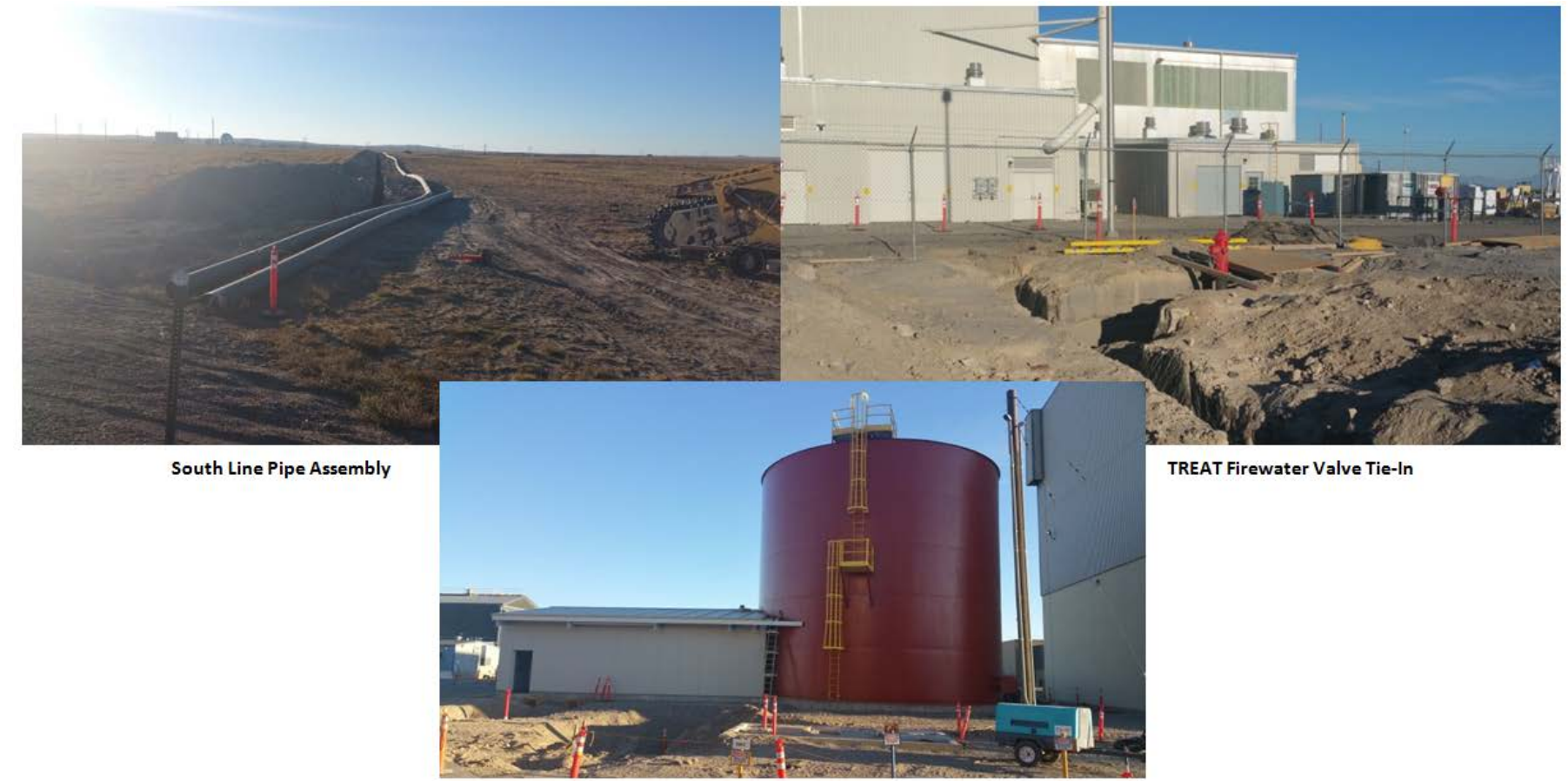

Roof and Wall Installation - Water Tank Primed 
Week of September 7, 2015:

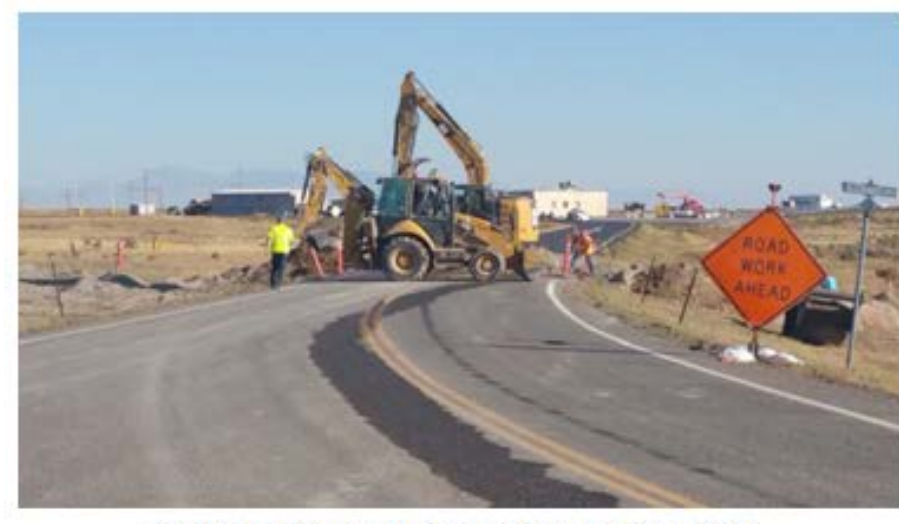

$14^{\prime \prime}$ HDPE Installation Underneath Main Road to TREAT

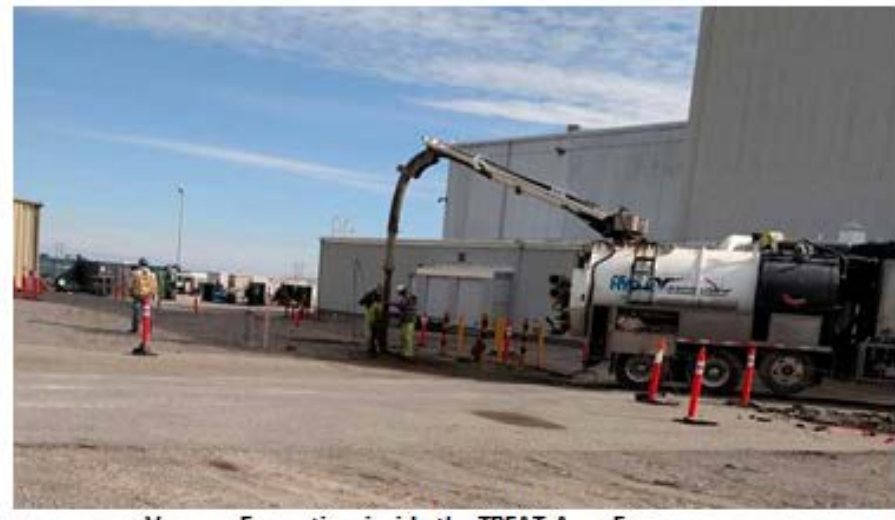

Vacuum Excavation inside the TREAT Area Fence

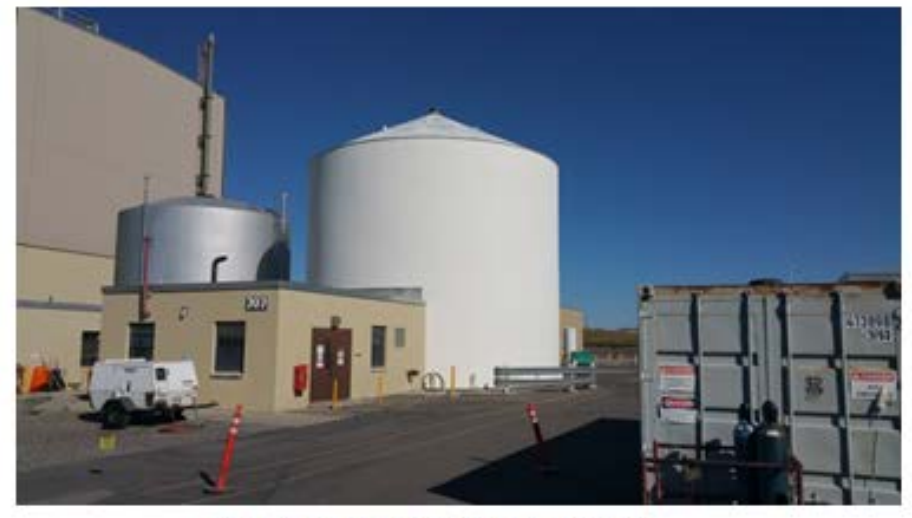

Preparation of Tank Exterior - Old Tank

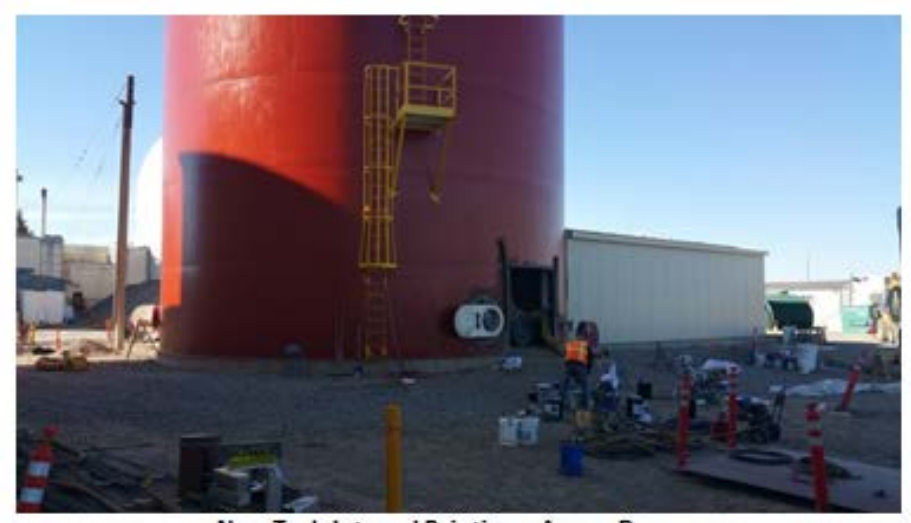

New Tank Internal Painting - Access Door 
Week of September 14, 2015:

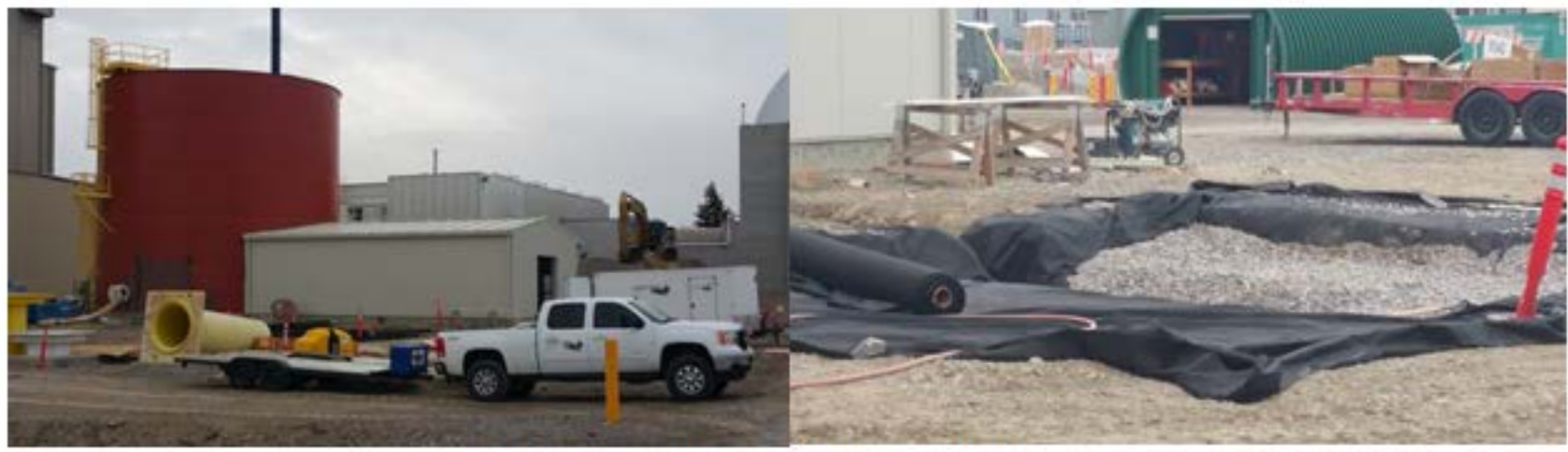

Pump House Trim, Drain Field, and Tie-Ins
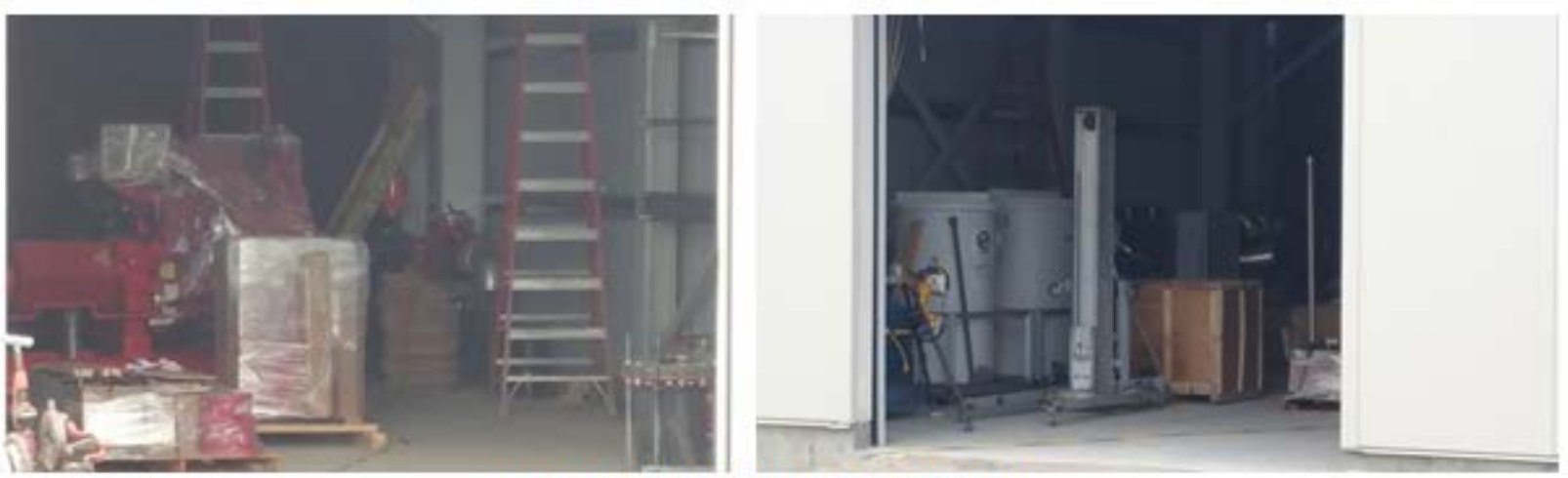

Pump House Electrical and Mechanical

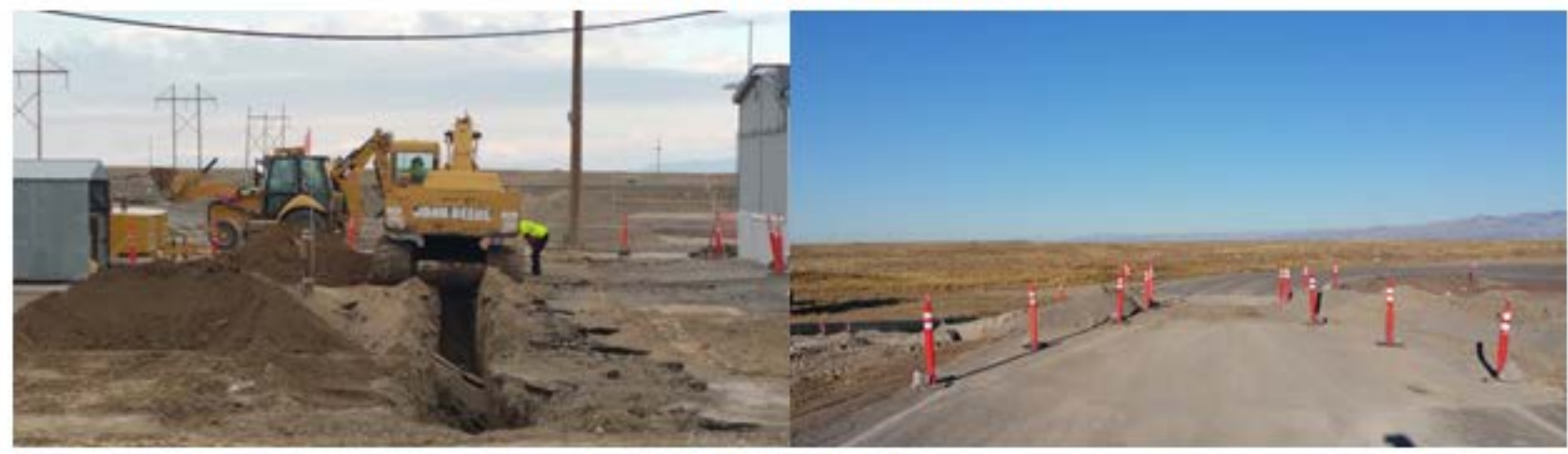

South Line Trenching

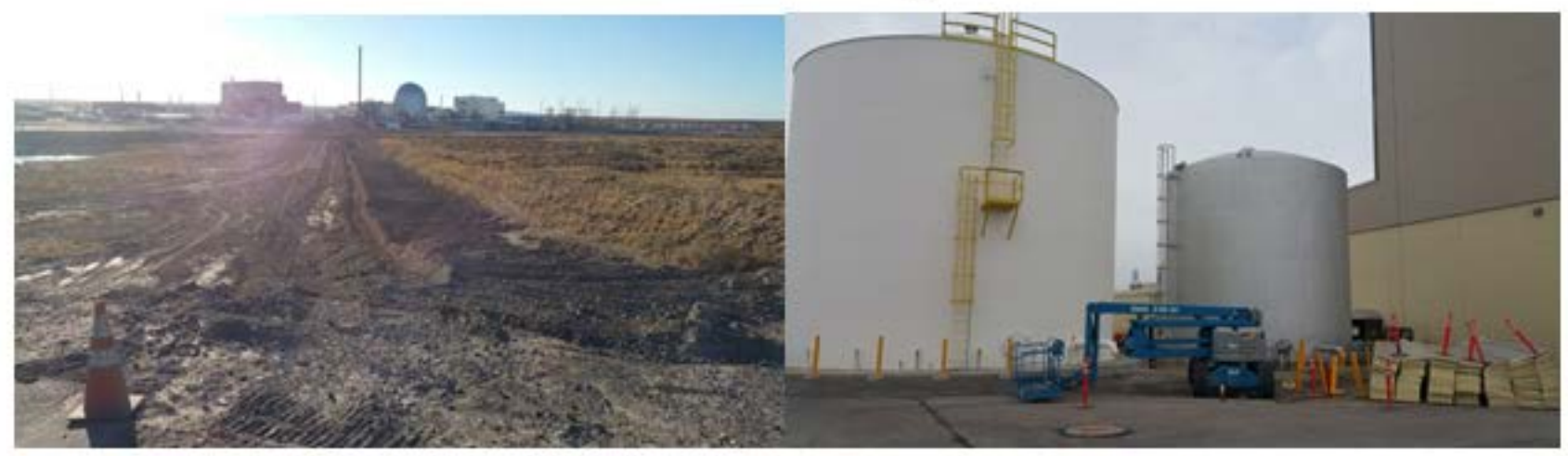


Week of September 21, 2015:

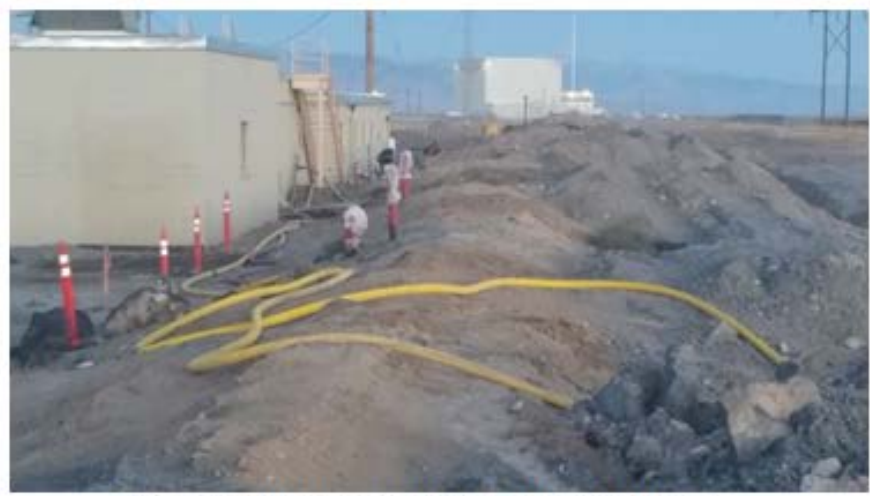

Temporary Water Supply from North Line to MFC-724

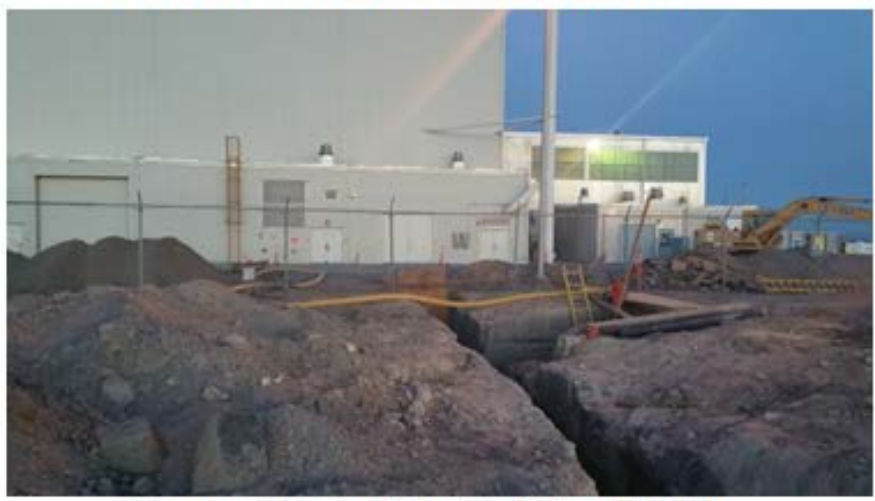

Temporary Water Supply from North Line to MFC-720

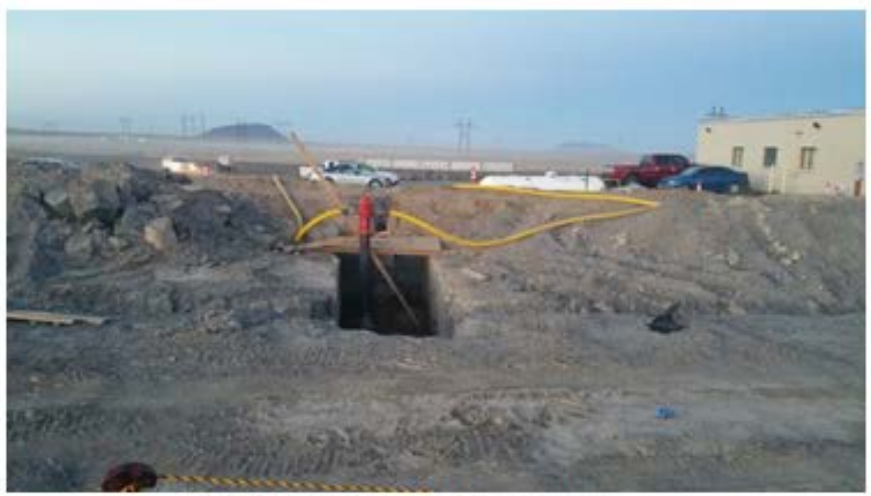

Temporary Water Supply Connections

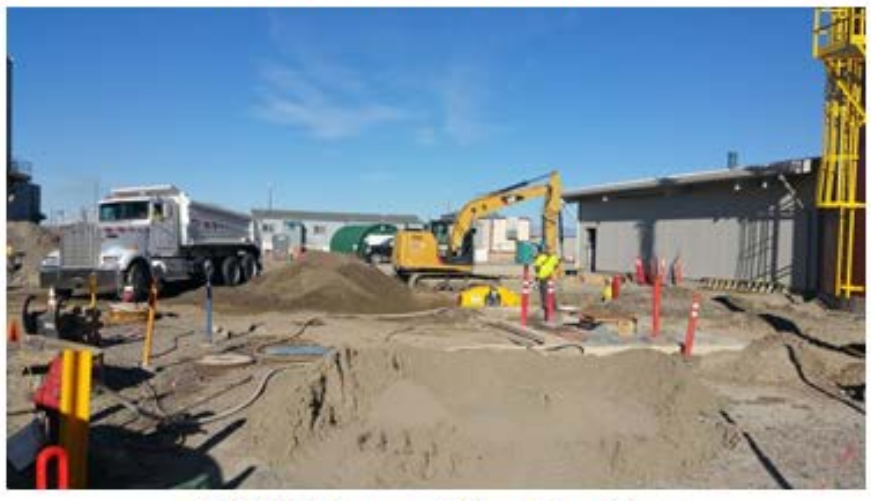

Backfill of Permanent Tie-ins at Pump House

Week of September 28, 2015: 


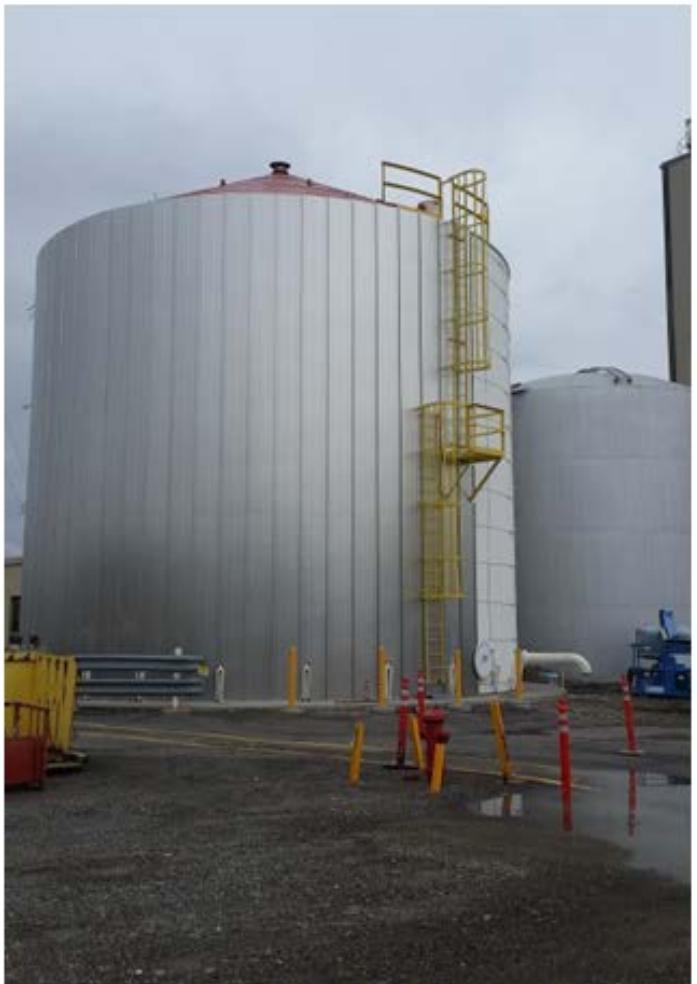

Insulation on Old 400,000 Gallon Tank
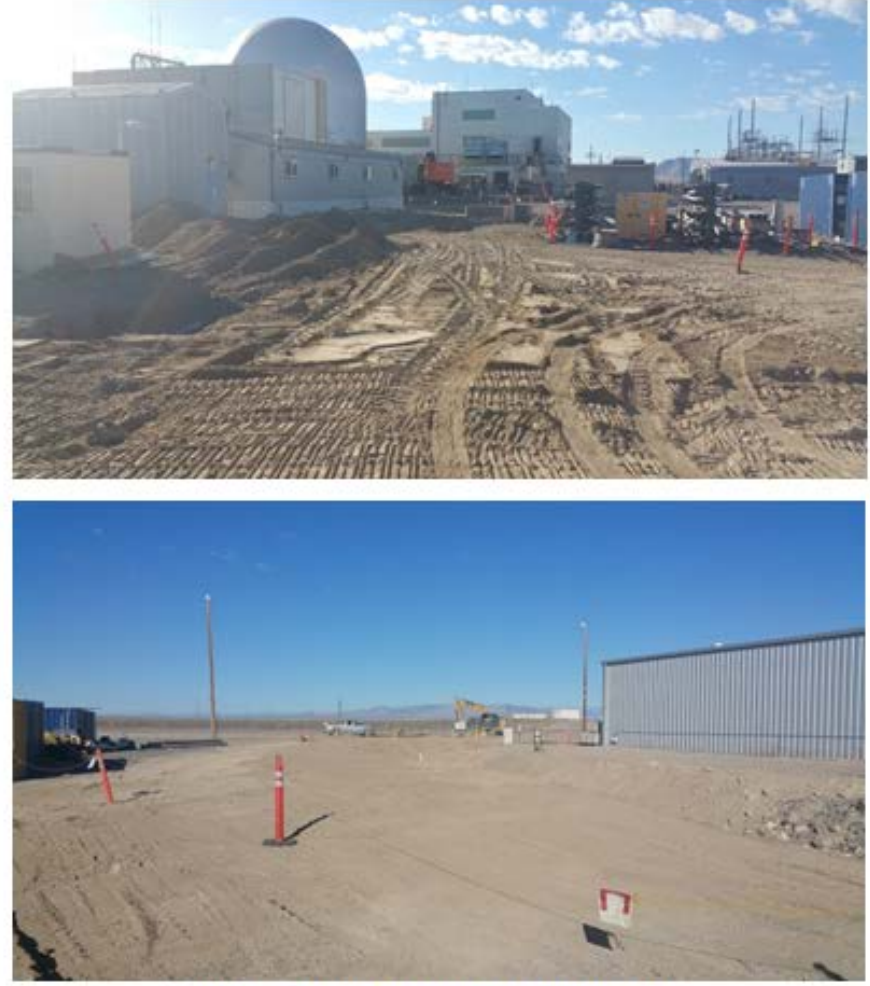

Backfill and Grading along the North Line 


\section{Week of October 5, 2015:}

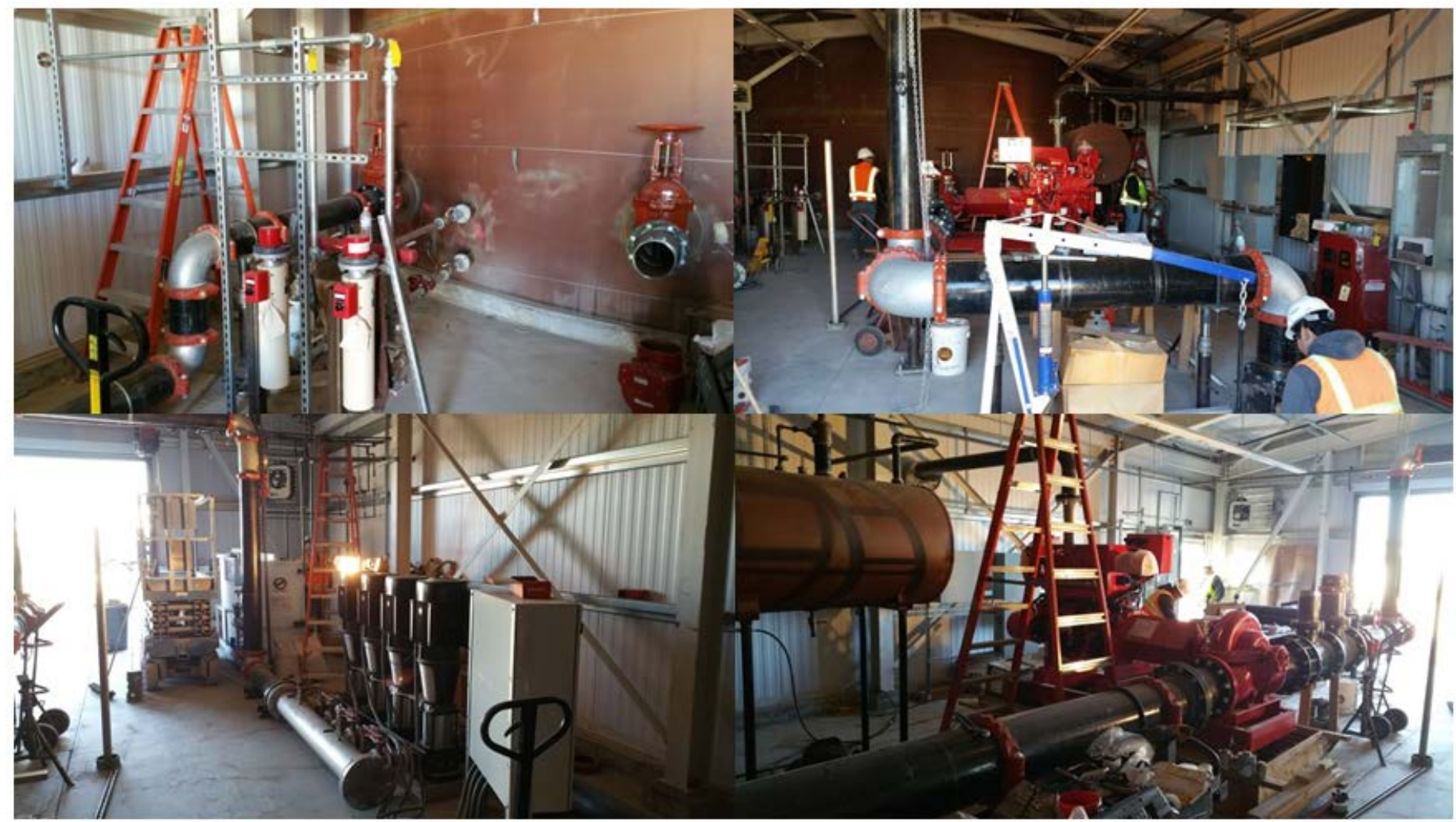

Installation of Electrical and Mechanical in the Pump House

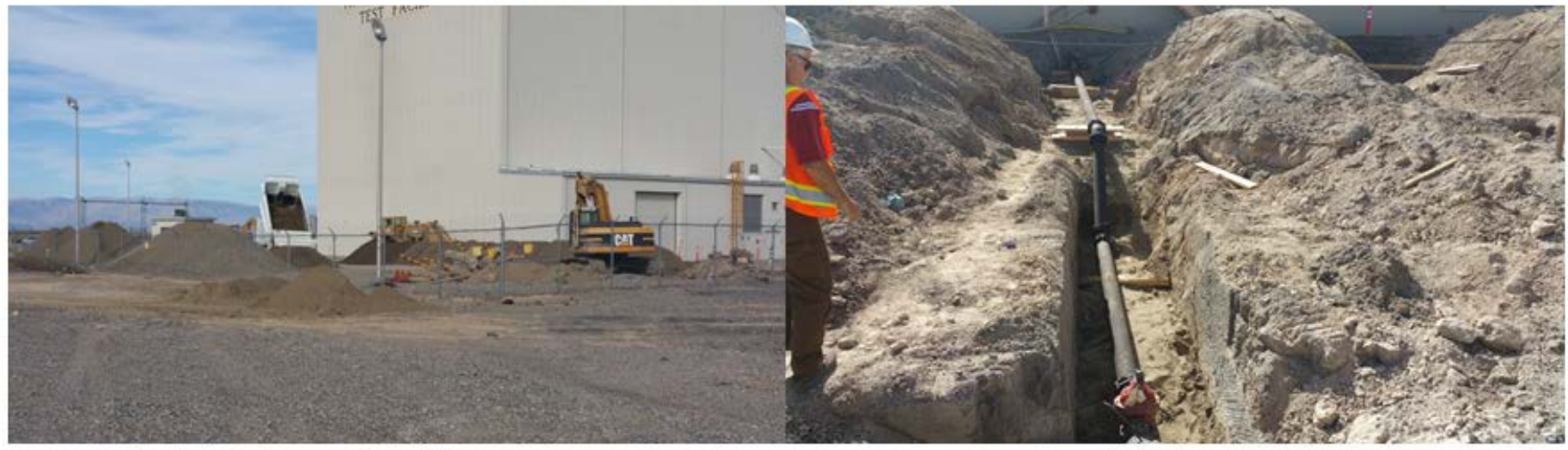




\section{Week of October 12, 2015:}

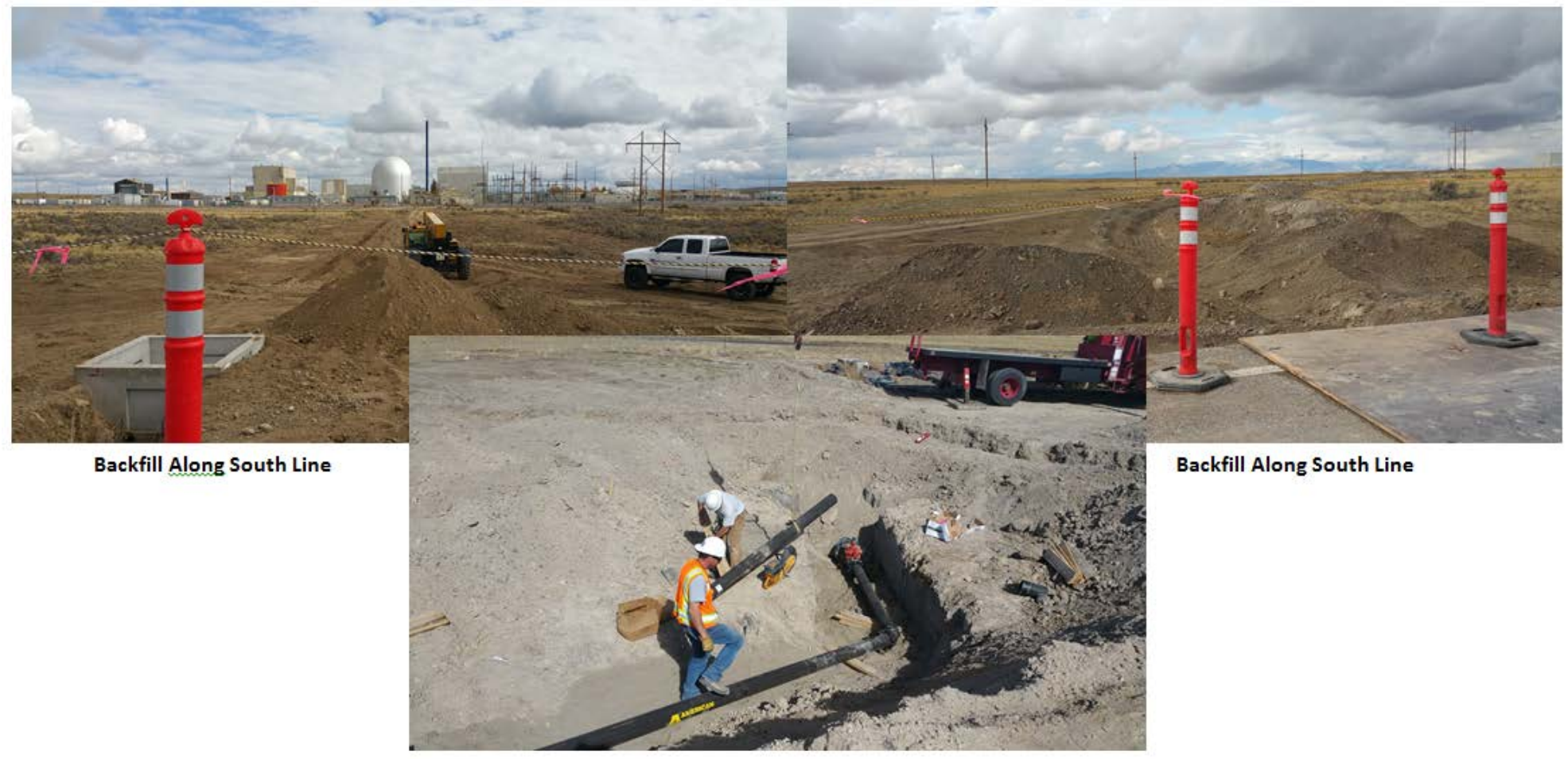

Tie-in from North Line

Week of October 19, 2015:

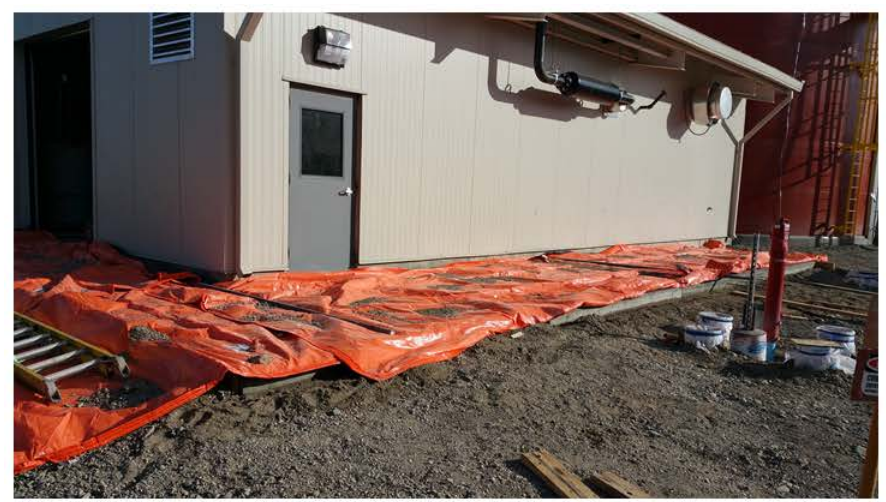

Sidewalks around Pump House

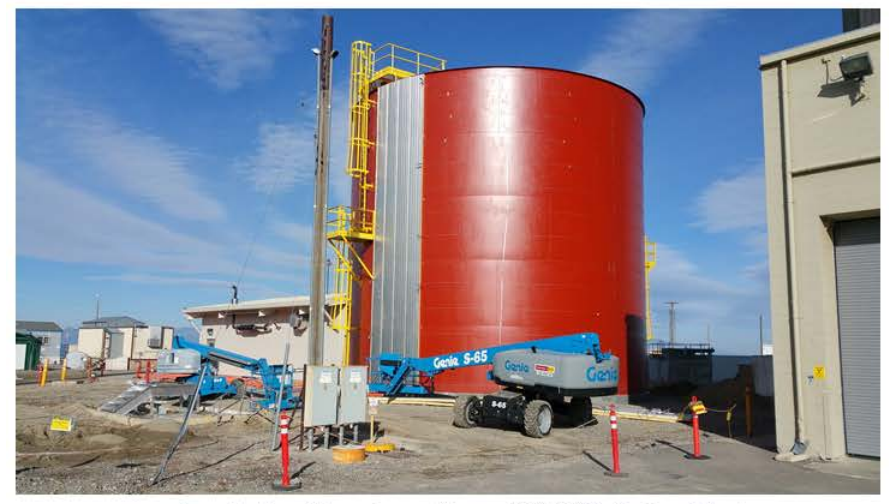

Insulation Panels on New 400,000 Gallon Tank

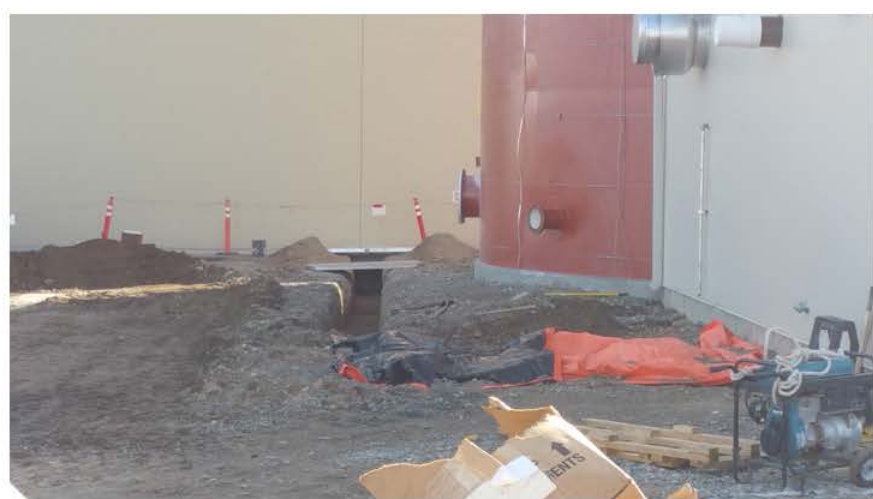

Duct Bank North of Pump House

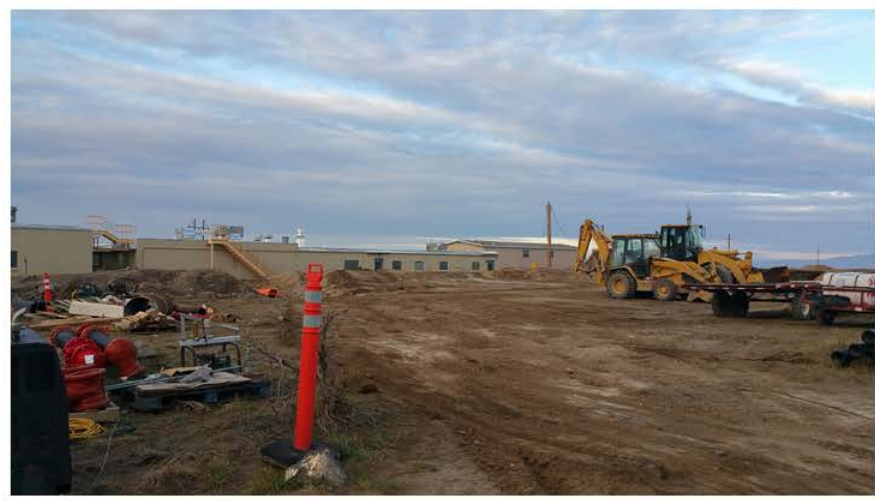

Backfill North of MFC-724 \& MFC-721 


\section{Week of October 26, 2015:}

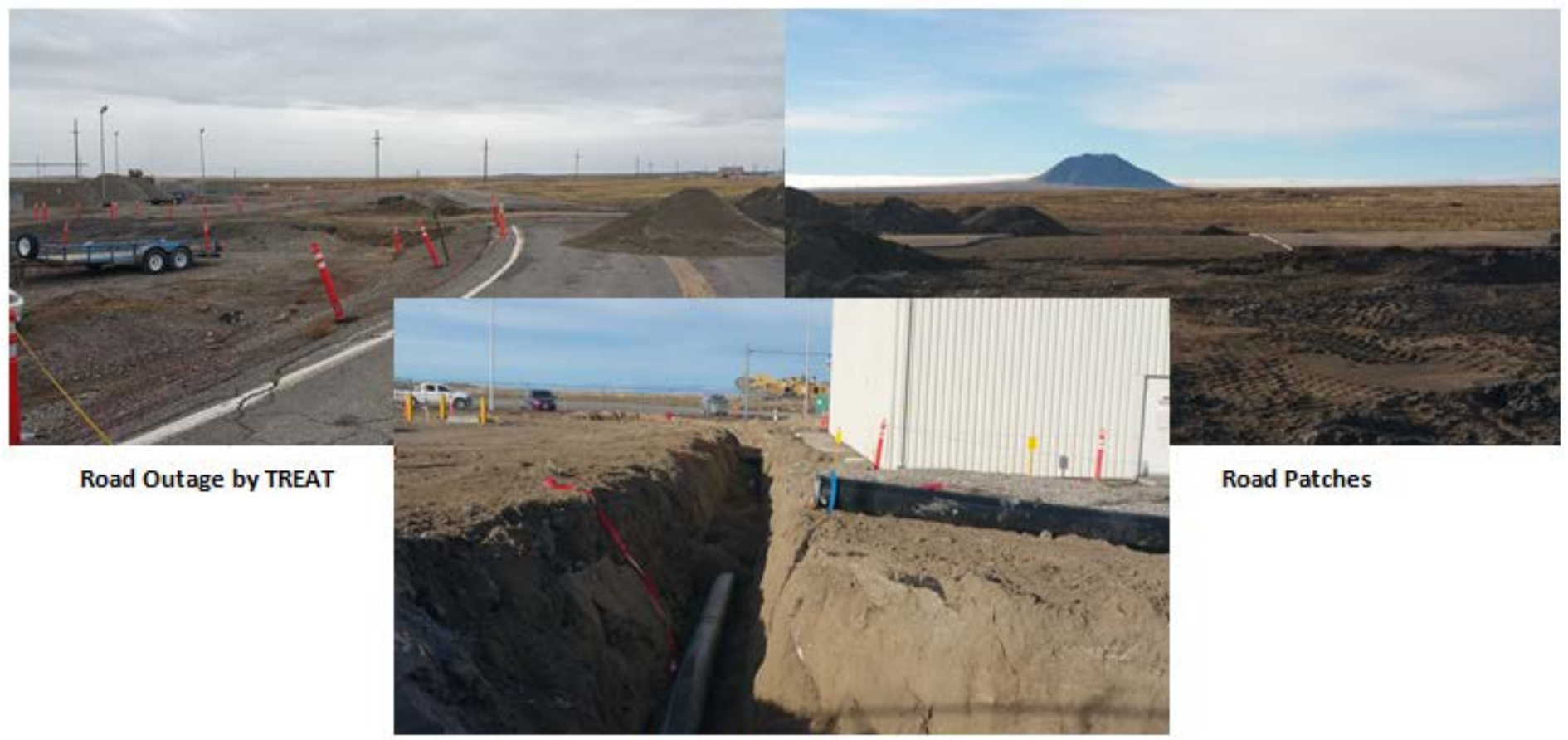

Pipelines in TREAT Area 


\section{Week of November 2, 2015:}

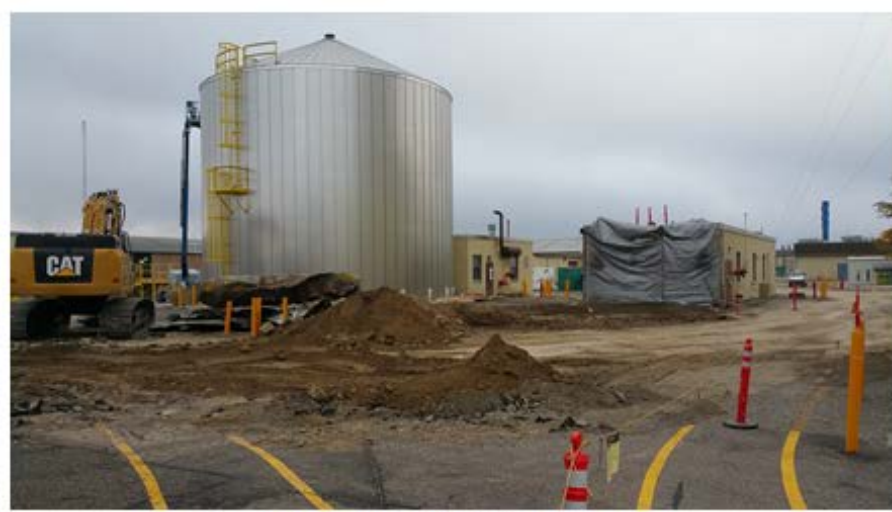

Demolition of the 200,000 Gallon Tank

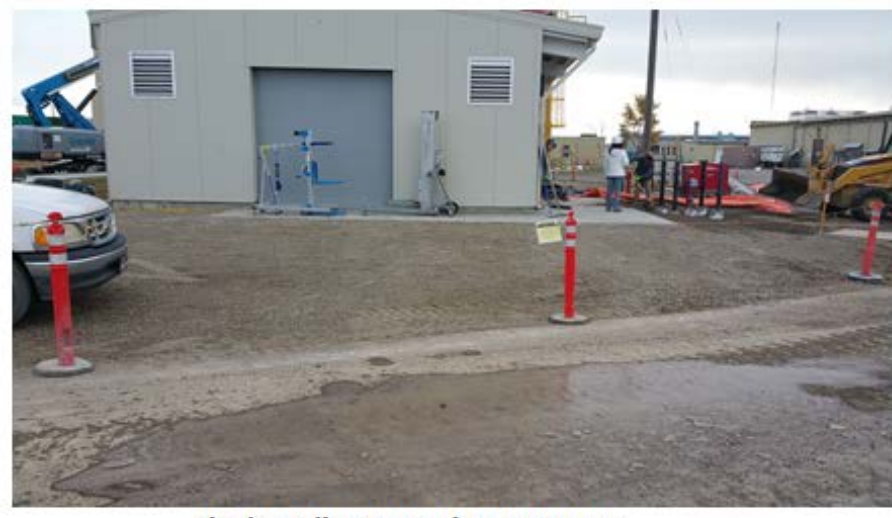

Final Grading Around Pump House

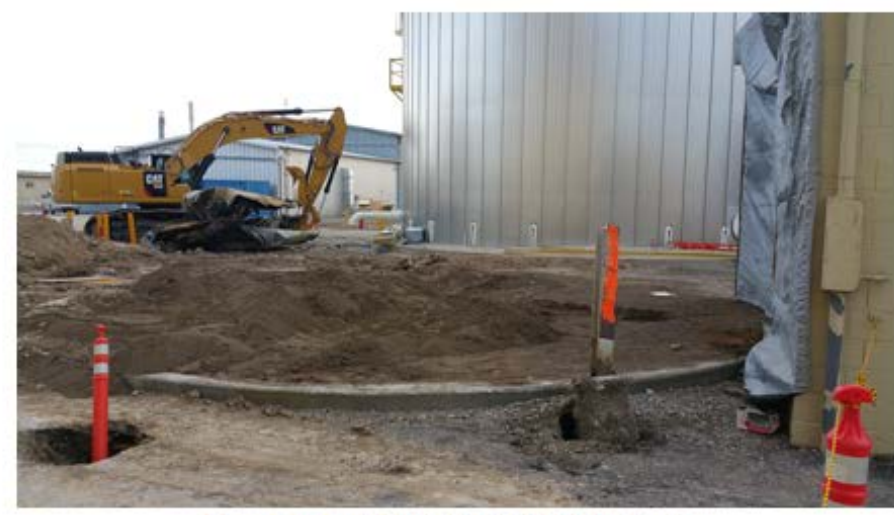

Demolition of the 200,000 Gallon Tank

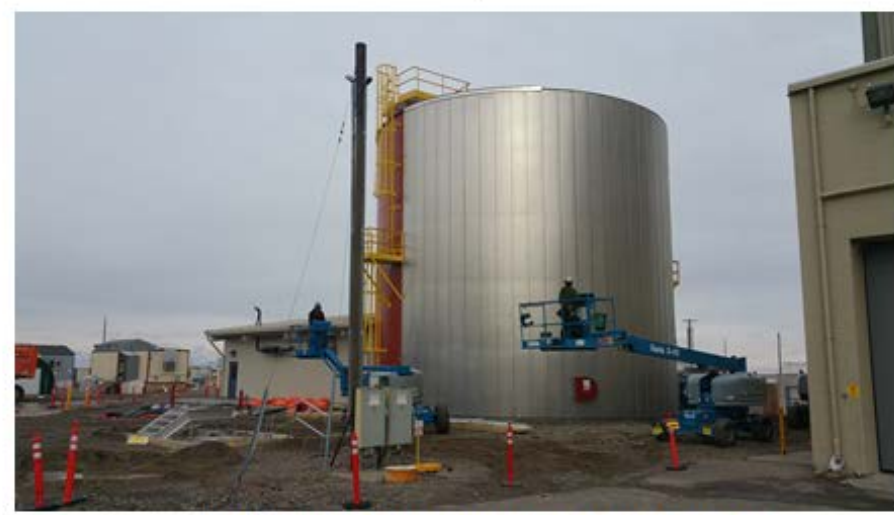

Installation of Insulation Panels on New Tank

Week of November 9, 2015:

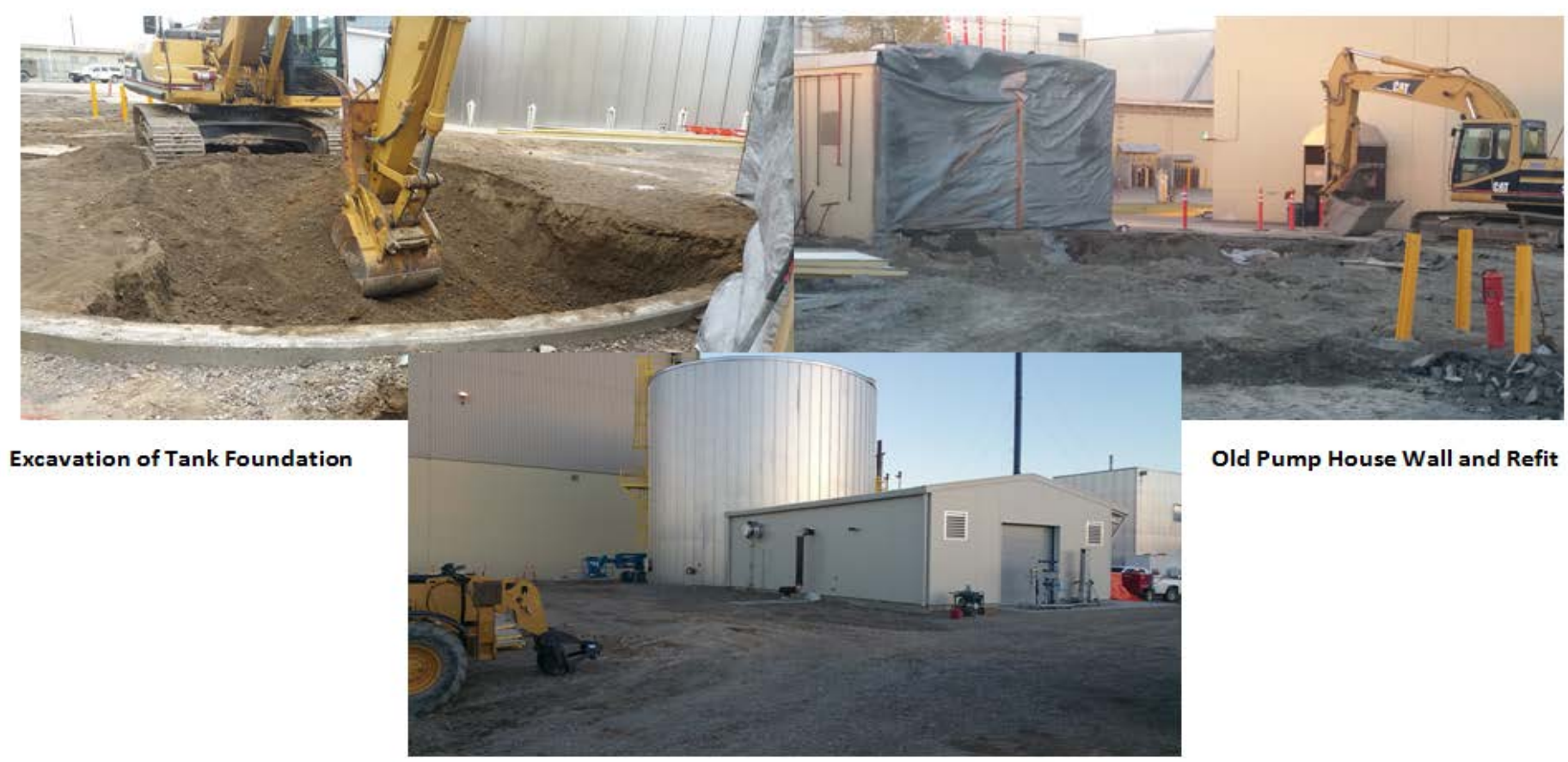

New Tank and Pump House 
Week of November 16, 2015:

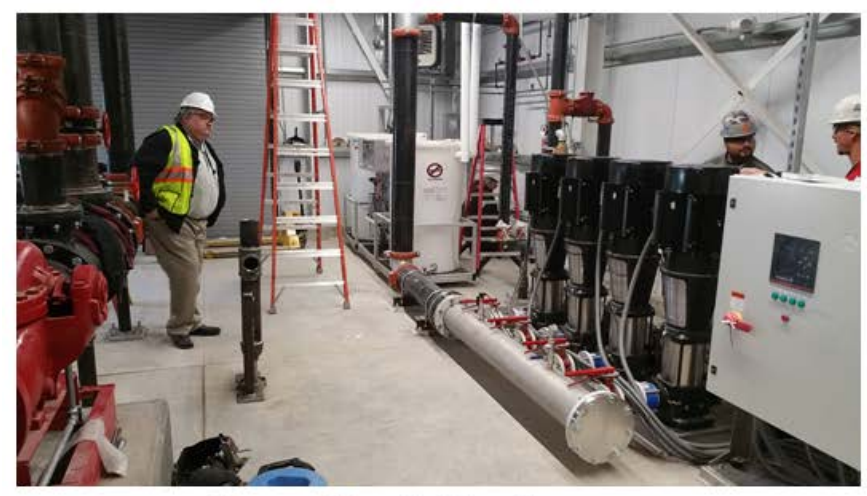

Startup of Potable Water Pumps

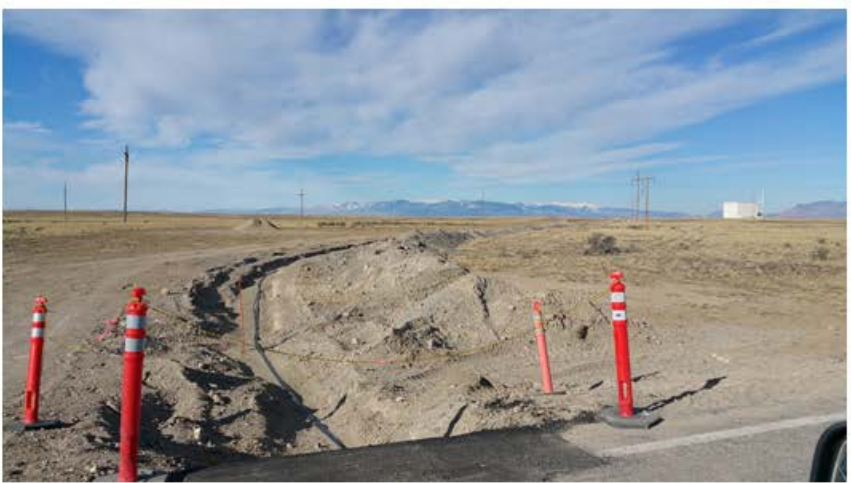

Fiber in South Line Trench

Week of November 23, 2015:

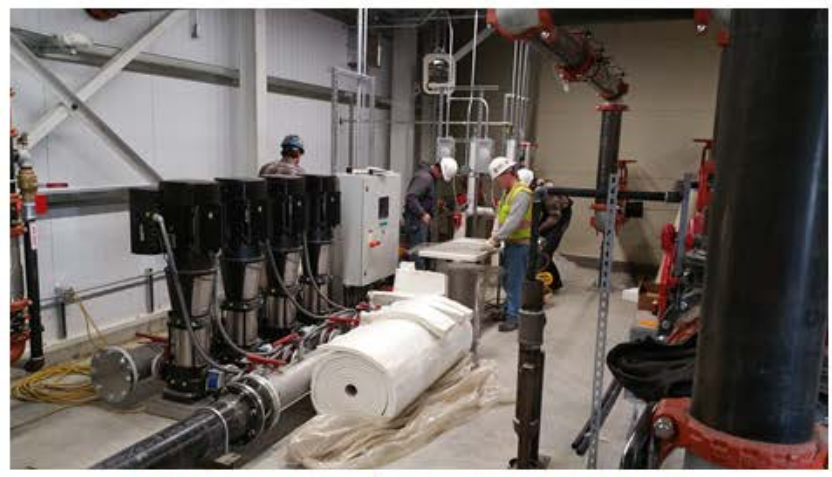

Potable Water Pumps/Insulation of Tank Heaters

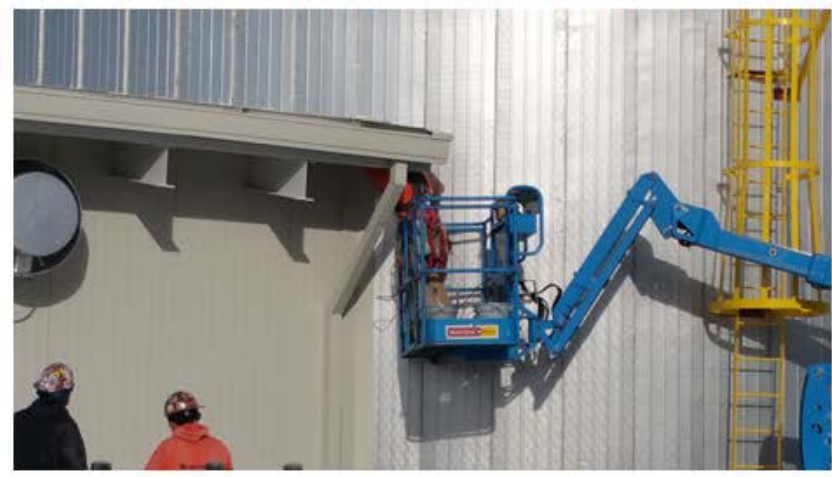

Completion of Punch List Items

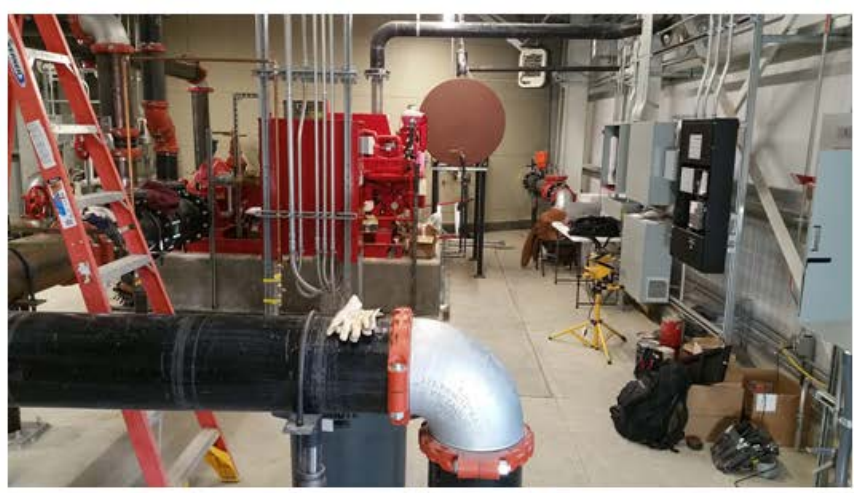

New Pump House Electrical \& Mechanical

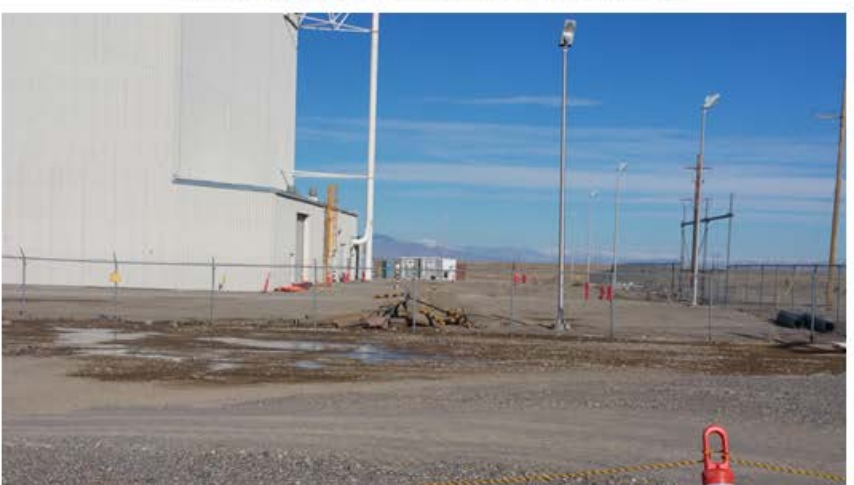

Backfill of South and East Lines at TREAT

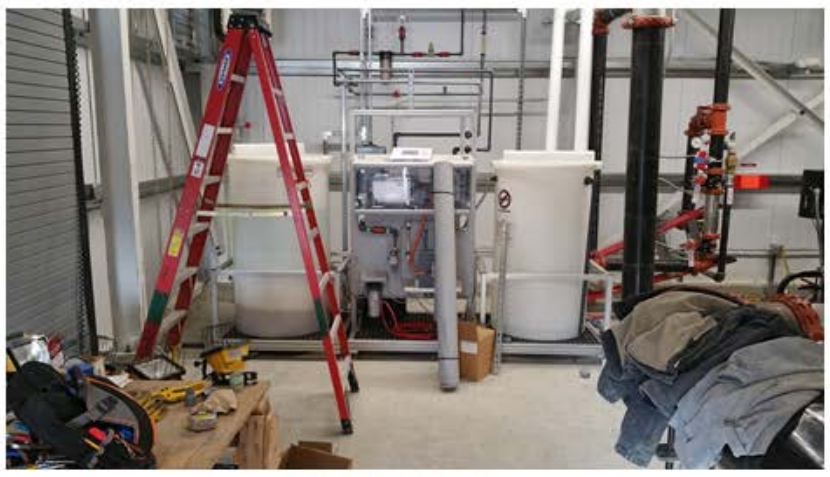

New Miox System

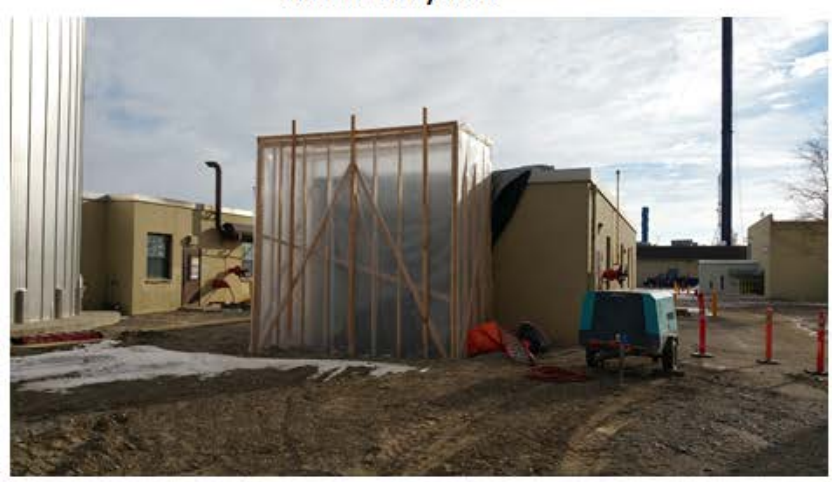

Old Pump House Refit 
Week of November 30, 2015:

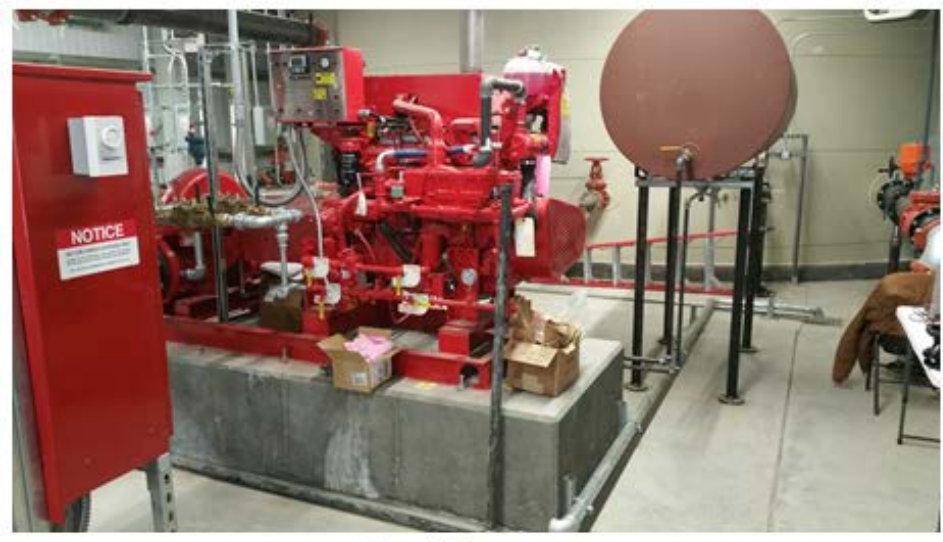

New Diesel Firewater Pump

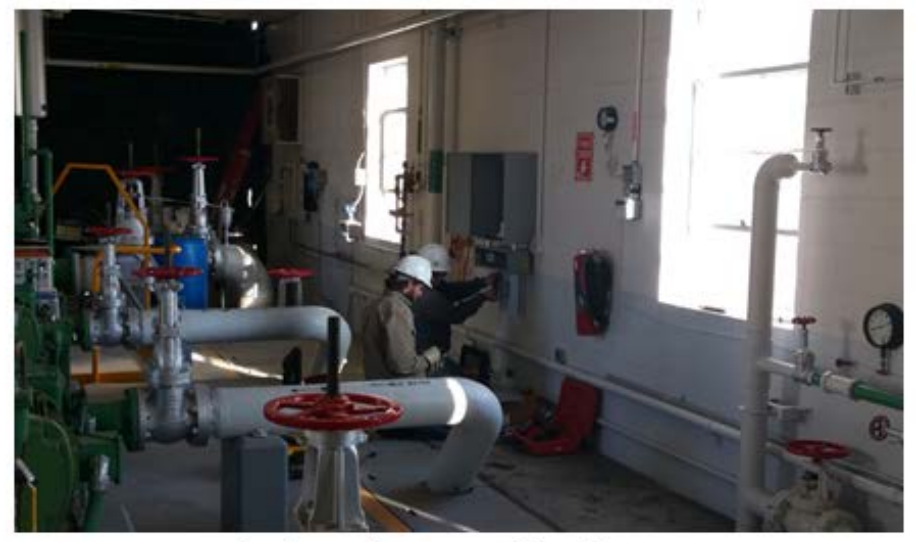

Communications Infrastructure in Old Pump House

Firewater Pump Impeller - February 2016

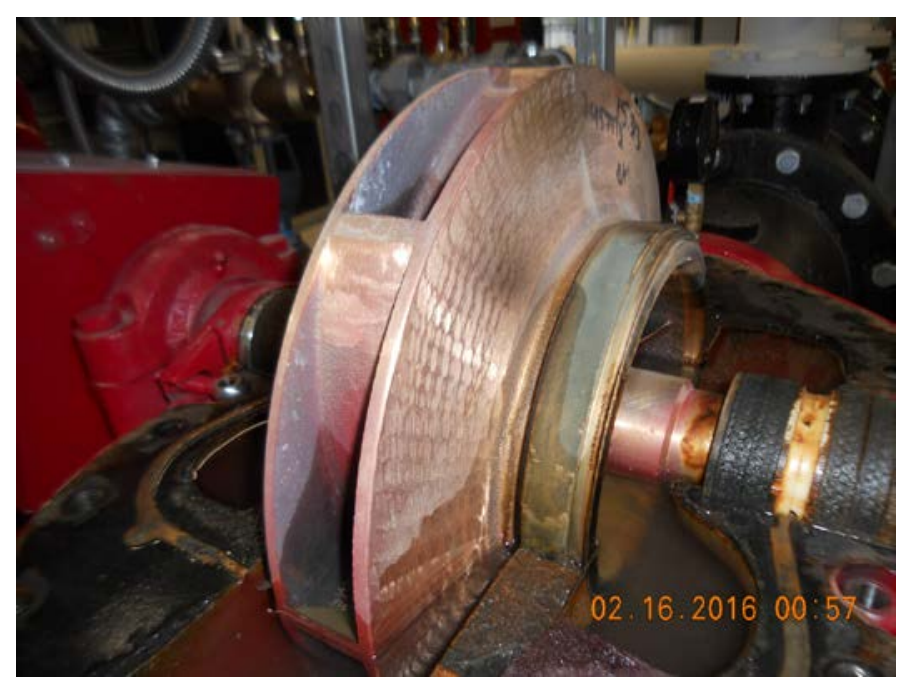

Firewater Pump Casing - February 2016

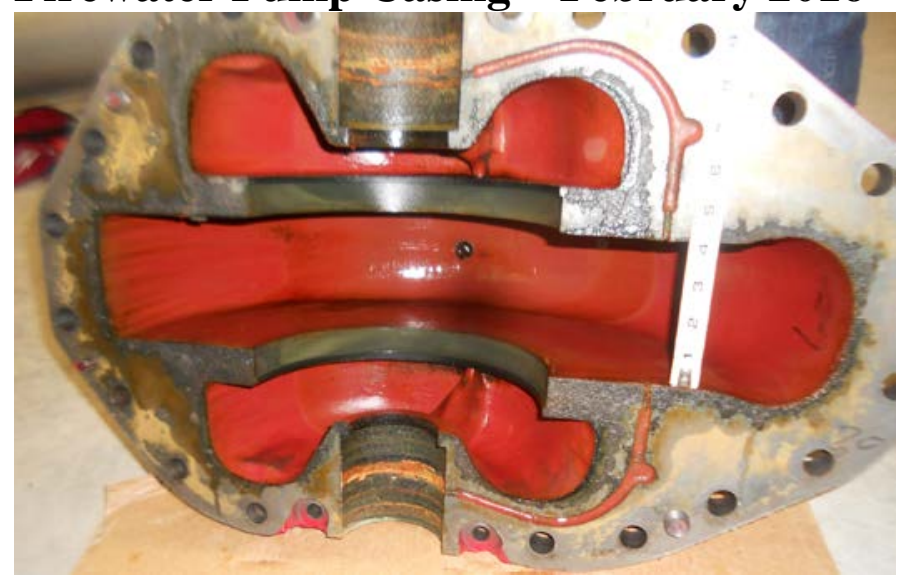


Appendix C,

Master Budget Log 
$\left(\mathrm{PBB}=\mathrm{UB}+\sum \mathrm{CAs}+\sum \mathrm{SLPPs}+\mathrm{MR}+\mathrm{AUW}\right)$

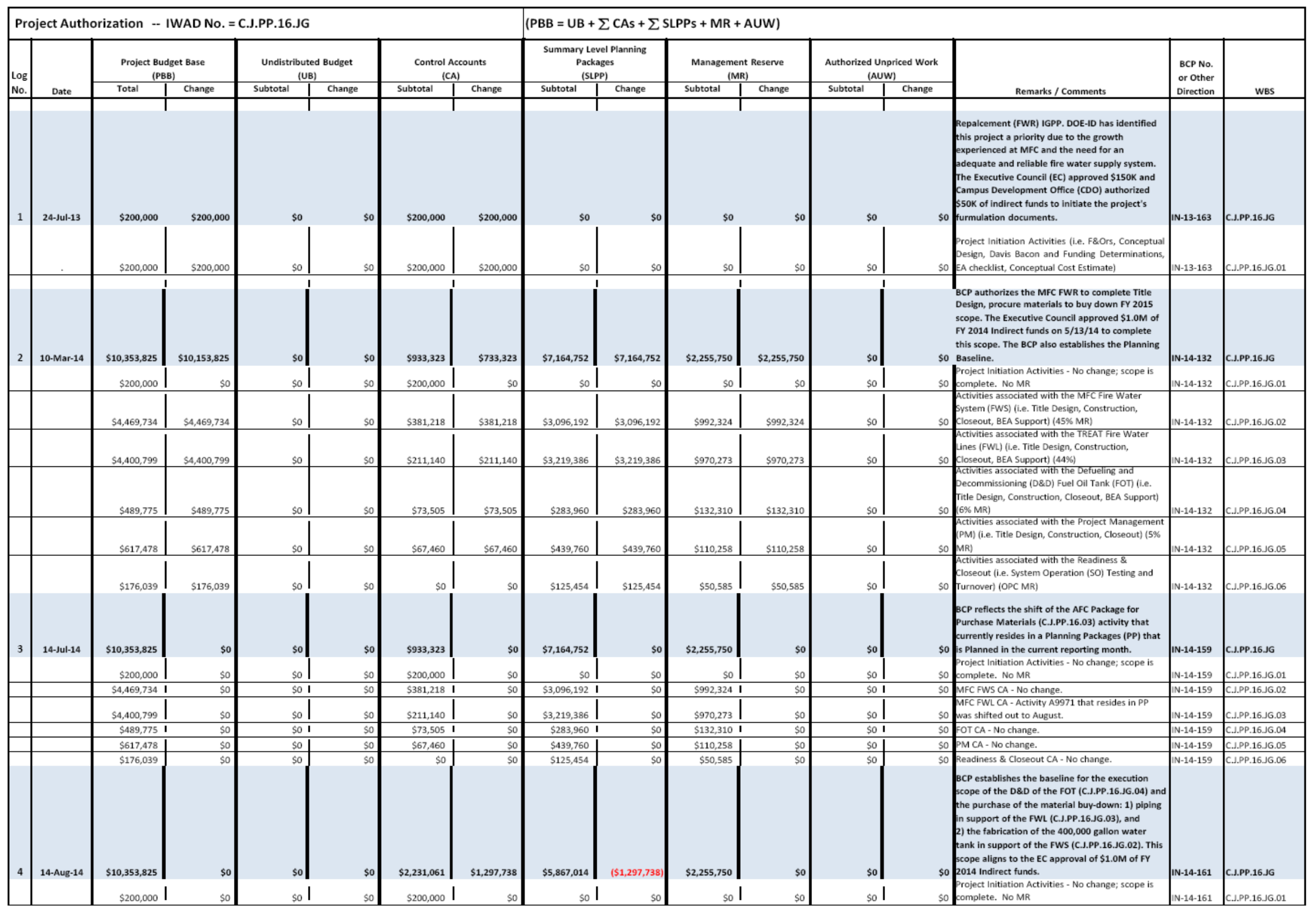




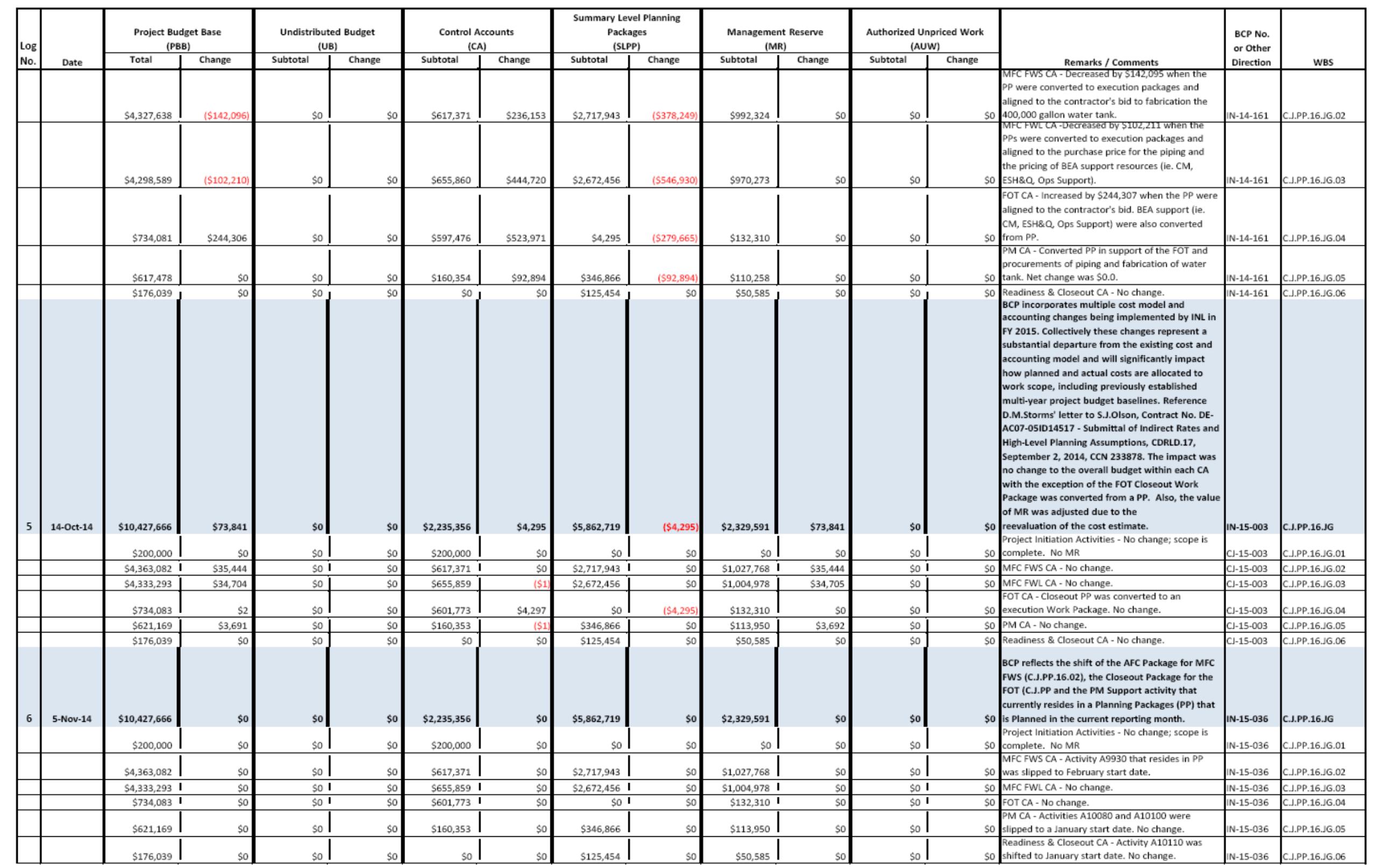




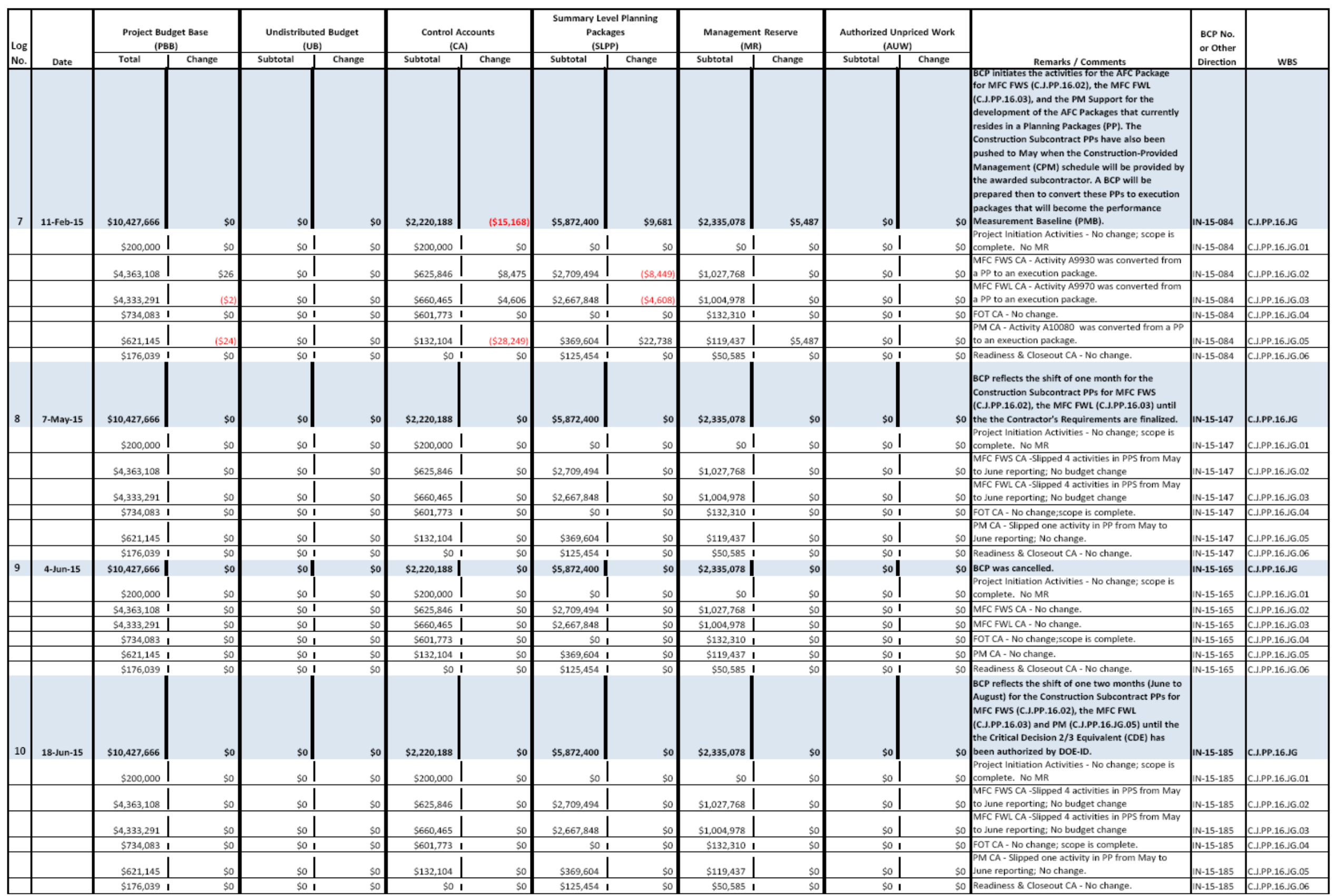




\begin{tabular}{|c|c|c|c|c|c|c|c|c|c|c|c|c|c|c|c|c|}
\hline \multirow{2}{*}{ Log } & \multirow[b]{2}{*}{ Date } & \multicolumn{2}{|c|}{$\begin{array}{l}\text { Project Budget Base } \\
\text { (PBB) }\end{array}$} & \multicolumn{2}{|c|}{$\begin{array}{l}\text { Undistributed Budget } \\
\text { (UB) }\end{array}$} & \multicolumn{2}{|c|}{$\begin{array}{l}\text { Control Accounts } \\
\text { (CA) }\end{array}$} & \multicolumn{2}{|c|}{$\begin{array}{l}\text { Summary Level Planning } \\
\text { Packages } \\
\text { (SLPP) } \\
\end{array}$} & \multicolumn{2}{|c|}{$\begin{array}{l}\text { Management Reserve } \\
\text { (MR) }\end{array}$} & \multicolumn{2}{|c|}{$\begin{array}{l}\text { Authorized Unpriced Work } \\
\text { (AUW) }\end{array}$} & \multirow[b]{2}{*}{ Remarks / Comments } & \multirow{2}{*}{$\begin{array}{l}\text { BCP No. } \\
\text { or Other } \\
\text { Direction }\end{array}$} & \multirow[b]{2}{*}{ was } \\
\hline & & Total & Change & Subtotal & Change & Subtotal & Change & Subtotal & Change & Subtotal & Change & Subtotal & Change & & & \\
\hline \multirow[t]{6}{*}{11} & 6-Jul-15 & $\$ 9,232,622$ & $(\$ 1,195,044)$ & sol & so & $\$ 8,383,215$ & $\$ 6,163,027$ & $\$ 160,640$ & $(\$ 5,711,760)$ & $\$ 688,767$ & $(\$ 1,646,311)$ & \$0 & so & $\begin{array}{l}\text { On May 18, 2015, BEA was approved to proceed } \\
\text { with construction activities for the project (IFM- } \\
\text { 15-014) and directed to develop and submit a } \\
\text { CDE-2/3 package prior to implementation of the } \\
\text { Performance Measurement Baseline (PMB). This } \\
\text { BCP, submitted in conjunction with the CDE-2/3 } \\
\text { package, converts the planning packages (PPS) for } \\
\text { construction and associated BEA support into } \\
\text { work packages (WPS). Upon approval, it will } \\
\text { establish the PMB for post-CDE-2/3 activities in } \\
\text { the MFC Firewater Replacement Project through } \\
\text { construction. MR was also reduced to the amount } \\
\text { reflected on the risk register. } \\
\text { Project Initiation Activities - No change; scope is }\end{array}$ & IN-15-186 & C.J.PP.16.J6 \\
\hline & & $\$ 200,000$ & $\$ 0$ & so & so & $\$ 200,000$ & so & so & so & so & $\$ 0$ & \$o & so & complete. No MR & IN-15-186 & C.J.PP.16.JG.01 \\
\hline & & $\$ 4,948,289$ & $\$ 585,181$ & sol & sol & $\$ 4,529,830$ & $\$ 3,903,984$ & $\$ 12,886$ & $(\$ 2,696,608)$ & $\$ 405,573$ & $(\$ 622,195)$ & sol & $\$ 0$ & $\begin{array}{l}\text { MFC FWS CA-Conversion of the PPS to WPS in this } \\
\text { BCP is based on the schedule of values (SOVS) } \\
\text { contained in a construction contract (CONRACT } \\
\text { NO. 154606) awarded to North Wind Services' on } \\
\text { O4/21/15. }\end{array}$ & |N-15-186 & C.J.PP.16.JG.02 \\
\hline & & $\$ 2,922,269$ & $(\$ 1,411,022)$ & sol & sol & $\$ 2,673,336$ & $\$ 2,012,871$ & $\$ 10,739$ & $(\$ 2,657,109)$ & $\$ 238,194$ & $(\$ 766,784)$ & \$o & so & $\begin{array}{l}\text { MFCFWLCA-Conversion of the PPS to WPS in this } \\
\text { BCP is based on the schedule of values (SOVs) } \\
\text { contained in a construction contract (CONTRACT } \\
\text { No. 154606) awarded to North Wind Services' on } \\
\text { O4/21/15. }\end{array}$ & |N-15-186 & C.J.PP. $16 . J 6.03$ \\
\hline & & $\$ 601,773$ & $(\$ 132,310)$ & 501 & so & $\$ 601,773$ & $\$ 0$ & so 1 & $\$ 0$ & (so) I & $(\$ 132,310)$ & so 1 & \$0 & FOT CA - No change; scope is complete. & N-15-186 & C.J.PP.16.JG.04 \\
\hline & & $\$ 389,837$ & $(\$ 231,308)$ & so & sol & $\$ 378,276$ & $\$ 246,172$ & $\$ 11,561$ & $(\$ 358,043)$ & so & $(\$ 119,437)$ & so & sol & $\begin{array}{l}\text { PM CA - PMB contains the BEA activities and } \\
\text { associated resources necessary to complete that } \\
\text { work. }\end{array}$ & IN-15-186 & C.J.PP.16.JG.05 \\
\hline \multirow[t]{5}{*}{12} & 14-Oct-15 & $\$ 170,454$ & $(\$ 5,585)$ & $\$ 0$ & so & $\$ 8,543,856$ & $\$ 160,641$ & $\$ 125,454$ & $(\$ 160,640)$ & $\$ 45,000$ & $(\$ 5,585)$ & $\$ 0$ & \$0 & $\begin{array}{l}\text { Readiness \& Closeout CA - No change. } \\
\text { This BCP converted all the Project Closeout and } \\
\text { PM Closeout planning packages (PPs) into work } \\
\text { packages (WPs). These activities will be planned } \\
\text { to a lower level of detail and allow the testing, } \\
\text { turnover, and closeout scope to start earlier than } \\
\text { originally planned (October rather than } \\
\text { December). This will make the transfer of the } \\
\text { project to operations more effective. The overall } \\
\text { budget and schedule did not change. DOE-ID } \\
\text { approved the PeP that identified a "Post Critican } \\
\text { Decision Equivalant (CDE) -4, "Approve Start of } \\
\text { Operations or Project Completion", therefore this } \\
\text { BCP is internal. }\end{array}$ & N-15-186 & C.J.PP. $16 . J G .06$ \\
\hline & & $\$ 200,000$ & $\$ 0$ & sol & so & $\$ 200,000$ & so & sol & so & so & $\$ 0$ & so & so & $\begin{array}{l}\text { Project Initiation Activities - No change; scope is } \\
\text { complete. No MR }\end{array}$ & IN-16-002 & C.J.PP. $16 . J 6.01$ \\
\hline & & $\$ 4,940,804$ & $(\$ 7,485)$ & sol & sol & $\$ 4,535,231$ & $\$ 5,401$ & sol & $(\$ 12,886)$ & $\$ 405,573$ & so & sol & so & $\begin{array}{l}\text { MFC FWS CA-Conversion of the Closeout PPS to } \\
\text { WPS in this BCP. }\end{array}$ & | $N-16-002$ & C.J.PP. $16 . J 6.02$ \\
\hline & & $\$ 2,927,391$ & $\$ 5,122$ & sol & sol & $\$ 2,689,197$ & $\$ 15,861$ & sol & $(\$ 10,739)$ & $\$ 238,194$ & sol & so & so & $\begin{array}{l}\text { MFC FWLCA-Conversion of the Closeout PPs to } \\
\text { WPS in this BCP. }\end{array}$ & IN-16-002 & C.J.PP.16.JG.03 \\
\hline & & $\$ 601,773$ & $\$ 0$ & \$o I & so & $\$ 601,773$ & so & so 1 & so & (so) 1 & $\$ 0$ & \$o I & so & FOT CA - No change; scope is complete. & IN-16-002 & C.J.PP.16.JG.04 \\
\hline
\end{tabular}




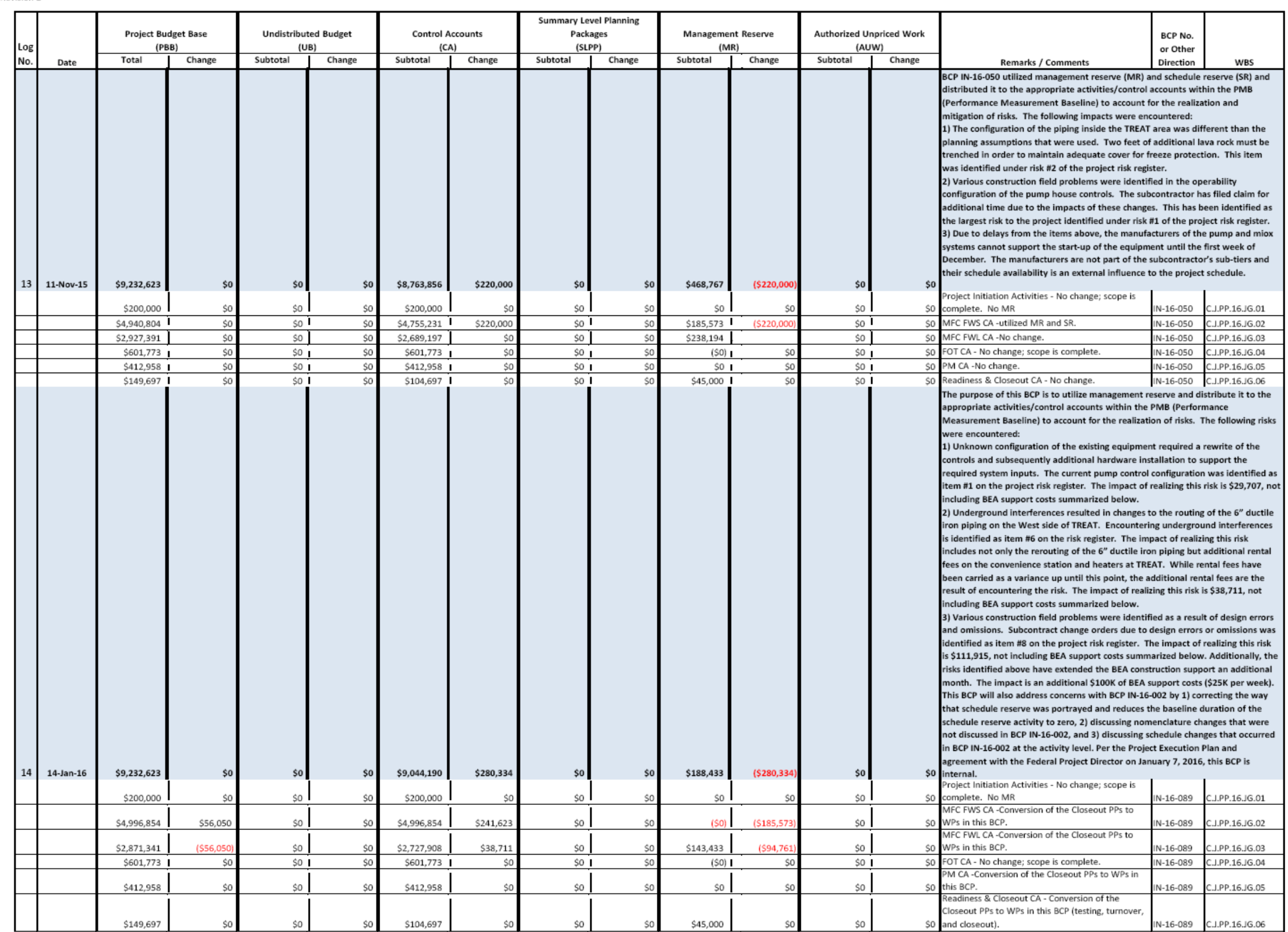


Appendix D,

Project Deficiency Punchlist 


\begin{tabular}{|c|c|c|c|c|c|}
\hline \multicolumn{6}{|c|}{ 432.A36 $\quad$ INL CONSTRUCTION PUNCH LIST } \\
\hline \multirow{2}{*}{\multicolumn{2}{|c|}{$\begin{array}{l}\text { Contract Number: } \\
\text { Contractor: }\end{array}$}} & 154606 (Project\# 31780) & \multirow{2}{*}{\multicolumn{3}{|c|}{$\begin{array}{l}\text { Upgrade } \\
\text { Date: } 5 / 31 / 16\end{array}$}} \\
\hline & & North Wind & & & \\
\hline Item No. & & 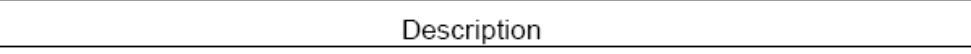 & Generated By & Action By & Date/Initial Complete \\
\hline 1. & Comple & e conduit and panel labels in 1740 & G. Smith & NW & 3-7-16/ K. Cathey \\
\hline 2. & Comple & e piping labels in 1740 (Accept per E. Hallgren email) & E. Hallgren & NW & 3-16-16 / E. Hallgren \\
\hline 3. & Fire pur & p crank case is vented to room (CFP-213) & D. Diaz & $\mathrm{BEA} / \mathrm{NW}$ & 2-15-16 / R.Lee \\
\hline 4. & Packing & on fire pump is leaking more than it should (repair) & B. Jorgensen & NW & 2-4-16 / R.Lee \\
\hline 5. & Adjust $\mathrm{r}$ & anual tank level gage to read the same as the auto gage & B. Jorgensen & NW & 2-25-16 / Z. Mickelsen \\
\hline 6. & Remov & blind flange from distribution piping & D. Clark & NW & 4-5-16 / R. Lee \\
\hline 7. & Install a & cover on the fire pump batteries (Accept per E. Hallgren email) & E. Hallgren & NW & 4-5-16 / E. Hallgren \\
\hline 8. & Numbe & one service water pump is squealing (repair) & B. Jorgensen & NW & 2-4-16/R.Lee \\
\hline 9. & $\begin{array}{l}\text { Diesel f } \\
\text { accept }\end{array}$ & $\begin{array}{l}\text { lel tank has a fill issue that needs resolved (Facility agreed to remove filter and } \\
\text { Is is) }\end{array}$ & B. Jorgensen & NW & 4-20-16/ R. Lee \\
\hline 10. & Install c & over on roll up door motor (Deleted per CFP-205) & R. Carbiener & NW & 2-4-16 / R.Lee \\
\hline 11. & Fire Ala & $\mathrm{m}$ panel needs programed so all fire pump monitoring is a supervisory signal & D. Clark & NW & 2-4-16 / R.Lee \\
\hline 12. & Install $p$ & astic covers on bollards by $788,754,721 \& 720$ & R. Lee & NW & 2-17-16/R. Lee \\
\hline 13. & Install s & reen on 1740 tank overflow pipe (CFP-212) & E. Hallgren & NW/BEA & 3-9-16/R. Lee \\
\hline 14. & Insulate & miox injection pipe by south east unit heater (CFP-202) & R. Heyrend & NW/BEA & 2-15-16/R. Lee \\
\hline 15. & Install s & upport on miox injection pipe by south unit heater ( CFP-202) & R. Heyrend & NW & 2-15-16/R. Lee \\
\hline 16. & Repair & round wire north of 756 pump house & D. Kelly & NW & 2-4-16 / R.Lee \\
\hline 17. & Repair & round ring at 723 & D. Kelly & NW & 2-4-16/R.Lee \\
\hline 18. & Repair & round ring and tie in ground wire south of 720 & D. Kelly & NW & 2-4-16/R.Lee \\
\hline 19. & Replace & wire in perimeter lighting in TREAT & D. Kelly & NW & 2-17-16/R. Lee \\
\hline 20. & Replace & fence post in TREAT south leg & D. Kelly & NW & 2-4-16/R.Lee \\
\hline 21. & Finish o & onduit in 720 & D. Kelly & NW & 3-7-16/K. Cathey \\
\hline 22. & Pull fibe & and coax into $720,721 \& 724$ & D. Kelly & NW & 3-7-16 / K. Cathey \\
\hline
\end{tabular}

Page 1 of 8 


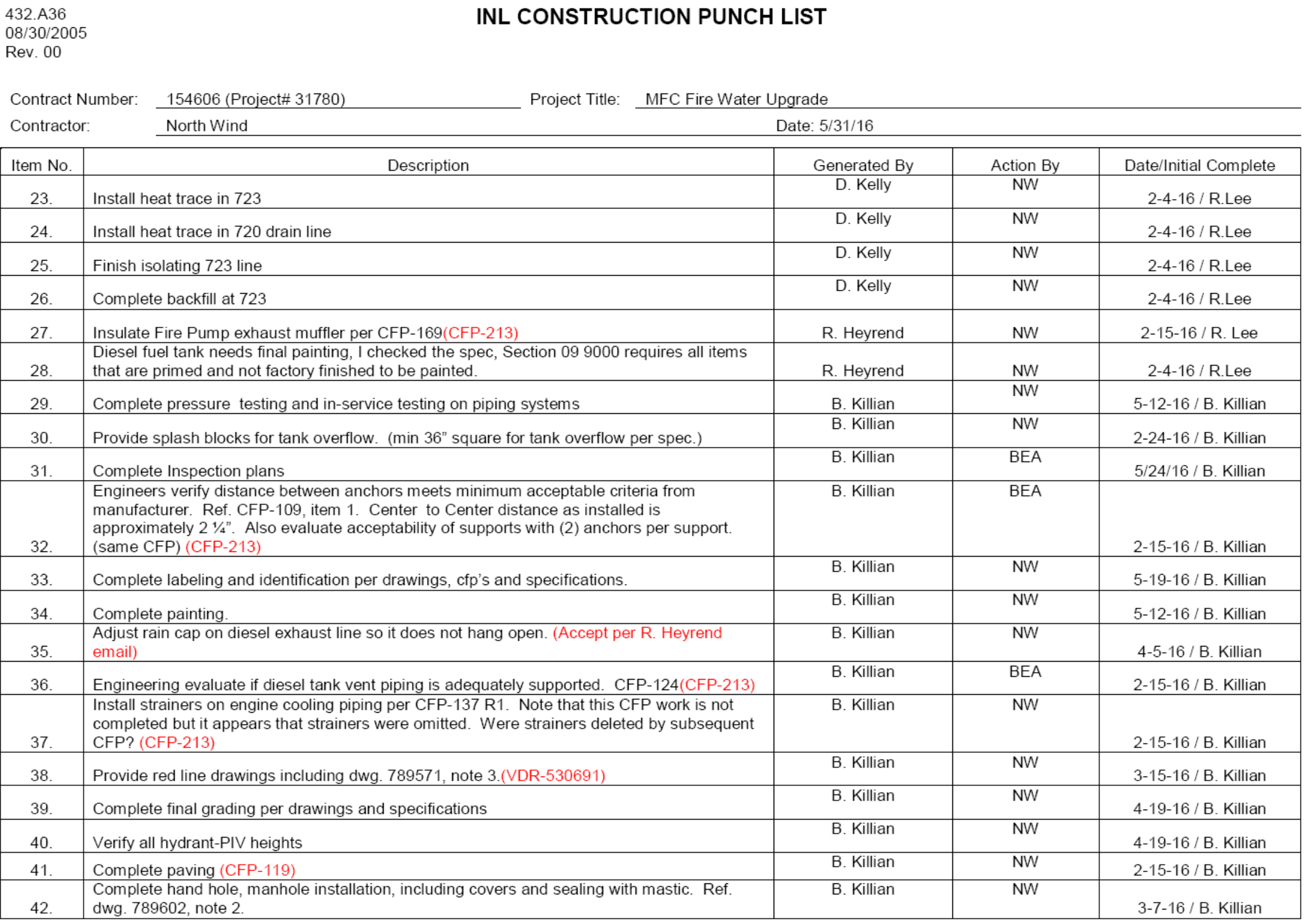

Page 2 of 8 


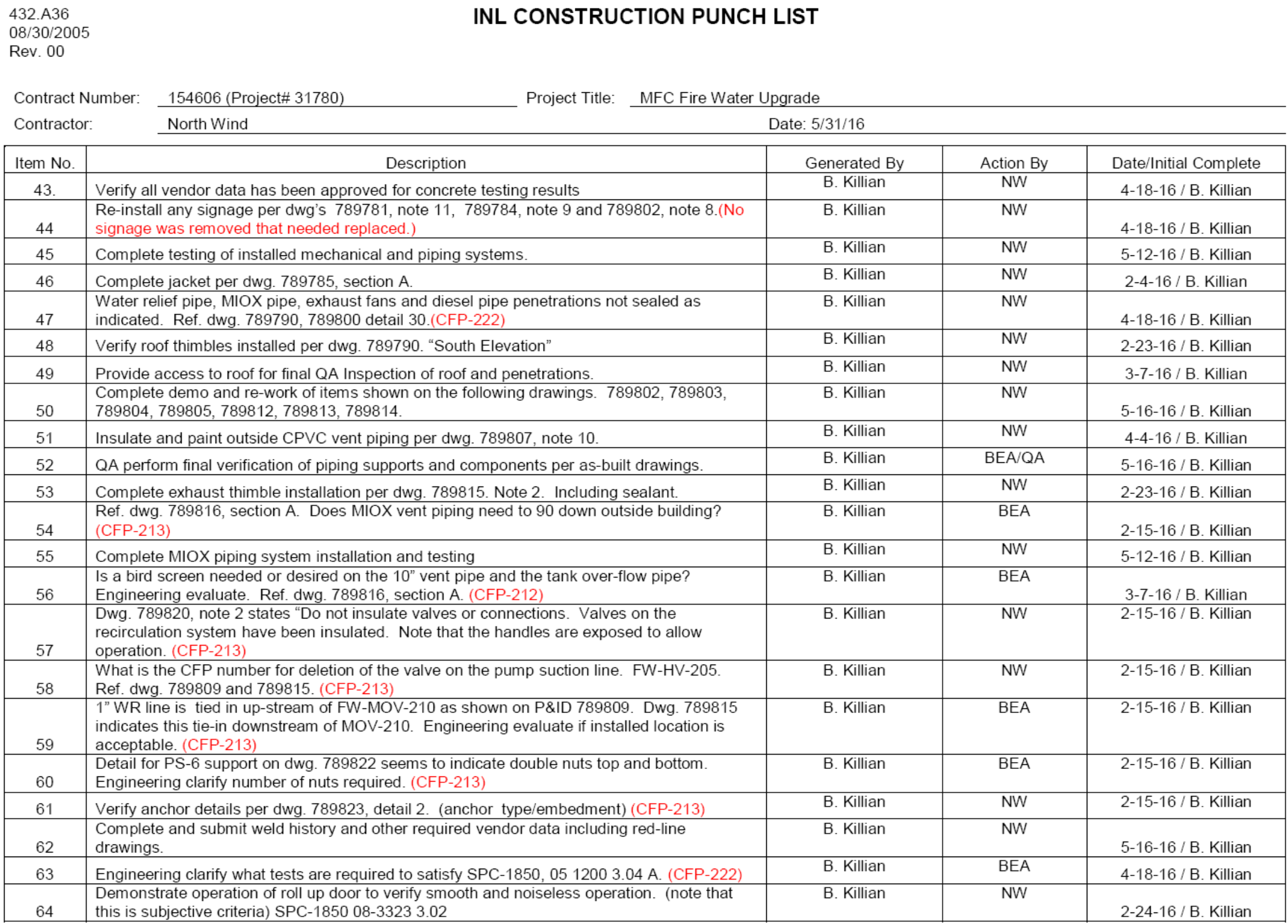

Page 3 of 8 
Rev. 00

Date: $5 / 31 / 16$

\begin{tabular}{|c|c|c|c|c|}
\hline Item No. & Description & Generated By & Action By & Date/Initial Complete \\
\hline 65 & $\begin{array}{l}\text { AHJ and Engineering review test reports to verify adequate flushing flows and duration. SPC } \\
18502111013.02 \text { (R. Heyrend email) }\end{array}$ & B. Killian & BEA & 5-3-16 / B. Killian \\
\hline 66 & Perform valve function test with QA witness per SPC-1850, $2111013.02 \mathrm{C}$. & B. Killian & NW & 2-4-16 / B. Killian \\
\hline 67 & $\begin{array}{l}\text { QA review approved wet pipe Firewater as-built drawings to verify installed configuration } \\
\text { matches drawings. }\end{array}$ & B. Killian & BEA & 4-16-16 / B. Killian \\
\hline 68 & Flushing and flow tests per SPC-1850, 21 1301, 3.02 must be completed. & B. Killian & NW & 4-4-16 / B. Killian \\
\hline 69 & Complete testing and flushing per SPC-1850, 2130003.02 . & B. Killian & NW & 5-12-16/B. Killian \\
\hline 70 & $\begin{array}{l}\text { SPC- } 1850,221005,2.03 \text { requires all diesel fuel and vent systems to be A53 galvanized } \\
\text { pipe. S/C has installed plain black pipe and fittings. If b lack is approved for use, is painting } \\
\text { of exposed exterior black pipe and fittings required? (CFP-213) }\end{array}$ & B. Killian & NW & 2-15-16 / B. Killian \\
\hline 71 & Bacterial test of systems per SPC-1850, 22 1005, 3.03 D.2. & B. Killian & BEA & 5-12-16 / B. Killian \\
\hline 72 & $\begin{array}{l}\text { Verify Vendor data approved for equipment under SPC-1850, } 22 \text { 3000. (Confirmed per VDS } \\
\& \text { Z. Mickelsen Email) }\end{array}$ & B. Killian & NW & 3-15-16 / B. Killian \\
\hline 73 & Complete Test and Balance per SPC-1850, 230593 & B. Killian & NW & 2-23-16 / B. Killian \\
\hline 74 & Weld maps for tank installation and other data required per SPC-1850, $331613,1.04$. & B. Killian & NW & 4-29-16 / B. Killian \\
\hline 75 & Verify hydrant lockable per SPC-1837, $331100,2.05$ B.(acceptable per R. Heyrend email) & B. Killian & NW & 3-16-16 / B. Killian \\
\hline 76 & Provide operating wrenches per SPC-1837, 33 1100, 2.07. & B. Killian & NW & 4-29-16 / B. Killian \\
\hline 77 & $\begin{array}{l}\text { Do we have a CFP for SPC-1837, } 33 \text { 1100, } 3.02 \text { C.? Drawings show numerous flanges } \\
\text { underground. (CFP-213) }\end{array}$ & B. Killian & NW & 2-15-16 / B. Killian \\
\hline 78 & Complete sealing on tanks around the ladders. & B. Killian & NW & 3-7-16 / B. Killian \\
\hline 79 & Complete flashing and sealing of roof penetrations on old tank. & B. Killian & NW & 3-7-16 / B. Killian \\
\hline 80 & $\begin{array}{l}\text { Complete crimping of joints, especially behind ladder on old tank. Also need to determine } \\
\text { adequate fastening for insulation panel behind this ladder. }\end{array}$ & B. Killian & NW & 2-23-16 / B. Killian \\
\hline 81 & $\begin{array}{l}\text { Complete flashing/sealing and panel attachment at tank to building interfaces. Ensure } \\
\text { panels are securely fastened at this interface. }\end{array}$ & B. Killian & NW & 3-7-16 / B. Killian \\
\hline 82 & $\begin{array}{l}\text { QA will need access by manlift once the contractor believes the building to roof interfaces are } \\
\text { flashed and sealed to allow for final Inspection. ( Acceptable per D. Covert email) }\end{array}$ & B. Killian & NW & 3-7-16 / B. Killian \\
\hline 83 & $\begin{array}{l}\text { Engineering provide CFP for drain line installed from Fire Pump Controller sensing line to } \\
\text { waste drain. This drain was temporarily installed per verbal direction form facility supervisor. } \\
\text { Indic ate materials to be used, testing requirements and support requirements. (CFP-213) }\end{array}$ & B. Killian & BEA & 2-15-16 / B. Killian \\
\hline 84 & $\begin{array}{l}\text { Engineering determine if valves and fittings for the Fire Pump controller sensing line need to } \\
\text { be "Lead Free". }\end{array}$ & B. Killian & BEA & 2-4-16 / B. Killian \\
\hline 85 & $\begin{array}{l}\text { Engineering determine if "dampened" gauges need to be installed at the fire pump inlet and } \\
\text { outlet. Gauges currently installed may fail due to erratic needle deflection during pump } \\
\text { operation. (CFP-213) }\end{array}$ & B. Killian & BEA & 2-15-16 / B. Killian \\
\hline
\end{tabular}

Page 4 of 8 


\section{INL CONSTRUCTION PUNCH LIST}

Rev. 00

Contract Number: 154606 (Project\# 31780) Project Title: MFC Fire Water Upgrade

Contractor: North Wind

\begin{tabular}{|c|c|c|c|c|}
\hline Item No. & Description & Generated By & Action By & Date/Initial Complete \\
\hline 86 & Seal conduit penetration in North wall of new pump house. (CFP-222) & B. Killian & NW & 4-18-16 / B. Killian \\
\hline 87 & Complete installation of fueling platform concrete anchors. & B. Killian & NW & 2-23-16 / B. Killian \\
\hline 88 & $\begin{array}{l}\text { Engineering evaluate thread engagement of concrete anchor nuts and nut type on floor } \\
\text { support installed per CFP-145 R-1. Some nuts do not have complete thread } \\
\text { engagement(CFP-213) }\end{array}$ & B. Killian & BEA & 2-15-16 / B. Killian \\
\hline 89 & $\begin{array}{l}\text { Verify work complete for CFP numbers above 160. (CFP-169 Accepted per Z. Mickelsen } \\
\text { email) }\end{array}$ & B. Killian & NW & 5-12-16 / B. Killian \\
\hline 90 & $\begin{array}{l}\text { List of CFP's (number } 160 \text { and lower) for which work is not completed: } \\
39,74,82,88,114,116,137 \mathrm{R}-1,147 \mathrm{R}-1 \text {, and } 160\end{array}$ & B. Killian & NW & 5-12-16 / B. Killian \\
\hline 91 & Chemical Inventory - Final Report - VDS-3 Schedule\# 484738 & R. Lee & NW & 5-31-16/R. Lee \\
\hline 92 & Summary of Work - As-Built Redlines - VDS-4 Schedule\# 484738 & R. Lee & NW & 5-17-16/R. Lee \\
\hline 93 & $\begin{array}{l}\text { Affirmative Procurement Requirements - Recovered Materials Report - VDS-5 Schedule\# } \\
484738\end{array}$ & R. Lee & NW & 5-11-16/R. Lee \\
\hline 94 & Altitude Control Valves - VDS-32 Schedule\# 484738 & R. Lee & NW & 5-11-16/R. Lee \\
\hline 95 & Hydrostatic Test Report - VDS-35 Schedule\# 484738 & R. Lee & NW & 2-4-16/R.Lee \\
\hline 96 & Valve Functional Test Rpt. - VDS-37 Schedule\# 484738 & R. Lee & NW & 3-15-16 / R.Lee \\
\hline 97 & Wet-Pipe Fire Suppression - C of C - VDS-44 Schedule\# 484738 & R. Lee & NW & 3-7-16/ R. Lee \\
\hline 98 & Wet-Pipe Fire Suppression - Electronic As-built Drawings - VDS-46 Schedule\# 484738 & R. Lee & NW & 2-4-16/ R.Lee \\
\hline 99 & Catalog Data - VDS-47 Schedule\# 484738 & R. Lee & NW & 5-11-16/R. Lee \\
\hline 100 & Pressure Test Rpt. - VDS-59 Schedule\# 484738 & R. Lee & NW & 2-13-16/R. Lee \\
\hline 101 & Weld Records - VDS-62 Schedule\# 484738 & R. Lee & NW & 2-17-16/R. Lee \\
\hline 102 & TAB - TAB Report - VDS-73 Schedule\# 484738 & R. Lee & NW & 2-24-16/R. Lee \\
\hline 103 & I\&C Devices for HVAC/PLUMBING - Product Data - VDS-75 Schedule\# 484738 & R. Lee & NW & 5-17-16/R. Lee \\
\hline 104 & I\&C Devices for HVAC/PLUMGING - Shop Drawings - VDS-76 Schedule\# 484738 & R. Lee & NW & 5-17-16/R. Lee \\
\hline 105 & I\&C Devices for HVAC/PLUMBING - Installation Instructions - VDS-77 Schedule\# 484738 & R. Lee & NW & 5-17-16/R. Lee \\
\hline 106 & $\begin{array}{l}\text { I\&C Devices for HVAC/PLUMPING - Electronic As-Built Autocad Drawings - VDS-78 } \\
\text { Schedule\# } 484738\end{array}$ & R. Lee & NW & 5-17-16/R. Lee \\
\hline 107 & I\&C Devices for HVAC/PLUMBING- O\&M - VDS-79 Schedule\# 484738 & R. Lee & NW & 5-17-16/R. Lee \\
\hline 108 & I\&C Devices for HVAC/PLUMBING - Warranty - VDS-80 Schedule\# 484738 & R. Lee & NW & $5-17-16 /$ R. Lee \\
\hline 109 & I \& C SUBMITTAL PACKAGE 3 - VDS-83 Schedule\# 484738 & R. Lee & NW & 5-31-16/R. Lee \\
\hline 110 & I \& C SUBMITTAL PACKAGE 4- VDS-84 Schedule\# 484738 & R. Lee & NW & 5-31-16/R. Lee \\
\hline
\end{tabular}

Page 5 of 8 
Contract Number: 154606 (Project\# 31780) Project Title: MFC Fire Water Upgrade

\begin{tabular}{ll|l} 
Contractor: & North Wind & Date: $5 / 31 / 16$
\end{tabular}

\begin{tabular}{|c|c|c|c|c|}
\hline Item No. & Description & Generated By & Action By & Date/Initial Complete \\
\hline 111 & I \& C SUBMITTAL PACKAGE 5 - VDS-85 Schedule\# 484738 & R. Lee & NW & 5-31-16/R. Lee \\
\hline 112 & I \& C SUBMITTAL PACKAGE 6 - VDS-86 Schedule\# 484738 & R. Lee & NW & 5-24-16 / R. Lee \\
\hline 113 & I \& C SUBMITTAL PACKAGE 7 - VDS-87 Schedule\# 484738 & R. Lee & NW & 5-24-16 / R. Lee \\
\hline 114 & I \& C SUBMITTAL PACKAGE 8 - VDS-88 Schedule\# 484738 & R. Lee & NW & 5-31-16/R. Lee \\
\hline 115 & I \& C SUBMITTAL PACKAGE 9 - VDS-89 Schedule\# 484738 & R. Lee & NW & 5-31-16/R. Lee \\
\hline 116 & Cable, Wire \& Connectors - Cable Pull Sheets - VDS-90 Schedule\# 484738 & R. Lee & NW & 2-13-16/R. Lee \\
\hline 117 & $\begin{array}{l}\text { Cable, Wire \& Connectors - Cable Pulling Procedure for SR Cable - VDS-91 Schedule\# } \\
484738\end{array}$ & R. Lee & NW & 2-13-16/ R. Lee \\
\hline 118 & Cable, Wire \& Connectors - Pull-by Schedule - VDS-92 Schedule\# 484738 & R. Lee & NW & 2-4-16/R.Lee \\
\hline 119 & Cable, Wire \& Connectors - Megger Test Results - VDS-94 Schedule\# 484738 & R. Lee & NW & 2-4-16/R.Lee \\
\hline 120 & Cable, Wire \& Connectors - Continuity Test Results - VDS-96 Schedule\# 484738 & R. Lee & NW & 2-4-16/R.Lee \\
\hline 121 & Grounding - Test Results - VDS-99 Schedule\# 484738 & R. Lee & NW & 3-15-16/R.Lee \\
\hline 122 & Low-Voltage Transformers -Warranty- VDS-102 Schedule\# 484738 & R. Lee & NW & 2-17-16/R. Lee \\
\hline 123 & Panelboards and Circuit Breakers - O\&M- VDS-106 Schedule\# 484738 & R. Lee & NW & 2-4-16/R.Lee \\
\hline 124 & Wiring Devices - Product Data- VDS-107 Schedule\# 484738 & R. Lee & NW & 2-4-16/R.Lee \\
\hline 125 & Wiring Devices - Installation Instructions- VDS-108 Schedule\# 484738 & R. Lee & NW & 2-13-16/R. Lee \\
\hline 126 & Wiring Devices - O\&M- VDS-109 Schedule\# 484738 & R. Lee & NW & 2-4-16/ R.Lee \\
\hline 127 & Interior Lighting - Warranty- VDS-112 Schedule\# 484738 & R. Lee & NW & 2-4-16/R.Lee \\
\hline 128 & Interior Lighting - O\&M- VDS-113 Schedule\# 484738 & R. Lee & NW & 2-4-16/R.Lee \\
\hline 129 & Fire Detection and Alarm - Inspection and Test Report- VDS-119 Schedule\# 484738 & R. Lee & NW & 2-13-16/R. Lee \\
\hline 130 & Fire Detection and Alarm - O\&M- VDS-120 Schedule\# 484738 & R. Lee & NW & 2-13-16/R. Lee \\
\hline 131 & $\begin{array}{l}\text { Fire Detection and Alarm - Electronic Autocad As-built Drawings- VDS-121 Schedule\# } \\
484738\end{array}$ & R. Lee & NW & 3-15-16/ R.Lee \\
\hline 132 & Fire Detection and Alarm - Closeout Documents- VDS-122 Schedule\# 484738 & R. Lee & NW & 3-22-16/ R. Lee \\
\hline 133 & Fire Detection and Alarm - Maintenance Materials - VDS-123 Schedule\# 484738 & R. Lee & NW & 2-13-16/R. Lee \\
\hline 134 & Above Ground Water Tanks - Disinfection Test Report - VDS-130 Schedule\# 484738 & R. Lee & NW & 5-12-16/R. Lee \\
\hline 135 & Above Ground Water Tanks - Testing Agency Qualifications - VDS-131 Schedule\# 484738 & R. Lee & NW & 5-12-16 / R. Lee \\
\hline 136 & $\begin{array}{l}\text { Above Ground Water Tanks - Painting and Coating Product Data - VDS-132 Schedule\# } \\
484738\end{array}$ & R. Lee & NW & 5-11-16/R. Lee \\
\hline
\end{tabular}

Page 6 of 8 


\begin{tabular}{|c|c|c|c|c|}
\hline Item No. & Description & Generated By & Action By & Date/Initial Complete \\
\hline 137 & Fiber Optic Cable - Certifications - VDS-134 Schedule\# 484738 & R. Lee & NW & 2-4-16/ R.Lee \\
\hline 138 & Fiber Optic Cable - Test Procedure - VDS-135 Schedule\# 484738 & R. Lee & NW & 3-7-16/ R. Lee \\
\hline 140 & As-Built Construction Documents - VDS-1 Schedule\# 484881 & R. Lee & NW & 5-16-16/R. Lee \\
\hline 141 & Affirmative Procurement Requirements - VDS-2 Schedule\# 484881 & R. Lee & NW & 5-12-16/R. Lee \\
\hline 142 & As-built Survey Data - VDS-3 Schedule\# 484881 & R. Lee & NW & 5-16-16/R. Lee \\
\hline 144 & Recycled Materials Data - VDS-7 Schedule\# 484881 & R. Lee & NW & 5-17-16/R. Lee \\
\hline 145 & Product Data - VDS-14 Schedule\# 484881 & R. Lee & NW & 5-17-16/R. Lee \\
\hline 146 & Installation Instructions - VDS-15 Schedule\# 484881 & R. Lee & NW & 5-17-16/R. Lee \\
\hline 147 & Product Data - VDS-16 Schedule\# 484881 & R. Lee & NW & 5-16-16/R. Lee \\
\hline 148 & Material Safety Data Sheets (MSDS) - VDS-17 Schedule\# 484881 & R. Lee & NW & $5-12-16 /$ R. Lee \\
\hline 149 & Grounding Exothermic Welding Procedure (if used) - VDS-18 Schedule\# 484881 & R. Lee & NW & 2-4-16 / R.Lee \\
\hline 150 & Grounding Exothermic Welder Certifications (if used) - VDS-19 Schedule\# 484881 & R. Lee & NW & 2-4-16 / R.Lee \\
\hline 152 & Fiber Optic Cable Label Sample - VDS-22 Schedule\# 484881 & R. Lee & NW & 3-7-16/ R. Lee \\
\hline 153 & Fiber Optic Cable Test Procedure - VDS-23 Schedule\# 484881 & R. Lee & NW & 5-11-16/R. Lee \\
\hline 154 & Fiber Optic Cable Test Reports - After Installation - VDS-24 Schedule\# 484881 & R. Lee & NW & 5-11-16/R. Lee \\
\hline 155 & Fiber Optic Splicer Qualification Record - VDS-25 Schedule\# 484881 & R. Lee & NW & 3-7-16 / R. Lee \\
\hline 156 & Product Data - VDS-29 Schedule\# 484881 & R. Lee & NW & 5-16-16/R. Lee \\
\hline 157 & Red-lined As-Built Drawings- VDS-31 Schedule\# 484881 & R. Lee & NW & 5-17-16/ R. Lee \\
\hline 158 & Material and Test Certification - VDS-36 Schedule\# 484881 & R. Lee & NW & 2-13-16/R. Lee \\
\hline 159 & Chemical Inventory List - Final- VDS-43 Schedule\# 484881 & R. Lee & NW & 5-11-16/R. Lee \\
\hline 160 & $\begin{array}{l}\text { Finish all duct banks on print E-3 and install fiber and terminate and Test. outside of the } \\
\text { fence }\end{array}$ & K. Cathey & NW & 5-3-16 / K. Cathey \\
\hline 161 & $\begin{array}{l}\text { Fix the duct bank on back of MFC- } 724 \text { or write a cfp to except as is installed. Reference } \\
\text { CFP-35. outside of the fence }\end{array}$ & K. Cathey & NW & 2-19-16 / K. Cathey \\
\hline 162 & $\begin{array}{l}\text { On print E- } 4 \text { bond all conduits pull in fiber and cat- } 5 \text { cable. Install J-boxes. outside of the } \\
\text { fence }\end{array}$ & K. Cathey & NW & 3-7-16 / K. Cathey \\
\hline
\end{tabular}

Page 7 of 8 


\begin{tabular}{|c|c|c|c|c|}
\hline Item No. & Description & Generated By & Action By & Date/Initial Complete \\
\hline 163 & On print E-5 install fiber and test. outside of the fence & K. Cathey & NW & 5-3-16/K. Cathey \\
\hline 164 & On print E- 6 install and terminate fiber in MFC-1728. outside of the fence & K. Cathey & NW & $5-3-16 /$ K. Cathey \\
\hline 165 & $\begin{array}{l}\text { Print E-2 finish conduit, duct bank and install fiber to MFC-754 terminate and test. inside of } \\
\text { the fence }\end{array}$ & K. Cathey & NW & $5-11-16 /$ K. Cathey \\
\hline 166 & $\begin{array}{l}\text { Print E-3 Finish all wiring inside of new pump house } 1740 . \text { Then test all equipment. inside of } \\
\text { the fence }\end{array}$ & K. Cathey & NW & 2-19-16 / K. Cathey \\
\hline 167 & Print E-4 install fiber rack and install fiber terminate and test. inside of the fence & K. Cathey & NW & 2-19-16/K. Cathey \\
\hline 168 & $\begin{array}{l}\text { Print E-5 none of this work has even been started. So all of this print needs to be done. } \\
\text { inside of the fence }\end{array}$ & K. Cathey & NW & 5-11-16 / K. Cathey \\
\hline 169 & $\begin{array}{l}\text { Print E-8 Have ATS terminate all of the controls for multiple equipment and test. inside of the } \\
\text { fence }\end{array}$ & K. Cathey & NW & 5-11-16 / K. Cathey \\
\hline 170 & On prints IN-1 thru IN-7 have ATS install and test all equipment. inside of the fence & K. Cathey & NW & 3-7-16/K. Cathey \\
\hline 171 & On prints FA- 1 and 2 install all wiring and equipment then test Fire Alarm. inside of the fence & K. Cathey & NW & 2-19-16/K. Cathey \\
\hline 172 & Finish conduit run from manhole outside 720 to inside 720. & K. Cathey & NW & 3-7-16/K. Cathey \\
\hline 173 & Pull fiber inside 720 and test. & K. Cathey & NW & 5-3-16/K. Cathey \\
\hline 174 & Install fiber inside 720 above I and $\mathrm{C}$ area. & K. Cathey & NW & 3-7-16/K. Cathey \\
\hline 175 & Install ground plate behind 721 . & K. Cathey & NW & 4-14-16/K. Cathey \\
\hline 176 & Terminate and Test all fiber in $720,721,724$, Dial room. & K. Cathey & NW & 5-3-16 / K. Cathey \\
\hline 177 & Pull new conductors for lighting behind 720 . & K. Cathey & NW & 2-17-16/K. Cathey \\
\hline 178 & Finish all electrical work in HFEF and 754. & K. Cathey & NW & 5-12-16/ K. Cathey \\
\hline 179 & $\begin{array}{l}\text { Fix fuses for exhaust fans, there are } 30 \text { amp fuses on number } 12 \text { wire from fan motor to first } \\
\text { disconnect. }\end{array}$ & K. Cathey & NW & 2-24-16 / K. Cathey \\
\hline 180 & Complete all electrical work in MFC-707 & K. Cathey & NW & 5-17-16/K. Cathey \\
\hline
\end{tabular}




\section{Appendix E,}

\section{Project Risk Register}

\begin{tabular}{|c|c|c|c|c|c|c|c|}
\hline $\begin{array}{c}\text { Item } \\
\#\end{array}$ & Description & Probability & $\begin{array}{c}\text { Impact } \\
\text { (\$) }\end{array}$ & MR Account (\$) & Comments & Mitigations & $\begin{array}{c}\text { MR } \\
\text { Balance }\end{array}$ \\
\hline 1 & $\begin{array}{l}\text { Pump control } \\
\text { configurations }\end{array}$ & Medium & $\$ 45,000$ & $\$ 45,000$ & $\begin{array}{l}\text { Our current design with the } 5 \text { new } \\
\text { pumps system would be considered a } \\
\text { custom system, which also needs to } \\
\text { be interlocked with the existing pump } \\
\text { system controls. }\end{array}$ & $\begin{array}{l}\text { Incorporated the interface pump control } \\
\text { requirements into the project design documents for } \\
\text { the subcontractor to perform the pump control } \\
\text { design. }\end{array}$ & $\begin{array}{l}\$ 45,000 \\
(\mathrm{TEC})\end{array}$ \\
\hline 2 & Encountering lava rock & High & $\$ 40,000$ & $\$ 40,000$ & $\begin{array}{l}\text { Rock probing inside the fence areas at } \\
\text { MFC and TREAT was not part of the } \\
\text { planning stage of this project and we } \\
\text { could encounter approx. } 300 \text { feet of } \\
\text { additional rock excavation than } \\
\text { estimated. The associated costs are } \\
\text { prorated from the subcontractor's } \\
\text { schedule of values on this activity. }\end{array}$ & $\begin{array}{l}\text { We stated in the design documents that rock would } \\
\text { be encountered and the bids shall include this item. }\end{array}$ & $\begin{array}{l}\$ 40,000 \\
(\mathrm{TEC})\end{array}$ \\
\hline 3 & $\begin{array}{l}\text { Encountering hazardous } \\
\text { waste oil at MFC-755 }\end{array}$ & Medium & $\$ 125,000$ & $\$ 125,000$ & $\begin{array}{l}\text { DD \&D has been completed and we } \\
\text { did not encounter any spills in the } \\
\text { area of the old waste oil tanks and } \\
\text { pump house. }\end{array}$ & & $\begin{array}{l}-\$ 125,000 \\
(\mathrm{TEC})\end{array}$ \\
\hline 4 & $\begin{array}{l}\text { Encountering radiological } \\
\text { contamination }\end{array}$ & Medium & $\$ 100,000$ & $\$ 100,000$ & $\begin{array}{l}\text { It's unknown at this time if there's any } \\
\text { contamination within the CERCLA } \\
\text { areas. However, the location of the } \\
\text { existing and new fire water lines will } \\
\text { be located in areas where possible } \\
\text { contamination could be encountered. }\end{array}$ & $\begin{array}{l}\text { Expanded the limits of the radiological and } \\
\text { CERCLA sites in the design documents to allow } \\
\text { for spread and leaching conditions. We also } \\
\text { evaluated existing sampling results and we will be } \\
\text { performing additional sampling during the } \\
\text { excavation process. }\end{array}$ & $\begin{array}{l}\$ 100,000 \\
(\mathrm{TEC})\end{array}$ \\
\hline 5 & $\begin{array}{l}\text { Encountering deteriorated } \\
\text { water lines, which requires } \\
\text { connecting the old/new } \\
\text { lines together }\end{array}$ & Medium & $\$ 30,000$ & $\$ 30,000$ & $\begin{array}{l}\text { The condition of the old lines that are } \\
\text { to be connected to the new lines is not } \\
\text { known at this time. Facilities have } \\
\text { had problems with the existing lines } \\
\text { leaking in the past. We are assuming } \\
\text { that we will encounter approx. } 200 \\
\text { feet of old lines that will require } \\
\text { replacement. The associated costs are } \\
\text { prorated from the subcontractor's } \\
\text { schedule of values on this activity. }\end{array}$ & $\begin{array}{l}\text { Utilized MFC plant SMEs input on the existing } \\
\text { mains that will require new tie-in points. During } \\
\text { maintenance and repair activities over the past } 10 \\
\text { years, we have determined that the existing mains } \\
\text { are in good condition. }\end{array}$ & $\begin{array}{l}\$ 30,000 \\
(\mathrm{TEC})\end{array}$ \\
\hline
\end{tabular}




\begin{tabular}{|c|c|c|c|c|c|c|c|}
\hline $\begin{array}{c}\text { Item } \\
\#\end{array}$ & Description & Probability & $\begin{array}{l}\text { Impact } \\
\text { (\$) }\end{array}$ & MR Account (\$) & Comments & Mitigations & $\begin{array}{c}\text { MR } \\
\text { Balance }\end{array}$ \\
\hline 6 & $\begin{array}{l}\text { Encountering underground } \\
\text { interferences }\end{array}$ & High & $\$ 50,000$ & $\$ 50,000$ & $\begin{array}{l}\text { The subsurface investigation will } \\
\text { identify some of the interferences. } \\
\text { However, with the congested areas it } \\
\text { will be difficult if not impossible to } \\
\text { identify all of the underground } \\
\text { utilities and we will have to assume } \\
\text { that only } 75 \% \text { of the utilities will be } \\
\text { detected by the subsurface } \\
\text { investigation process. }\end{array}$ & $\begin{array}{l}\text { Conducted subsurface evaluations during the } \\
\text { design, which include facility configuration control } \\
\text { documents. Additionally, will perform subsurface } \\
\text { evaluations prior to excavation. }\end{array}$ & $\begin{array}{l}\$ 50,000 \\
(\mathrm{TEC})\end{array}$ \\
\hline 7 & $\begin{array}{l}\text { Encountering hazardous } \\
\text { materials (lead paint, } \\
\text { heavy metals) on the } \\
60,000 \text {, and } 100,000 \\
\text { gallon fuel tanks and } \\
200,000 \text { gallon water tank } \\
\text { during demolition. } \\
\end{array}$ & Medium & $\$ 80,000$ & $\$ 80,000$ & $\begin{array}{l}\text { Sampling has been performed and } \\
\text { determined that the materials from } \\
\text { the tanks can be mass-balanced, } \\
\text { which will meet the requirements for } \\
\text { excess materials. }\end{array}$ & & $\begin{array}{l}-\$ 80,000 \\
(\mathrm{TEC})\end{array}$ \\
\hline 8 & $\begin{array}{l}\text { Subcontract change orders } \\
\text { for design errors and } \\
\text { omissions }\end{array}$ & Medium & $\$ 378,767$ & $\$ 378,767$ & $\begin{array}{l}\text { It's assumed that the project will } \\
\text { encounter unknowns during the } \\
\text { construction time frame, which could } \\
\text { impact the project schedule. This } \\
\text { amount was reduced by } \$ 487 \mathrm{~K} \text { that } \\
\text { was put in the baseline for change } \\
\text { orders. }\end{array}$ & $\begin{array}{l}\text { BEA made allowances for added project } \\
\text { management personnel during the execution phase } \\
\text { to minimize time impacts of resolving } \\
\text { subcontractor identified field problems. }\end{array}$ & $\begin{array}{l}\$ 378,767 \\
\text { (TEC) }\end{array}$ \\
\hline 9 & $\begin{array}{l}\text { CERCLA Soil sampling } \\
\text { and possible construction } \\
\text { delay (unknown change) } \\
\text { impacts requiring } \\
\text { additional non-dedicated } \\
\text { operational support } \\
\text { personnel. } \\
\end{array}$ & Medium & $\$ 45,000$ & $\$ 45,000$ & & $\begin{array}{l}\text { Expanded the limits of the radiological and } \\
\text { CERCLA sites on design documents to allow for } \\
\text { spread and leaching conditions. Also evaluated } \\
\text { existing sample results and perform additional } \\
\text { sampling during excavation. }\end{array}$ & $\begin{array}{l}\$ 45,000 \\
(\mathrm{OPC})\end{array}$ \\
\hline & & & $\begin{array}{l}\text { Total } \\
\text { MR }\end{array}$ & $\begin{array}{r}\$ 1,315,768 \\
(\text { TEC) } \\
\\
\$ 45,000 \\
(\text { OPC }) \\
\end{array}$ & & & $\begin{array}{l}\$ 643,767 \\
(T E C) \\
\\
\$ 45,000 \\
(\text { OPC) }\end{array}$ \\
\hline 10 & Contingency & Unknown & Unknown & 0 & $\begin{array}{l}\$ 250,000 \text { identified for unknown } \\
\text { impact(s) of event(s) outside the } \\
\text { project's control, such as an external } \\
\text { event causing shutdown of MFC and } \\
\text { stopping all construction work. }\end{array}$ & & \\
\hline
\end{tabular}




\section{Appendix F,}

\section{Lessons Learned Report}

PROJECT TITLE MFC Firewater Project

PROJECT NUMBER 31780

1. PROJECT JOURNAL - During each project team meeting discuss what strategies contributed to success as well as areas of potential improvement. Enter your conclusions in the table below (insert rows as needed).

\section{STRATEGIES AND PROCESSES THAT LED TO SUCCESS}

\begin{tabular}{|c|c|c|c|}
\hline Number & Date & $\begin{array}{c}\text { Prepared } \\
\text { By }\end{array}$ & Description \\
\hline 1 & $2 / 18 / 16$ & $\begin{array}{l}\text { Lessons } \\
\text { Learned } \\
\text { Meeting }\end{array}$ & 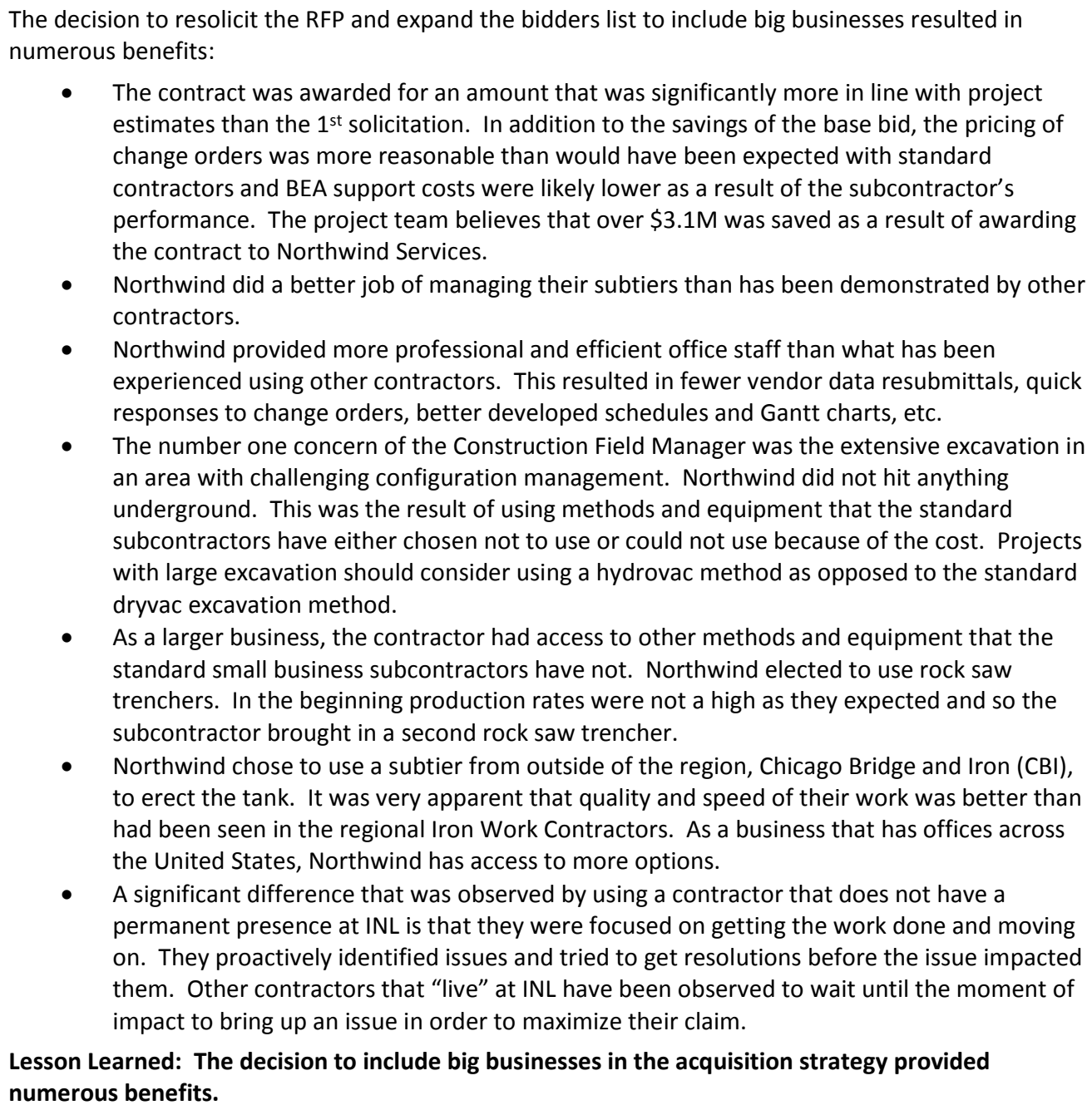 \\
\hline 2 & $2 / 18 / 16$ & $\begin{array}{l}\text { Lessons } \\
\text { Learned } \\
\text { Meeting }\end{array}$ & $\begin{array}{l}\text { The project did an excellent job of managing long lead procurements and matching the procurements } \\
\text { to the funding profile. } \\
\text { Lesson Learned: The early management of long lead procurements prevented schedule delays and } \\
\text { accommodated the funding cycles. }\end{array}$ \\
\hline
\end{tabular}




\begin{tabular}{|c|c|c|c|}
\hline 3 & $2 / 18 / 16$ & $\begin{array}{l}\text { Lessons } \\
\text { Learned } \\
\text { Meeting }\end{array}$ & $\begin{array}{l}\text { In some ways the project was broken into smaller sub projects such as the fuel oil tank demolition, } \\
\text { fabrication of the new tank, procurement of the } 14 \text { " HDPE piping, etc. It was beneficial to break up } \\
\text { some of the work into the smaller components and complete them early on before the significant } \\
\text { effort ensued. } \\
\text { Lesson Learned: Executing the work in smaller sub-projects was an effective method to manage the } \\
\text { large amount of scope. }\end{array}$ \\
\hline 4 & $2 / 18 / 16$ & S Lee & $\begin{array}{l}\text { The project effectively involved key players in the conceptual design process. } \\
\text { Lesson Learned: Involvement of key players in the early stages of the project development allows } \\
\text { for more effective team integration throughout the project. }\end{array}$ \\
\hline 5 & $2 / 18 / 16$ & $\begin{array}{l}\text { Lessons } \\
\text { Learned } \\
\text { Meeting }\end{array}$ & $\begin{array}{l}\text { The team effort and collaboration of all parties was noteworthy. There was no "us" vs "them" when it } \\
\text { came to operations, construction management, project management, subcontractor, engineering, } \\
\text { ES\&H, etc. All worked well to help mitigate impacts and help make the other players successful as } \\
\text { well. Examples include: } \\
\text { - Lock Out Tag Outs were worked collaboratively } \\
\text { - The subcontractor proceeded at risk on a majority of the CFP's in order to avoid schedule } \\
\text { impacts that would have been costly to both Northwind and BEA. } \\
\text { - The subcontractors proactively identified issues and provided recommended solutions. } \\
\text { - The subcontractors (particularly L\&L Mechanical) stated on multiple occasions that we didn't } \\
\text { just hire them to perform the identified work, but we hired them to manage the work. They } \\
\text { had a mindset that they were providing both a product and a service. } \\
\text { There was considerable pressure to influence the project to manage the Northwind } \\
\text { subcontract with "an iron fist." The project did hold the contractor accountable to } \\
\text { contractual requirements but the relationship management proved to be far more } \\
\text { important than the contract management. } \\
\text { Lesson Learned: Relationship management heavily contributes to project success. }\end{array}$ \\
\hline 6 & 2/18/16 & $\begin{array}{l}\text { Lessons } \\
\text { Learned } \\
\text { Meeting }\end{array}$ & $\begin{array}{l}\text { The weekly construction meetings were effective and well attended by the key players. The CFR } \\
\text { should be commended for his role in organizing and leading this effort. } \\
\text { Lesson Learned: Effective weekly construction meetings are essential to successful execution. }\end{array}$ \\
\hline 7 & $6 / 18 / 16$ & Lyle LaBonte & $\begin{array}{l}\text { Early on in the project it was believed that the Subcontractor Requirements Manual directed the } \\
\text { subcontractor to maintain all subsurface investigation markings. Upon realization that the } \\
\text { requirement was not part of the contractual documents, Construction Management implemented the } \\
\text { lesson learned and started including a statement in all excavation permits to require the subcontractor } \\
\text { to maintain the marks. } \\
\text { Lesson Learned: Excavation permits should require the subcontractor to maintain subsurface } \\
\text { investigation markings. }\end{array}$ \\
\hline 8 & $6 / 18 / 16$ & Lyle LaBonte & $\begin{array}{l}\text { The environmental checklist failed to identify Industrial Waste Ditch C (PER-138) and thus excavation } \\
\text { tailings were placed in the ditch. This was noticed by an MFC Environmental Support person during a } \\
\text { daily facility inspection. As a result, the project was able to stop the action, make appropriate } \\
\text { notifications and remediation of the area and no violations were noted with Idaho DEQ. This } \\
\text { highlights the importance of ES\&H field observations as an important piece of the ISMS program, } \\
\text { specifically Guiding Principle } 3 \text { Competence Commensurate with Responsibilities and the Defense in } \\
\text { Depth Model. } \\
\text { Lesson Learned: Environmental Field Observations are a critical component of ISMS (specifically } \\
\text { Defense in Depth) and help to ensure project success. }\end{array}$ \\
\hline \multicolumn{4}{|c|}{ AREAS OF POTENTIAL IMPROVEMENT } \\
\hline Number & Date & $\begin{array}{c}\text { Prepared } \\
\text { By }\end{array}$ & Description \\
\hline 9 & $10 / 1 / 15$ & B Miklos & $\begin{array}{l}\text { The project should have had more regular risk management meetings. } \\
\text { Lesson Learned: Risk management meetings throughout the project stages should be scheduled up } \\
\text { front as a regularly occurring meeting. }\end{array}$ \\
\hline
\end{tabular}




\begin{tabular}{|c|c|c|c|}
\hline 10 & $10 / 1 / 15$ & S Jensen & $\begin{array}{l}\text { The project needed to have a co-located project manager and project engineer at the job site. Many } \\
\text { of the day-to-day technical questions should have been handled between the project engineer and the } \\
\text { CFR. } \\
\text { Lesson Learned: Co-location of project team members creates an environment that allows the } \\
\text { project to respond to day-to-day issues more effectively. }\end{array}$ \\
\hline 11 & $10 / 1 / 15$ & Z Mickelsen & $\begin{array}{l}\text { A lower level of detailed planning (both project planning and engineering design) needed to occur } \\
\text { where the work interfaces between the subcontractor and BEA. Particular areas include interfaces } \\
\text { and work performed by Life Safety, Information Management, and SEECS. These are common lessons } \\
\text { learned from other projects. } \\
\text { Lesson Learned: Interfaces between subcontractor and BEA (Life Safety, Information Management, } \\
\text { and SEECS) are difficult and should be mitigated through a more detailed level of planning. }\end{array}$ \\
\hline 12 & $10 / 1 / 15$ & Z Mickelsen & $\begin{array}{l}\text { Lesson Learned: Management reserve needs to be funded on IGPP projects (or held in a pool available } \\
\text { for use). ALL construction projects will use some level of management reserve as they only use } 90 \% \\
\text { designs. }\end{array}$ \\
\hline 13 & $10 / 1 / 15$ & Z Mickelsen & $\begin{array}{l}\text { Various aspects of the project plan/schedule would have benefitted from more detailed planning } \\
\text { including: finalization of construction, transition to operations plan, closeout. This was impacted } \\
\text { because of the decision to go out for resolicitation (which saved millions of dollars). } \\
\text { Lesson Learned: Scope that is impacted by influences external to that scope can benefit from more } \\
\text { rigorous planning. }\end{array}$ \\
\hline 14 & $10 / 1 / 15$ & Z Mickelsen & $\begin{array}{l}\text { The schedule and baseline included costs for change orders but did not account for the time delays } \\
\text { associated with processing change orders. Just as a project plans for a certain level of change orders } \\
\text { because there is a greater than } 50 \% \text { probability, the schedule should take that into account as well. } \\
\text { The PMB matched the construction schedule with the subcontractor's CPM schedule. The PMB should } \\
\text { have accounted for expected delays. } \\
\text { Lesson Learned: Schedule reserve should account for delays experienced not only from the issues } \\
\text { encountered but the processing of CFP's to resolve those issues. }\end{array}$ \\
\hline 15 & $10 / 1 / 15$ & Z Mickelsen & $\begin{array}{l}\text { The project EV Plan used the apportioned method to take performance on construction change } \\
\text { orders. CFP's lag the construction schedule so a direct relationship for taking performance based on } \\
\text { the contract performance is inappropriate. The result was that the project performance reflects } \\
\text { positive cost variances early in the construction phase. On most construction projects, the majority of } \\
\text { CFP's will occur toward the middle or end of the base contract scope. } \\
\text { Lesson Learned: The apportioned method is not an ideal EV method for CFP's. }\end{array}$ \\
\hline 16 & $10 / 1 / 15$ & Z Mickelsen & $\begin{array}{l}\text { The project status was called into question because a couple of months after a particular activity had } \\
\text { been reported as completed, a punch list item was being addressed. Absent of performing a partial } \\
\text { turnover on each activity in the PMB schedule, punch list items will be encountered. } \\
\text { Lesson Learned: A more defined and communicated activity dictionary could help to improve } \\
\text { understanding of activity scope and rationale for taking earned value. }\end{array}$ \\
\hline 17 & $10 / 1 / 15$ & Z Mickelsen & $\begin{array}{l}\text { Small nuances in the project schedule ended up having a tremendous effect on the interpretation of } \\
\text { the activities. The following should be considered when developing a schedule: } \\
\text { - Substantial construction complete vs construction complete } \\
\text { - Activities that occur before and after the substantial construction complete milestone such } \\
\text { as remaining work activities, punch list items, etc. } \\
\text { - Partial turnover milestones should have partial turnover activities prior to the milestone. } \\
\text { meanings can be clarified in an activity dictionary. }\end{array}$ \\
\hline 18 & $10 / 1 / 15$ & Z Mickelsen & $\begin{array}{l}\text { The project requested to hire key resources in order to mitigate some of the items identified in the } \\
\text { lessons learned but did not receive support to do so. Due to the project being insufficiently staffed, } \\
\text { resources were stretched thin. This was compounded by working a } 6 \times 10 \text { schedule. } \\
\text { Lesson Learned: Appropriate project staffing is critical to project success. }\end{array}$ \\
\hline
\end{tabular}




\begin{tabular}{|c|c|c|c|}
\hline 19 & $2 / 18 / 16$ & $\begin{array}{l}\text { Lessons } \\
\text { Learned } \\
\text { Meeting / } \\
\text { S Jensen }\end{array}$ & $\begin{array}{l}\text { In the project formulation process, the project did not fully utilize the F\&OR and the Code of Record. } \\
\text { During design reviews people tend to focus only on the output/project and ignore the inputs/driving } \\
\text { requirements. } \\
\text { Lesson Learned: Utilize the F\&OR and the Code of Record extensively during design reviews. }\end{array}$ \\
\hline 20 & $2 / 18 / 16$ & $\begin{array}{l}\text { Lessons } \\
\text { Learned } \\
\text { Meeting }\end{array}$ & $\begin{array}{l}\text { In general, projects can do a better job at identifying the IPT. The design reviewers should be defined } \\
\text { up front. A corrective action from years past resulted in a defined design review team. } \\
\text { Lesson Learned: Ensure IPT members are appropriately identified at the project conception. }\end{array}$ \\
\hline 21 & $2 / 18 / 16$ & $\begin{array}{l}\text { Lessons } \\
\text { Learned } \\
\text { Meeting }\end{array}$ & $\begin{array}{l}\text { Changing IPT members, changes in project sponsors and reorganizations, uncertain funding profiles, } \\
\text { etc. can all contribute to a lack of continuity. Things that help maintain continuity are: System } \\
\text { Description Documents, code of record, and clear and rigorous processes for transition of } \\
\text { responsibilities. } \\
\text { Lesson Learned: There are many less than optimal circumstances encountered during the project. } \\
\text { Utilize tools that help mitigate the impacts. }\end{array}$ \\
\hline 22 & $2 / 18 / 16$ & $\begin{array}{l}\text { Lessons } \\
\text { Learned } \\
\text { Meeting }\end{array}$ & $\begin{array}{l}\text { The eCR system is cumbersome, inefficient, and sometimes bypassed with emails, etc. When design } \\
\text { review comments are provided via email, some comments can be overlooked and does not give the } \\
\text { approving engineering manager the ability to evaluate the questions asked. } \\
\text { Lesson Learned: Design reviewers need to utilize the eCR system regardless of the ease of use. }\end{array}$ \\
\hline 23 & $2 / 18 / 16$ & S Jensen & $\begin{array}{l}\text { The role of project engineer is not consistently employed in every project. } \\
\text { Lesson Learned: Ensure there are clear roles and responsibilities agreed to between work and home } \\
\text { organizations. }\end{array}$ \\
\hline 24 & $2 / 18 / 16$ & B Miklos & $\begin{array}{l}\text { The project could have benefited from better definition of the roles and responsibilities in the project } \\
\text { initiation documents. } \\
\text { Lesson Learned: Ensure there are clear roles and responsibilities agreed to between work and home } \\
\text { organizations. }\end{array}$ \\
\hline 25 & $2 / 18 / 16$ & $\begin{array}{l}\text { Lessons } \\
\text { Learned } \\
\text { Meeting }\end{array}$ & $\begin{array}{l}\text { In order to mitigate risk and protect the tank from rust during the period of delivery and fabrication, } \\
\text { the project had the tank primed. The primer was ineffective in providing adequate protection and the } \\
\text { tank ended up having to be sanded and re-primed. } \\
\text { Lesson Learned: Tank construction designs should plan for sanding and priming work to be } \\
\text { performed after the tank is erected. }\end{array}$ \\
\hline 26 & $2 / 18 / 16$ & $\begin{array}{l}\text { Lessons } \\
\text { Learned } \\
\text { Meeting }\end{array}$ & $\begin{array}{l}\text { Numerous CFP's were issued related to either design omissions or the absence of operational } \\
\text { requirements in the F\&OR. There is a void that occurs during the F\&OR development because it is } \\
\text { hard to conceptualize what will be designed. The following can help: } \\
\text { - During the F\&OR development, think about what the acceptance testing would look like. } \\
\text { - Physical observation of operators and processes, review of current Operating Instructions, } \\
\text { etc. may help identify needed information. } \\
\text { Lesson Leaned: Utilize strategies such as defining acceptance testing during the F\&OR development } \\
\text { process. }\end{array}$ \\
\hline 27 & $2 / 18 / 16$ & $\begin{array}{l}\text { Lessons } \\
\text { Learned } \\
\text { Meeting }\end{array}$ & $\begin{array}{l}\text { Funding uncertainty and the continual stop-go effect of indirect funding processes contributed to less } \\
\text { than optimal design processes (on and off again, varying team members, etc.). A way to mitigate the } \\
\text { effects would be to come up with a funding mechanism that would allow indirect funding to be carried } \\
\text { over. Options include actual balance sheet entries or recognition of the commitment in the next fiscal } \\
\text { year. } \\
\text { Funding mechanics for construction projects need to recognize the issues arise the make schedules } \\
\text { (and associated costs) ebb and flow throughout the project. The project has the responsibility to } \\
\text { mitigate impacts but it is not uncommon or improper for individual work activities to shift slightly. For } \\
\text { example, there was a } 2 \text { week schedule difference between the schedule profile developed in the } \\
\text { spring of FY15 and actual schedule progress as of September } 30,2015 \text {. The indirect funding process } \\
\text { created a scenario that would not allow the project to get ahead of schedule because it would run out } \\
\text { of funds and have to shut down, but the } 2 \text { week schedule difference shifted } \$ 600 \mathrm{~K} \text { of costs from FY15 } \\
\text { to FY16. The lab perception is that the } \$ 600 \mathrm{~K} \text { cost shift is an overrun in FY16 when in reality the } \\
\text { project is projecting to finish ahead of schedule, with a positive cost variance, and significantly lower }\end{array}$ \\
\hline
\end{tabular}




\begin{tabular}{|l|l|l|l}
\hline & & & $\begin{array}{l}\text { than the project budget base. The Lab indirect funding process relies on a project to have a 1.0 SPI } \\
\text { and CPI at fiscal year-end. This in unrealistic and cost prohibitive expectation that will result in } \\
\text { disappointment and perceived failure almost every time. } \\
\text { Lesson Learned: Indirect funding processes create life cycle project inefficiencies which are } \\
\text { avoidable through balance sheet entries. }\end{array}$ \\
\hline 28 & $3 / 7 / 16$ & Various & $\begin{array}{l}\text { The approved design separated the requirements associated with potable water systems from } \\
\text { requirements of firewater systems which resulted in the firewater pump containing internal } \\
\text { components that were not lead free as required by the potable water standards. The project } \\
\text { ultimately decided to replace the components with lead free to ensure safe drinking water. However, } \\
\text { these were custom made components and industry practices, products, and industry accepted design } \\
\text { specifications all contradict the replacement of the components. } \\
\text { Lessons learned: Regulations are often created in "stove-pipes" rather than holistically and can } \\
\text { contradict each other. Future designs should evaluate whether regulations and even specification } \\
\text { sections work congruently or against each other. }\end{array}$ \\
\hline $6 / 18 / 16$ & $\begin{array}{l}\text { Gerardo } \\
\text { Islas-Rivera }\end{array}$ & $\begin{array}{l}\text { The project encountered some delays associated with being able to backfill the trenches because } \\
\text { scope that was added to the contract but was outside of the project (placing coax in the trench) was } \\
\text { delayed. } \\
\text { Lessons Learned: Upon addition of scope to a contract, the risk register should be updated to } \\
\text { adequately reflect potential risks that may affect the project and include mitigation strategies if } \\
\text { possible. }\end{array}$ \\
\hline
\end{tabular}

2. PROJECT CLOSE-OUT DISCUSSION - At the end of your project, gather all stakeholders for a Lessons-Learned meeting; focus on Lessons Learned that will help in future projects (insert rows as needed).

\section{LIST THIS PROJECT'S THREE BIGGEST SUCCESSES}

The main subcontract was awarded at a price that was more in line with project estimates by using big businesses in the acquisition strategy.

The project avoided costly delays by effectively managing long lead GFE procurements.

Many of the project's successes were rooted in effective relationship management.

\section{LIST OTHER SUCCESSES THAT THE PROJECT TEAM WOULD LIKE HIGHLIGHTED}

The project has always remained within the acceptable variance criteria and is projecting to complete ahead of schedule and with a positive schedule variance.

All work was completed safely and without reportable injury.

\section{LIST AREAS OF POTENTIAL IMPROVEMENT ALONG WITH HIGH-IMPACT IMPROVEMENT STRATEGIES}

Improvements in the F\&OR Development would reduce the number of CFP's.

Improved and routine risk management meetings would help to identify and mitigate future impacts.

Well defined, integrated, and co-located IPT enables successful project execution.

\section{OTHER COMMENTS}

N/A

PROJECT LESSONS-LEARNED DOCUMENT I SIGNATURES - I have reviewed the information contained in this Project Lessons Learned Document and agree

\begin{tabular}{|c|c|c|}
\hline Zane Mickelsen & Sane Mickelsen & $3 / 7 / 16 \& 6 / 18 / 16$ \\
\hline Project Manager (printed name) & Signature & Date \\
\hline
\end{tabular}




\section{Appendix G,}

Final Project Transfer 
INSPECTION

PROJECT TITLE: MFC Fire Water Upgrade Project

as constructed by

North Wind

(Name of Subcontractor or Direct Hire)

\section{6}

(Subcontract No.)

(Funding No.fReq. No.)

The project (or portion of the project) was found by the Project Team (signatures as shown below) to be complete in accordance with the contractual documents except for such deficiencies specifically noted below. The project (or portion of the project) is ready for testing and start-up activities.

Deficiencies (attach list if necessary):

None See attached signed off punch list.

Comments:

Includes all scope associated with the original work scope and CFP-001 through CFP-231.

\section{PROJECT TEAM APPROVAL}

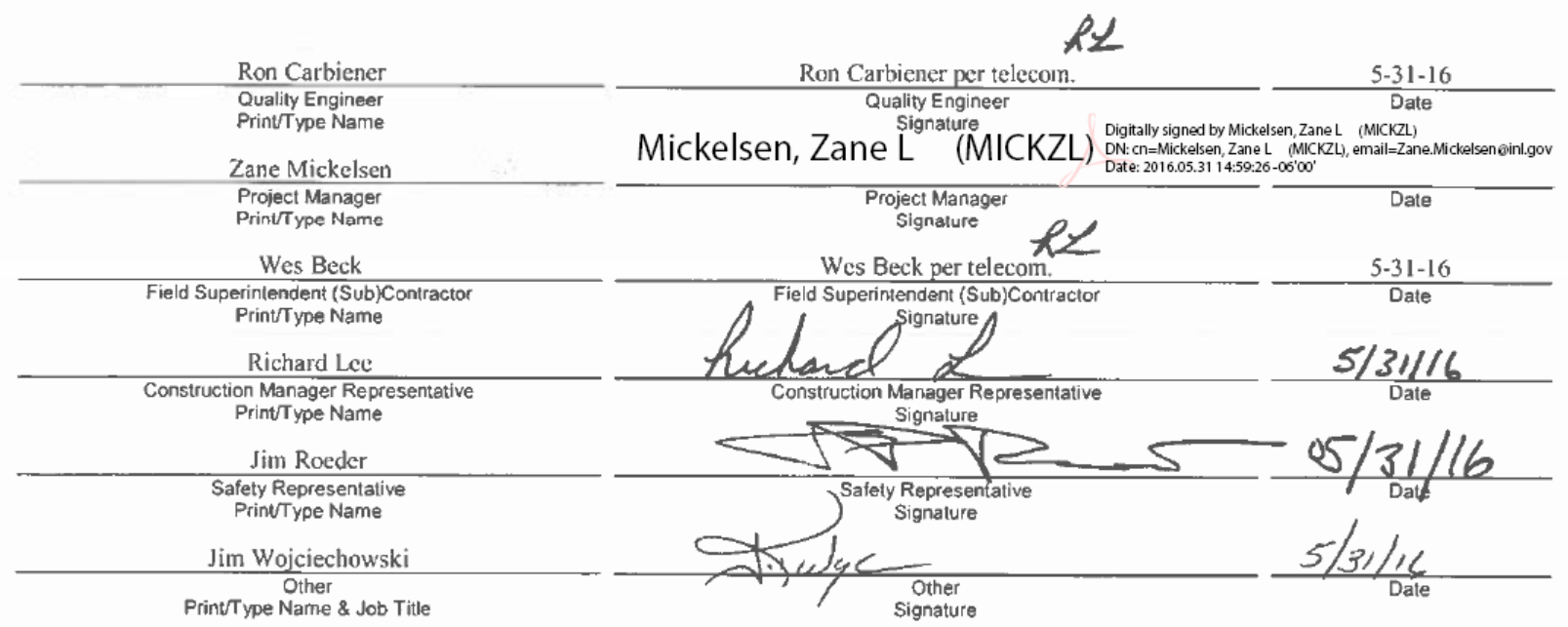




\section{PARTIAL PROJECT TRANSFER TO FACILITY MANAGER}

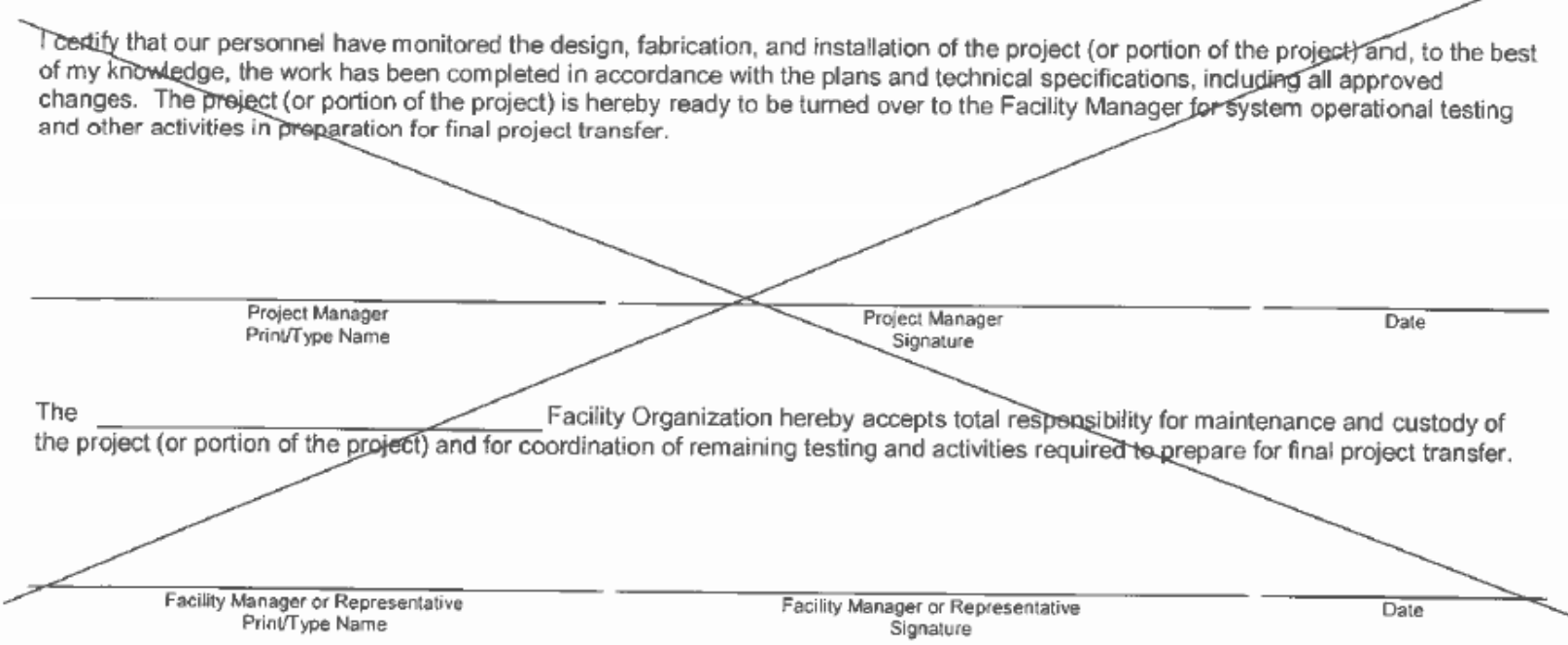

\section{INTERIM DISTRIBUTION}

Signatories, Land/Facility Operations, and Project File. For capital-funded projects include Property Accounting and Property Management.

\section{WORK COMPLETION}

\section{SUBCONTRACTOR/DIRECT HIRE:}

I certify on behalf of North Wind

subject to the penalties provided under 18 U.S.C., Section 1001, that our personnel have accomplished the contract work and, to the best of my knowledge, the work was performed or accomplished in accordance with the contractual documents, including all approved changes.

\begin{tabular}{|c|c|c|}
\hline Wes Beck & Wes Beck per telecom. & $5 / 31 / 16$ \\
\hline $\begin{array}{l}\text { Subcontractor Authorized Representative } \\
\text { Print/Type Name }\end{array}$ & $\begin{array}{l}\text { Subcontractor Authorized Representative } \\
\text { Signature }\end{array}$ & Date \\
\hline
\end{tabular}

I certify that the administration of the contract for the above named project is, to the best of my knowledge, complete to the extent required for this Project Transfer and/or close out of the contract

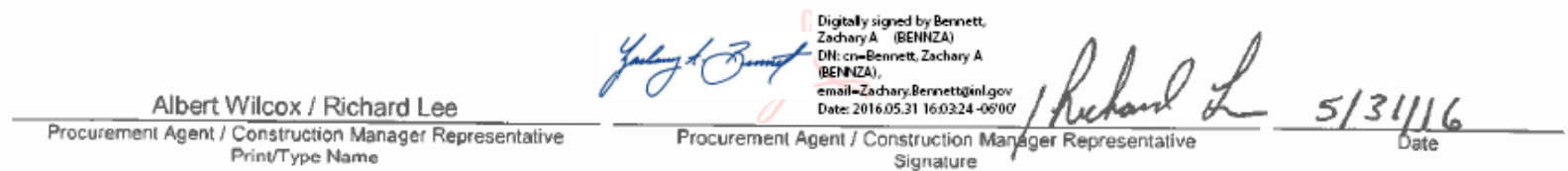


I certify completion of final testing and project review to ensure project requirements have been met in accordance with the Turnover and Acceptance Plan. The project (or portion of the project) is hereby ready to be turned over to the Facility Manager for acceptance.

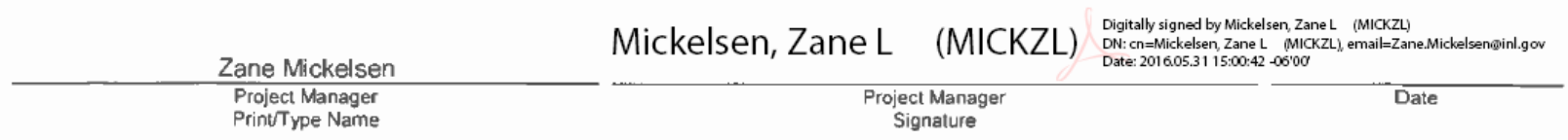

The project (or portion of the project) is hereby accepted for the Government.

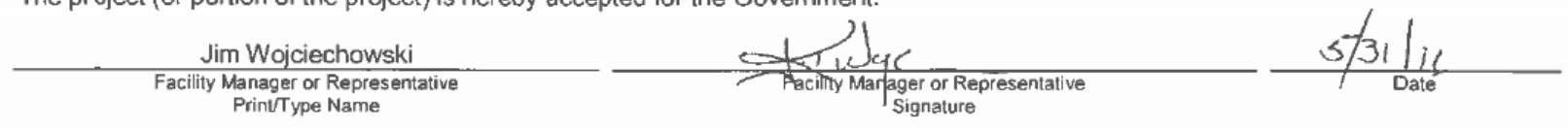

\section{FINAL DISTRIBUTION}

Signatories, plus DOE-ID Project Manager, Project File, and Land/Facility Operations. For capital-funded projects, include Property Accounting, Property Management, and Financial Construction Coordinator.

\section{INSTRUCTIONS}

In accordance with MCP-2869, "Project Turnover and Acceptance," this form documents the final inspection between the subcontractor/ direct hire and the Facility Manager, and effects partial and final transfers of the project (or portion of the project) to the Facility Manager.

\section{INSPECTION}

1. The "Inspection" section is to be used for both partial and final project transfers. In general, a partial project transfer occurs when the contract or a specific and definable portion of the project has been completed and is to be turned over to the Facility Manager for custody and maintenance. Items such as SO Testing, Life Safety System tie-ins, terminations, and final project documentation still remain to be accomplished.

2. The description needs to be detailed and clear on what is being transferred (e.g., reference drawing list, equipment list).

3. Deficiencies should only be allowed for partial transfers. If possible, include planned completion date for each deficiency.

4. Quality Engineer signs for quality significant projects, Field Engineer signs for Consumer Grade projects, or both sign for projects that are combined activities.

\section{PARTIAL PROJECT TRANSFER APPROVAL}

1. The "Partial Project Transfer to Facility Manager" section is to be filled out for partial project transfer of the project (or portion of the project) from the subcontractor/direct hire to the Facility Manager after review by the Project Turnover Review Committee demonstrates that the project (or portion of the project) is safe and ready for occupancy and SO Testing activities.

\section{WORK COMPLETION}

1. The "Work Completion" section is to be filled out to certify contract work is complete. This is to be done in conjunction with the Final Project Transfer.

\section{FINAL PROJECT TRANSFER APPROVAL}

1. The "Final Project Transfer" section is to be filled out after final testing (such as SO testing), completion of all remaining project activities, and review by the Project Turnover Review Committee demonstrate that the project (or portion of the project) is ready for acceptance by the Facility Manager/user organization.

2. Use of this form does not constitute start-up approval of the project or portion thereof. 


\section{Appendix $\mathrm{H}$,}

\section{Project Acceptance/Turnover Plan}


MFC Fire Water Replacement Project Acceptance/Turnover Plan

\title{
ACCEPTANCE/TURNOVER PLAN
}

\author{
Project: 31780
}

\section{MFC FIRE WATER REPLACEMENT PROJECT}


MFC Fire Water Replacement Project Acceptance/Turnover Plan

Effective Date: $\mathrm{XX} / \mathrm{XX} / 2014$

Page: 2 of 8

Project File No. 31780

Approved by

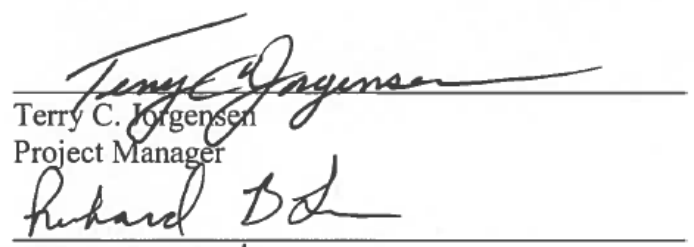

Richard B. Leeff

MFC PoormConstruction Field Representative

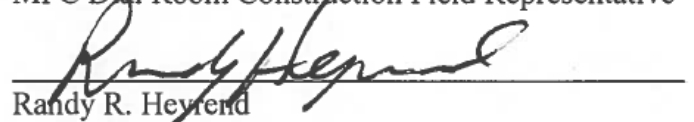

Facility Engineering

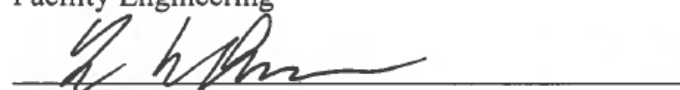

Larr Duncan

Mechanical System Engineer

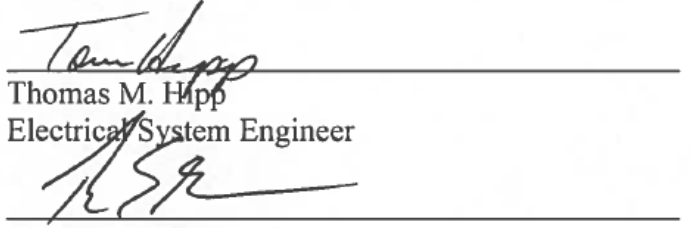

Thomas S. Bakes

Electrical System Engineer

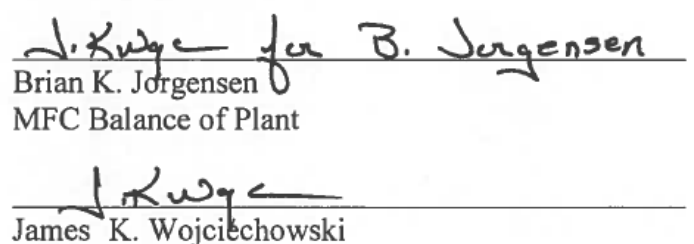

James K. Wojcikchowski

MFC Balance of Plant

Manager

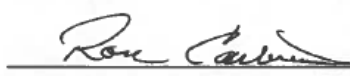

Ronald E. Carbiener

Quality Engineering

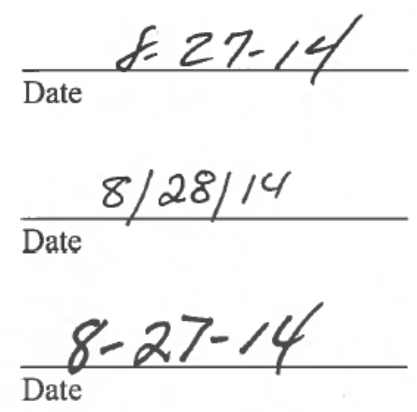

$\frac{8-27-2014}{\text { Date }}$
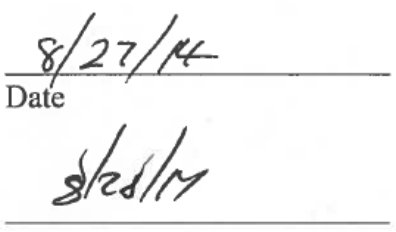

Date

$\frac{8|22| 1+}{\text { Date }}$

$8 / 29 / 14$

Date

$8 / 24 / 14$

Date 
MFC Fire Water Replacement Project Acceptance/Turnover Plan Effective Date: $\mathrm{XX} / \mathrm{XX} / 2014$

Page: 3 of 8
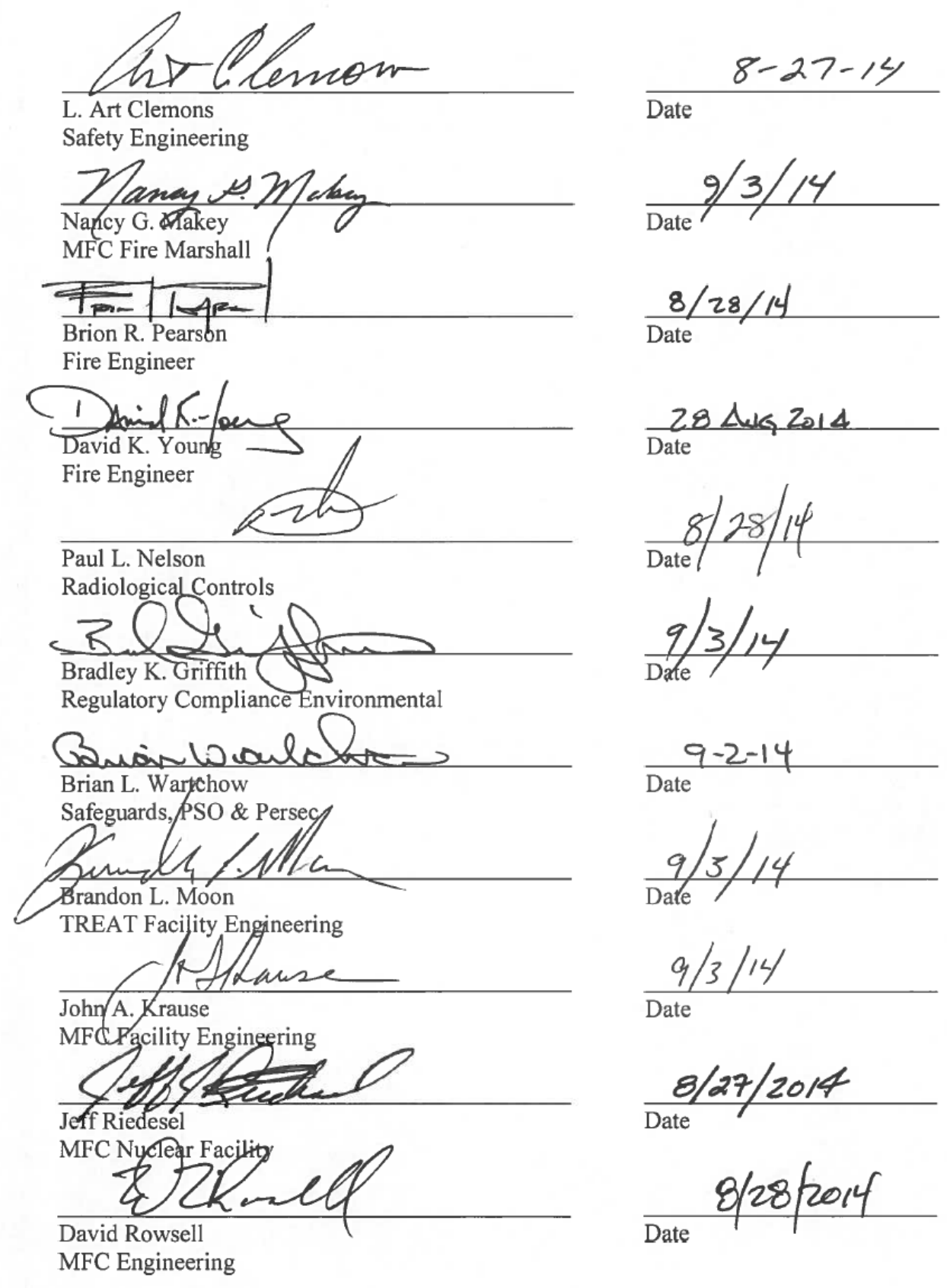

$\frac{8 / 27 / 2014}{\text { Date }}$

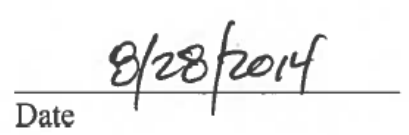


MFC Fire Water Replacement Project Acceptance/Turnover Plan

Effective Date: 09/03/2014
Page: 4 of 8

\section{Purpose:}

This document defines the process that will ensure that the requirements are met for transfer of Materials and Fuels Complex (MFC) Fire Water Replacement Project from Projects to MFC Balance of Plant (BOP). The testing and turnover process will utilize a partial transfer of the project to the end users. The acceptance and turnover process is initiated upon substantial completion of construction. The process begins with completion of partial transfer of select systems to MFC BOP once the system operability (SO) testing and review of project related documents takes place. Upon satisfactory completion of the remaining SO tests and project document, final transfer is executed. The methodology is detailed in this document and upon issuance of the final transfer, the facility (MFC BOP) will take ownership of the facility/systems operation and maintenance.

\section{Applicability:}

This document is applicable to the construction of the new MFC Fire Water Replacement (Project No. 31780) construction specifications and drawings.

The new MFC Fire Water Replacement Project will not be turned over for operation until all documentation required herein is complete and accepted by the project team.

\section{Project Team:}

The project team is comprised of individuals from several organizations. The project team will identify all documentation required for turnover of the facility for operations. The team will review all documentation for content and acceptability. Each team member is required to approve this plan and sign the approval page. The individuals, organizations, and individual functions are identified below:

Individual
Lisa A. Sehlke
Kyle S. Vogel
Terry C. Jorgensen
Linda L. Hergesheimer
Richard B. Lee
Randy R. Heyrend
Larry W. Duncan
Thomas S. Bakes
Thomas M. Hipp
James K. Wojciechowski
Brian K. Jorgensen
Ronald E. Carbiener
L. Art Clemons
John A. Krause
Brandon L. Moon
Nancy G. Makey
Brion R. Pearson
David K. Young

Individual

Terry C. Jorgensen

Linda L. Hergesheimer

Randy R. Heyrend

Larry W. Duncan

.

.

Brian K. Jorgensen

Ronald E. Carbiener

Nancy G. Makey

David K. Young

Organization
Program Manager
DOE-ID Project Manager
Project Management
Planning \& Controls
Project \& Construction
Facility Engineering
Facility Engineering
Facility Engineering
Facility Engineering
Balance of Plant
Balance of Plant
QA Program Support
ES\&H Facility Support
MFC Facility Engineer
TREAT Facility Engineer
Safety \& Health
Fire Protection
Fire Protection

Function

Program Manager

Project Manager

Project Manager

Planning \& Controls

MFC Dial Room CFR

Project Engineer

Mechanical System Engineer

Electrical System Engineer

Electrical System Engineer

MFC Facility Manager

MFC Project Integration

Quality Engineering

Safety Engineer

Facility Engineer

Facility Engineer

Fire Marshall

MFC Fire Safety

MFC Fire Safety 
MFC Fire Water Replacement Project Acceptance/Turnover Plan Effective Date: 09/03/2014

Page: 5 of 8

\author{
Paul L. Nelson \\ Bradley K. Griffith \\ John W. Gill \\ Brian L. Wartchow \\ Jeff Riedesel \\ David Rowsell
}

Radiological Controls

Regulatory Compliance

Environmental

Regulatory Compliance

Environmental

Safeguards, PSO \& Persec

Nuclear Facility

Engineering

\author{
Radiological Engineering Manager \\ Environmental Coordinator \\ Environmental \\ Security \\ Nuclear Facility \\ MFC Engineering
}

Methodology:

Readiness for turnover will be determined based on the status of project documents that identify current status of systems and equipment for the construction subcontract activities. The following documents and/or items below are available during partial and/or final project turnover.

1. Documents

a. Unreviewed safety questions (USQ) screening for impacts to MFC

b. Work order completion and close-out

c. Maintenance procedures and other related documents

d. Technical and functional requirements (T\&FRs)

e. Safety and Environmental documents (APAD Air Permit \& Environmental Checklist)

f. Training for the new fire pump system

g. Vendor data available in EDMS

h. Test reports

i. Heating, Ventilating, and Air Conditioning (HVAC) test and balance reports

j. Voice/data test reports

k. Telecommunications test reports

1. Completed inspection plans

m. Partial and final punch lists

n. Operation and maintenance manuals

2. Evidence that the performance and acceptance criteria in the T\&FRs is satisfied.

3. Test reports for required acceptance tests [Construction Component (CC) tests, System Operability (SO) tests, and system tests required by project specifications and manufacturers].

4. Essential and master as-built drawings will be identified by BOP Operations.

5. Telecommunication Operations will perform the as-built configurations of the new MFC information technology equipment modifications.

6. Construction drawings red-line as-built.

7. Partial and final turnover documentation (attached checklist for partial and final turnover).

8. Safety walk downs have been completed.

9. Security walk downs have been completed.

10. Fire department pre-incident plans.

11. MFC fire water pump system installation, commissioning, configurations, testing, and acceptance completed.

12. MFC IT system installation, commissioning, configurations, testing, and acceptance completed.

13. Configuration management completed EJN-1604 for MFC-755 D \& D Activities and EJN-1608 for the remainder of the project. 


\section{MFC Fire Water Replacement Project Acceptance/Turnover Plan}

Effective Date: 09/03/2014

Page: 6 of 8

Partial Transfer

- Construction of the new MFC Fire Water Replacement Project, which includes a 400,000 gallon tank, pumps, new fire water piping, and all associated systems.

The following readiness checklist will document readiness for partial project transfer when completed.

\begin{tabular}{|c|c|c|c|c|}
\hline \multirow{2}{*}{\multicolumn{2}{|c|}{ Deliverable or Activity }} & \multicolumn{3}{|c|}{ Completed } \\
\hline & & Yes & No & NA \\
\hline 1. & $\begin{array}{l}\text { Final inspection walkthrough. } \\
\text { Note: The walkthrough ensures that all physical work required by } \\
\text { documentation such as systems red-line drawings, equipment } \\
\text { identification, specifications, develop final punch lists, } \\
\text { nonconformance reports, and change control documents, has } \\
\text { been completed. }\end{array}$ & & & \\
\hline 2. & $\begin{array}{l}\text { Coordinate the new fire water line tie-in in order to minimize the } \\
\text { associated impacts to the nuclear facilities. }\end{array}$ & & & \\
\hline 3. & $\begin{array}{l}\text { Project documentation required for partial project transfer [e.g., quality } \\
\text { records, CC test results, vendor data, red-line drawings]. }\end{array}$ & & & \\
\hline 4. & Punch list items on Form 432.68, "Project Deficiency Status Report." & & & \\
\hline 5. & Construction site cleaned up. & & & \\
\hline 6. & Applicable regulatory certifications/notifications. & & & \\
\hline 7. & $\begin{array}{l}\text { List of deficiencies to be corrected before and after partial project } \\
\text { transfer, as listed on Form } 432.04 \text {, "Inspection and Project Transfer." }\end{array}$ & & & \\
\hline 8. & System and systems red-line as-built drawings. & & & \\
\hline 9. & $\begin{array}{l}\text { List of remaining project activities to be performed after the partial } \\
\text { project transfer [e.g., SO testing, life safety tie-ins, voice/data tie-ins/cut- } \\
\text { over, as-building, etc.] to prepare for final project transfer. }\end{array}$ & & & \\
\hline 10. & $\begin{array}{l}\text { The installation, commissioning, configuration, testing, and acceptance } \\
\text { of the telecommunication equipment will utilize the original equipment } \\
\text { manufacturer (OEM) test and acceptance procedures. Testing shall be } \\
\text { completed and accepted prior to cut-over of services. }\end{array}$ & & & \\
\hline 11. & $\begin{array}{l}\text { Occupancy Safety Review (can be part of partial and final inspection } \\
\text { walkthrough) conducted before SO testing or other remaining project } \\
\text { activities. Safety related items necessary for temporary occupancy have } \\
\text { been determined. }\end{array}$ & & & \\
\hline
\end{tabular}


MFC Fire Water Replacement Project Acceptance/Turnover Plan

Effective Date: 09/03/2014

Page: 7 of 8

Final Facility Transfer

- Construction of the new MFC Fire Water Replacement Project, which includes a 400,000 gallon tank, pumps, new fire water piping, and all associated systems.

The following readiness checklist will document readiness for final project transfer when completed.

\begin{tabular}{|c|c|c|c|c|}
\hline & \multirow{2}{*}{ Deliverable or Activity } & \multicolumn{3}{|c|}{ Completed } \\
\hline & & Yes & No & NA \\
\hline 1. & $\begin{array}{l}\text { SO testing performed and test results approved: } \\
\text { A. HVAC equipment i.e., air conditioning, air handler, } \\
\text { building management system, (HVAC), test and balance } \\
\text { (TAB) and integrated auto control system testing. } \\
\text { B. Fire alarm system. } \\
\text { C. Paging and evacuation systems. } \\
\text { D. Fire water pump controls. } \\
\text { E. Water tank level controls. } \\
\text { F. Fire suppression system. } \\
\text { G. Electrical commissioning tests. } \\
\text { H. Lighting control system. } \\
\text { Note: The SO testing may be performed concurrently with the } \\
\text { subcontractors CC testing. }\end{array}$ & & & \\
\hline 2. & $\begin{array}{l}\text { Updated safety documentation: } \\
\text { A. Hazard assessment if applicable. } \\
\text { B. Emergency preparedness plan. } \\
\text { C. Notification to the MFC fire protection engineer (FPE) } \\
\text { that, upon turnover (final transfer), the fire safety } \\
\text { assessment (FSA) will need to be developed within one } \\
\text { year of the project turnover. } \\
\text { D. Pre-incident plans. }\end{array}$ & & & \\
\hline & Remaining red-line as-built drawings. & & & \\
\hline & $\begin{array}{l}\text { BOP will determine which key/one-line essential drawings shall } \\
\text { be developed from the project red-lines prior to the final } \\
\text { turnover. }\end{array}$ & & & \\
\hline & $\begin{array}{l}\text { Submittal of project documents needed for operation (vendor } \\
\text { data, spare parts, preventative maintenance, etc.) to the system } \\
\text { engineer's organization. }\end{array}$ & & & \\
\hline
\end{tabular}


MFC Fire Water Replacement Project Acceptance/Turnover Plan Effective Date: 09/03/2014

Page: 8 of 8

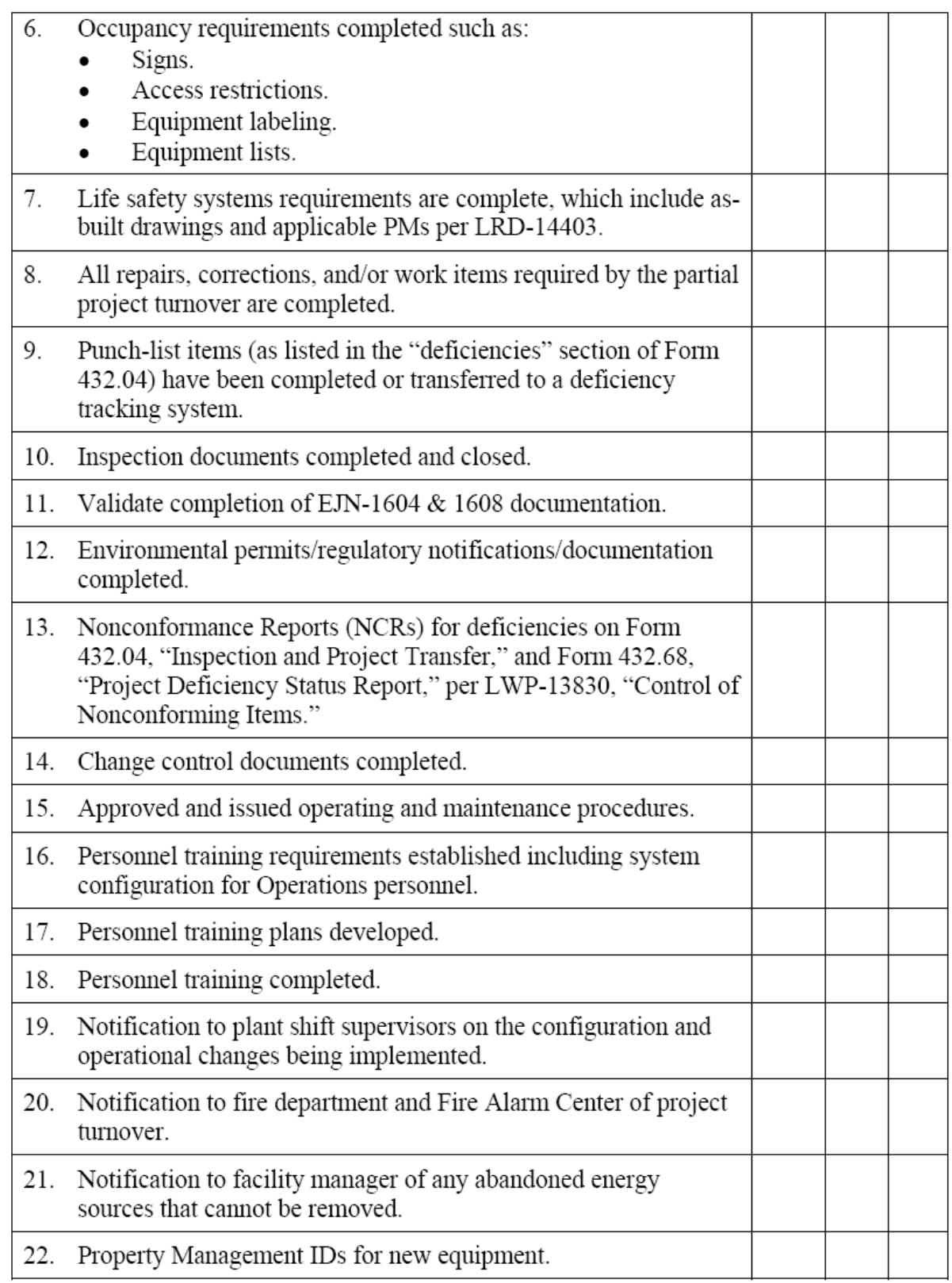




\section{Appendix I,}

\section{Executed Transition to Operations Final Turnover Checklist}

\begin{tabular}{|c|c|c|c|c|c|}
\hline \multirow{2}{*}{\multicolumn{2}{|c|}{ Deliverable or Activity }} & \multicolumn{3}{|c|}{ Completed } & \multirow[b]{2}{*}{ Comments } \\
\hline & & Yes & No & NA & \\
\hline 1. & $\begin{array}{l}\text { SO testing performed and test results approved: } \\
\text { A. HVAC equipment i.e., air conditioning, air handler, } \\
\text { building management system, (HVAC), test and } \\
\text { balance (TAB) and integrated auto control system } \\
\text { testing. } \\
\text { B. Fire alarm system. } \\
\text { C. Paging and evacuation systems. } \\
\text { D. Fire water pump controls. } \\
\text { E. Water tank level controls. } \\
\text { F. Fire suppression system. } \\
\text { G. Electrical commissioning tests. } \\
\text { H. Lighting control system. } \\
\text { Note: The SO testing may be performed concurrently with } \\
\text { the subcontractors CC testing. }\end{array}$ & $\begin{array}{l}\mathrm{D} \\
\mathrm{E} \\
\mathrm{F} \\
\mathrm{G}\end{array}$ & & $\mathrm{H}$ & $\begin{array}{l}\text { A) VDR } 532017 \\
\text { B) VDR } 528906 \\
\text { C) N/A - There were no paging or } \\
\text { evacuation systems as part of this } \\
\text { project. } \\
\text { D) VDR } 547420 \\
\text { E) VDR } 547420 \\
\text { F) VDR } 523731 \\
\text { G) VDR } 528254,542792 \\
\text { H) N/A - There was no lighting } \\
\text { control system as part of this project. }\end{array}$ \\
\hline 2. & $\begin{array}{l}\text { Updated safety documentation: } \\
\text { A. Hazard assessment if applicable. } \\
\text { B. Emergency preparedness plan. } \\
\text { C. Notification to the MFC fire protection engineer (FPE) } \\
\text { that, upon turnover (final transfer), the fire safety } \\
\text { assessment (FSA) will need to be developed within } \\
\text { one year of the project turnover. } \\
\text { D. Pre-incident plans. }\end{array}$ & $\mathrm{C}$ & & $\begin{array}{l}\text { A } \\
\text { B }\end{array}$ & $\begin{array}{l}\text { A) Not Applicable } \\
\text { B) Not Applicable } \\
\text { C) Email was sent to Brion Pearson } \\
\text { and Bruce Hendrix (MFC FPE) on } \\
\text { 5/18/16. } \\
\text { D) Fire Department does not maintain } \\
\text { pre-incident plans for Low Risk }\end{array}$ \\
\hline
\end{tabular}




\begin{tabular}{|c|c|c|c|}
\hline & & & $\begin{array}{l}\text { Facilities. Instead, they maintain } \\
\text { Quick Access Plans which has been } \\
\text { completed. }\end{array}$ \\
\hline 3. & Remaining red-line as-built drawings. & $\mathrm{X}$ & VDR-530703, 545247 \\
\hline 4. & $\begin{array}{l}\text { BOP will determine which key/one-line essential drawings } \\
\text { shall be developed from the project red-lines prior to the final } \\
\text { turnover. }\end{array}$ & $\mathrm{X}$ & $\begin{array}{l}\text { Drawings released into EDMS; } \\
\text { via eCR } 639484 \text { on 3/30/16. } \\
\text { via eCR's 639156, 639157, 639158, \& } \\
639159 \text { on 5/18/16. }\end{array}$ \\
\hline 5. & $\begin{array}{l}\text { Submittal of project documents needed for operation (vendor } \\
\text { data, spare parts, preventative maintenance, etc.) to the } \\
\text { system engineer's organization. }\end{array}$ & $\mathrm{X}$ & $\begin{array}{l}\text { See O\&M Manual } \\
\text { INL/EXT-16-38510. }\end{array}$ \\
\hline 6. & $\begin{array}{l}\text { Occupancy requirements completed such as: } \\
\text { - } \quad \text { Signs. } \\
\text { - } \quad \text { Access restrictions. } \\
\text { - } \quad \text { Equipment labeling. } \\
\text { - } \quad \text { Equipment lists. }\end{array}$ & $\mathrm{X}$ & $\begin{array}{l}\text { Walk-down conducted with } \\
\text { Operations on February 4, 2016, and } \\
\text { April 7, 2016. Acceptance } \\
\text { documented in the Final Transfer. }\end{array}$ \\
\hline 7. & $\begin{array}{l}\text { Life safety systems requirements are complete, which include } \\
\text { as-built drawings and applicable PMs per LRD-14403. }\end{array}$ & $\mathrm{X}$ & $\begin{array}{l}\text { MWO } 228412 \text { (PM) } \\
\text { VDR-523608 (As-built drawings) }\end{array}$ \\
\hline 8. & $\begin{array}{l}\text { All repairs, corrections, and/or work items required by the } \\
\text { partial project turnover are completed. }\end{array}$ & $\mathrm{X}$ & $\begin{array}{l}\text { Completed. Documented by the Final } \\
\text { Transfer. }\end{array}$ \\
\hline 9. & $\begin{array}{l}\text { Punch-list items (as listed in the "deficiencies" section of } \\
\text { Form 432.04) have been completed or transferred to a } \\
\text { deficiency tracking system. }\end{array}$ & & $\begin{array}{l}\text { Completed. Documented by the Final } \\
\text { Transfer. }\end{array}$ \\
\hline 10. & Inspection documents completed and closed. & $\mathrm{X}$ & $\begin{array}{l}\text { QA has signed off on the Inspection } \\
\text { Plans. }\end{array}$ \\
\hline 11. & Validate completion of EJN-XXX documentation. & $\mathrm{X}$ & $\begin{array}{l}1604 \text { and } 1608 \text { have been completed } \\
\text { through Final Transfer. }\end{array}$ \\
\hline
\end{tabular}




\begin{tabular}{|c|c|c|c|c|}
\hline & $\begin{array}{l}\text { Environmental permits/regulatory } \\
\text { notifications/documentation completed. }\end{array}$ & $\mathrm{X}$ & & See CCN 238230. \\
\hline 13. & $\begin{array}{l}\text { Nonconformance Reports (NCRs) for deficiencies on Form } \\
\text { 432.04, “Inspection and Project Transfer,” and Form 432.68, } \\
\text { "Project Deficiency Status Report,” per LWP-13830, } \\
\text { "Control of Nonconforming Items.” }\end{array}$ & & $\mathrm{X}$ & There were no NCRs. \\
\hline 14. & Change control documents completed. & $\mathrm{X}$ & & $\begin{array}{l}\text { All CFP's have been finalized. No } \\
\text { BCPs are in progress. }\end{array}$ \\
\hline 15. & Approved and issued operating and maintenance procedures. & $\mathrm{X}$ & & $\begin{array}{l}\text { See O\&M Manual } \\
\text { INL/EXT-16-38510. }\end{array}$ \\
\hline 16. & $\begin{array}{l}\text { Personnel training requirements established including system } \\
\text { configuration for Operations personnel. }\end{array}$ & $\mathrm{X}$ & & $\begin{array}{l}\text { Training has been completed. } \\
\text { Documented in TRAIN (qualification } \\
\text { QNMFCNBS Rev 2). }\end{array}$ \\
\hline 17. & Personnel training plans developed. & $\mathrm{X}$ & & $\begin{array}{l}\text { Training has been completed. } \\
\text { Documented in TRAIN (qualification } \\
\text { QNMFCNBS Rev 2). }\end{array}$ \\
\hline 18. & Personnel training completed. & $\mathrm{X}$ & & $\begin{array}{l}\text { Training has been completed. } \\
\text { Documented in TRAIN (training } \\
\text { roster AFBSO0001). }\end{array}$ \\
\hline 19. & $\begin{array}{l}\text { Notification to plant shift supervisors on the configuration } \\
\text { and operational changes being implemented. }\end{array}$ & $\mathrm{X}$ & & $\begin{array}{l}\text { Plant shift supervisor was part of each } \\
\text { partial and final turnover walk-down } \\
\text { and the Facility Manager signed the } \\
\text { partial and final transfers. }\end{array}$ \\
\hline 20. & $\begin{array}{l}\text { Notification to fire department and Fire Alarm Center of } \\
\text { project turnover. }\end{array}$ & $\mathrm{X}$ & & $\begin{array}{l}\text { Fire Department representatives } \\
\text { participated in the walk-down. } \\
\text { Notifications were sent via email to } \\
\text { the Fire Department Battalion Chief } \\
\text { and the Fire Alarm Center on May 23, } \\
2016 \text {. }\end{array}$ \\
\hline
\end{tabular}




\begin{tabular}{|l|l|l|l|}
\hline 21. $\begin{array}{l}\text { Notification to facility manager of any abandoned energy } \\
\text { sources that cannot be removed. }\end{array}$ & X & $\begin{array}{l}\text { N/A - There were no abandoned } \\
\text { energy sources. }\end{array}$ \\
\hline 22. Property Management IDs for new equipment. & $\begin{array}{l}\text { N/A - There were no property } \\
\text { management ID's required new } \\
\text { equipment. All items were real } \\
\text { property. }\end{array}$ \\
\hline
\end{tabular}




\section{Appendix J,}

\section{Idaho Department of Environmental Quality Final Project Approval}

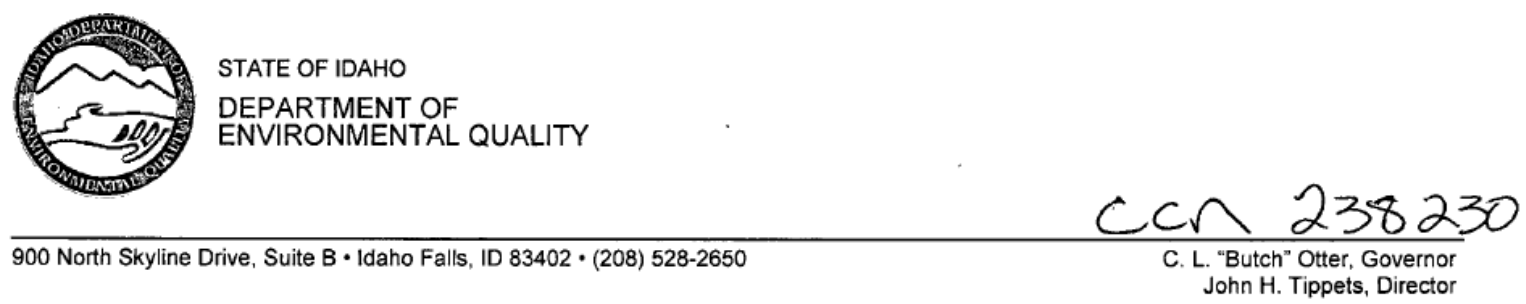

May 4, 2016

Scott Lee, Manager

Idaho National Laboratory

Regulatory and Monitoring Services

PO Box 1625

Idaho Falls, ID 83415

Re: TREAT Water Line Extension and New MIOX Treatment System and Storage Tank for PWS\# 6060036, Drinking Water, DEQ\# 15-01-12

Dear Mr. Lee:

We have reviewed the as-built plans and specifications along with the O\&M manual for the TREAT Water Line Extension and New MIOX Treatment System and Storage Tank for PWS\# 6060036. The plans and specifications meet State standards and the system appears to be operating as intended. This submission satisfies the requirements set forth in Idaho Code Section 39-118.

The submitted as-built plans and specifications will be kept on file at this office. Please reference DEQ No 15-01-12 when submitting any future correspondence related to this project. If you have any questions regarding this letter or if we can be of further assistance, please call me at (208) 528-2650.

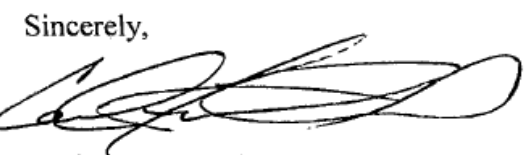

Carlin Feisthamel, P.E.

Water Quality Engineer

Idaho Falls Regional Office

c: $\quad$ Greg Eager, Regional Engineering Manager, DEQ-Idaho Falls Rochelle Mason, Drinking Water Analyst, DEQ-Idaho Falls 